



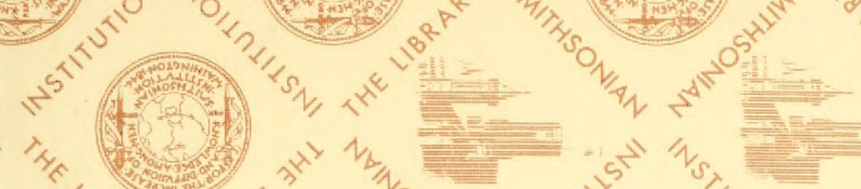

सेक

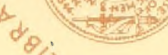

IIIf

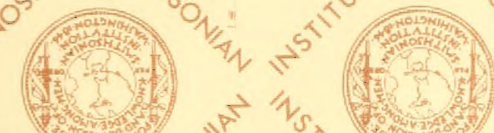

$\mathrm{L}^{\circ}$ iil
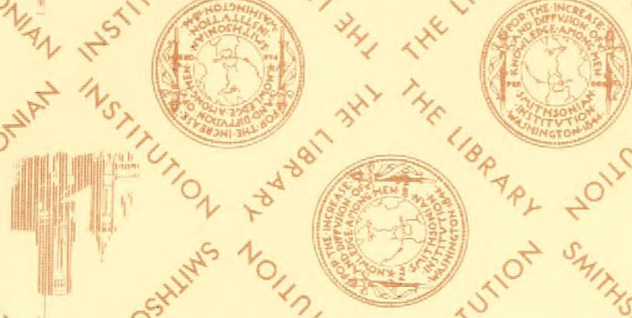

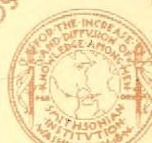
(ris)

告
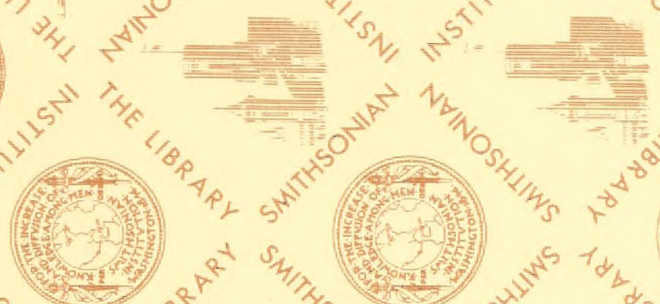

A.
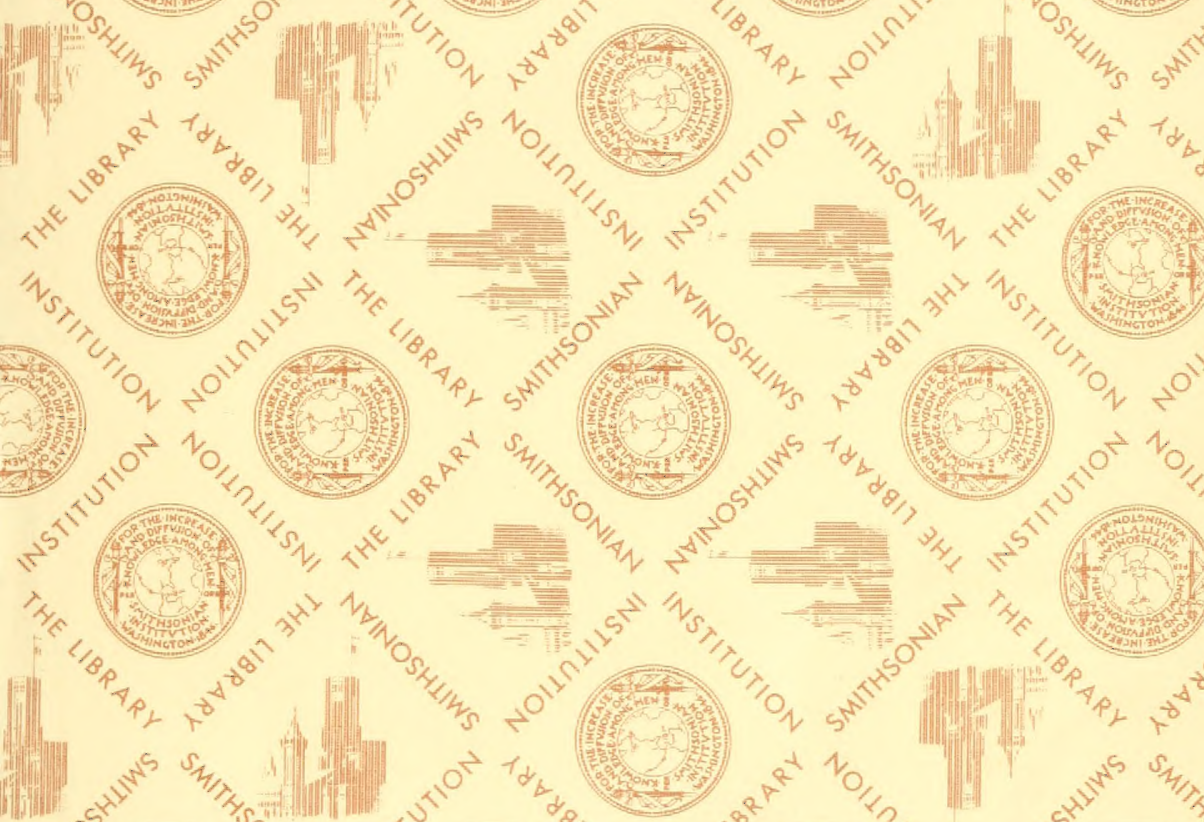

$</ s$

$\frac{4}{5}$
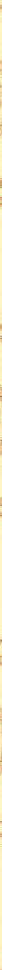

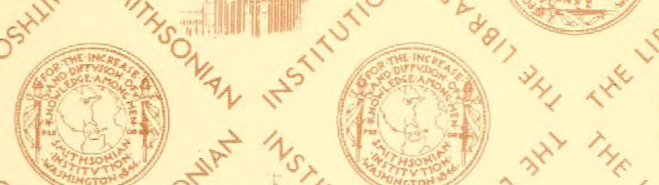

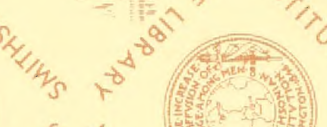

int

$f^{2}, e^{2}$

$\mathrm{O}_{1}+\mathrm{O}^{\prime}$

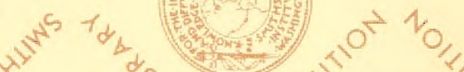

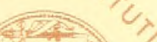

find

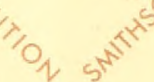

$p^{2}+1 / 2$

Lififin
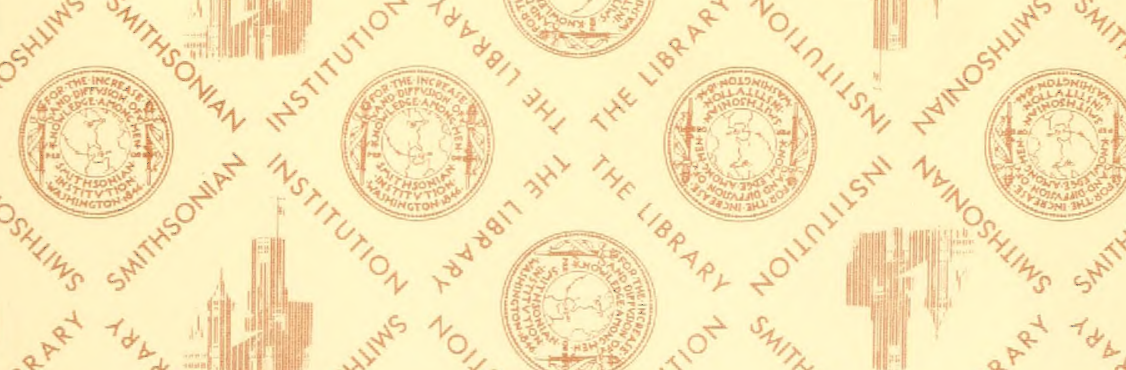

$D-12$ 



\section{Sf}

BULLETIN No. 27.

(B. A. I. 155.)

T47U. S. DEPARTMENT OF AGRICULTURE, Mamm. BUREAU OF ANIMAL INDUSTRY.

D. E. SALMON, D. V. M., Chief.

\section{INFORMATION}

\section{TIIE ANGORA GOAT.}

BY

GEORGE FAYETTE THOMPSON,

Editorial Clerk, Burean of Animal Industry.

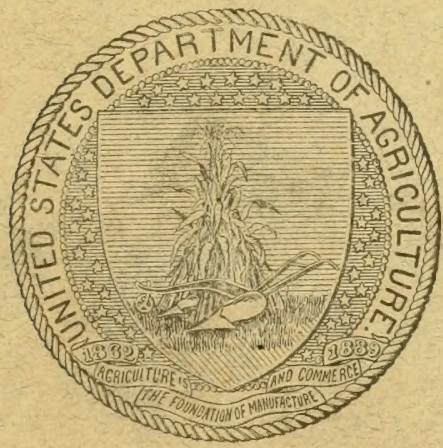

WASHINGTON:

GOVERNMENT PRINTING OFFICE.

1901. 




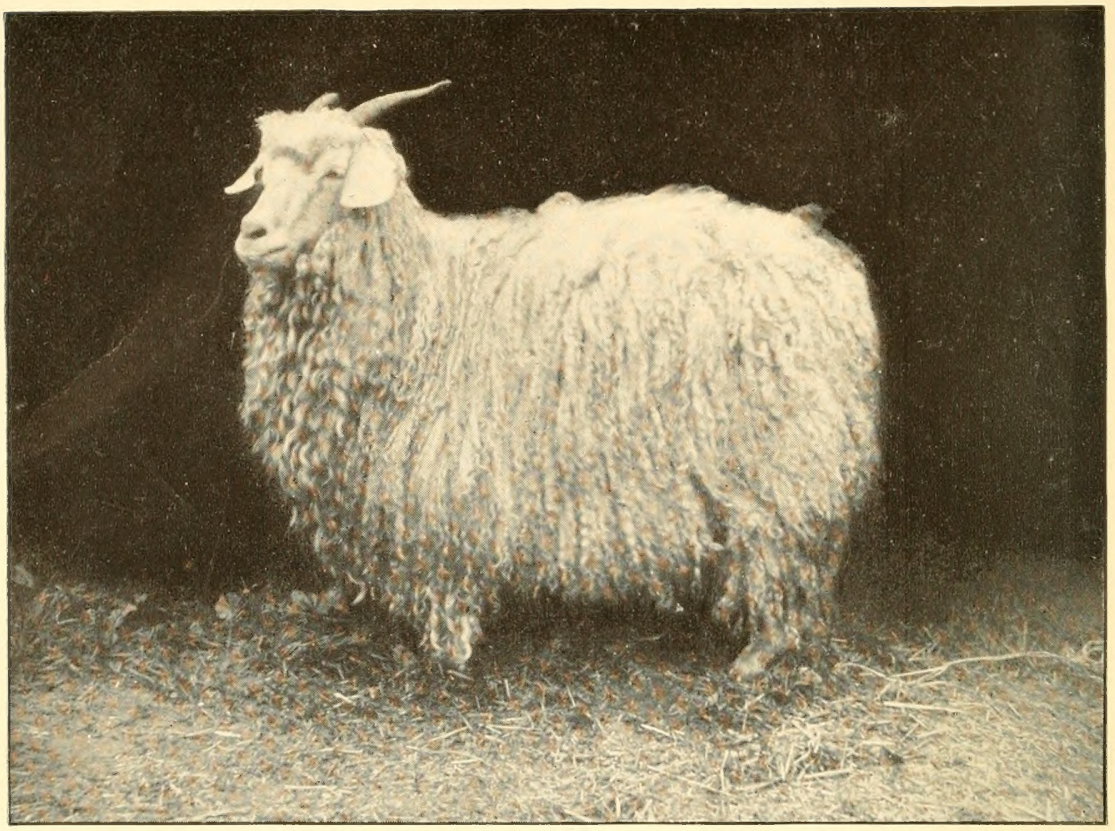

Fig. 1. - Madam Ladysmith, Three Years Old. Fleece, 8 Pounds. (Photograph furnished by C. P. Bailey \& Sons Company, San Jose, Cal.)

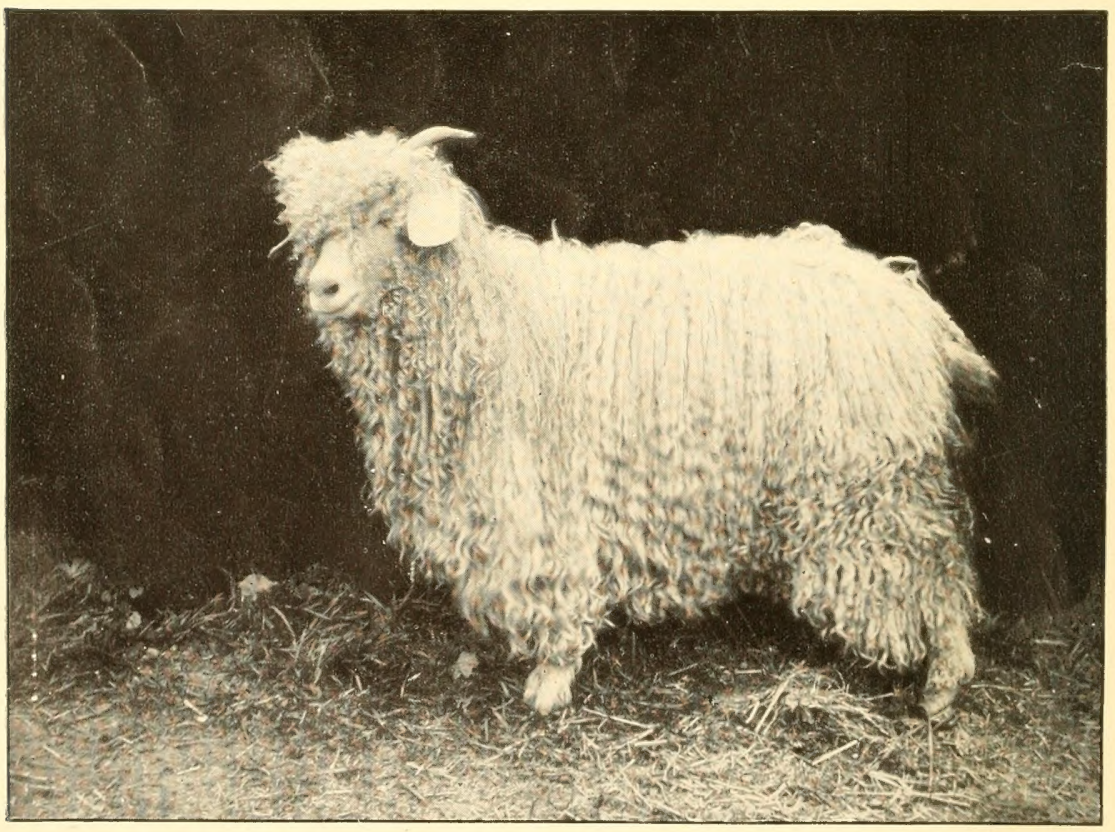

Fig. 2.-Princess Monterey, Ten Months Old. Fleece, $4 \frac{1}{\text { Pounds. }}$ (Photograph furnished by C. P. Bailey \& Sons Company, San Jose, Cal.) 
U. S. DEPARTMENT OF AGRICULTURE, BUREAU OF ANIMAL INDUSTRY.

D. E. SAlMON, D. V. M., Chief.

\section{INFORMATION}

\section{THE ANGORA GOAT\%}

$\mathrm{BI}$

\section{GEORGE FAYETTE THOMPSON,}

Editorial Clerk, Bureau of Animal Industry.

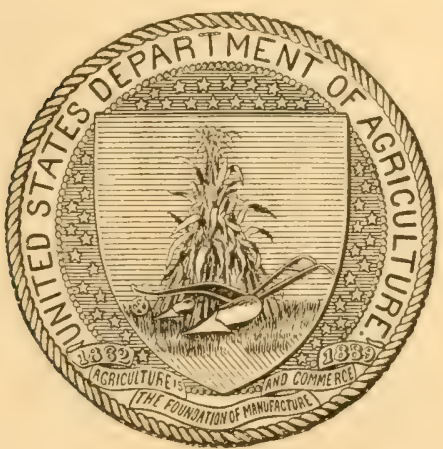

WASHINGTON:

GOVERNMENT PRINTING OFFICE, 


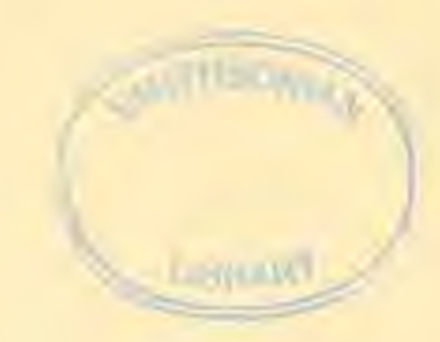




\title{
LETTER OF TRANSWITTTAL.
}

\author{
U. S. Department of Agriculiture. \\ Bureau of Animal Industry. \\ Washington, D. C., November 23, 1900.
}

SIr: I have the honor to tramsmit herewith the manumeript of an article entitled "Information conecrning the Angorat goat," hy Mr. Georese Fayette Thompson, editorial clerk of this Bureatu. There is much interest in this industry, and the Department receives thousands of letters of inguiry conerning Angora goats. An effort is made in this manuscript to treat all the topises that have been the subjerets of these letters of inquiry.

It is estimated that there are ahout tor). 100 . Angora goats in the Tnited States. and that on ammual production of mohair is orer a million pounds. It appeass, therefore, that the industry should rexeire some attention from this Department, at least in so far as the collection and dissemination of information may be concerned, and I recommend that this article be published as Bulletin No. 2̌ of the Bureau of Animal Industry.

Respectfully,

D. E. SaLiton, Chief of Bureau.

Hon. JAMES WILSON,

Secretury. 



\section{CONTENTS.}

Preliminary remark

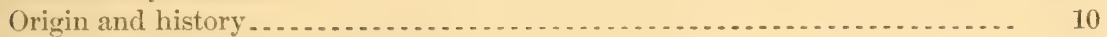

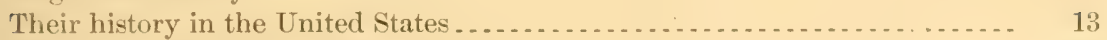

Dew ription of the Angura goat . . . . . . . . . . . . . . . . . . . . . . . . . 21

Names of the breed, the sexes, and the meat ........................ 24

Name of the breed ....................................... 24

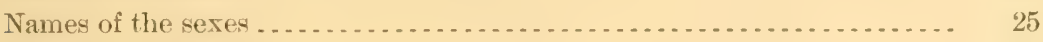

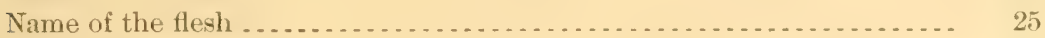

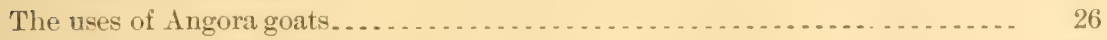

Browsing and pasturage ......................................... 20

Ahility to dear hrush land............................. 26

Browsing supplements feeding .............................. 33

Browsing adds game flavor............................... 33

Common goats as brush destroyers ........................ 33

Preserving brush land for browsing........................ 33

Grass and weeds as pasturage ............................ 34

Pasturing with other stock ................................. 35

Number of grats to an acre.............................. 36

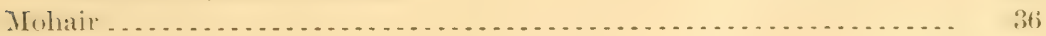

Quality of the fiber......................................... 36

Influence of age and blood on fiber ........................ 39

The weight and length of fleece........................ 39

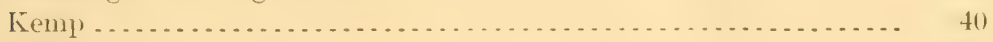

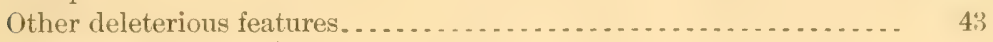

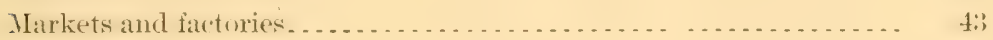

I'roduction ......................................... 4

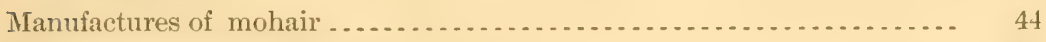

The meat and the matrets . . . . . . . . . . . . . . . . . .

The meat. . . .

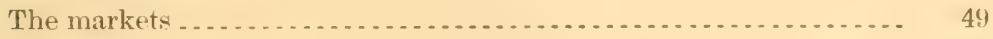

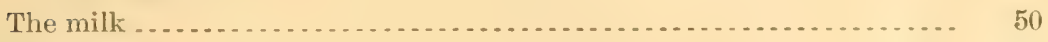

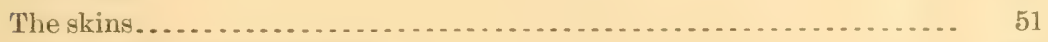

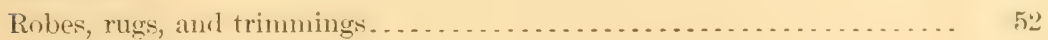

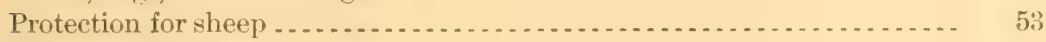

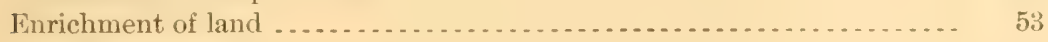

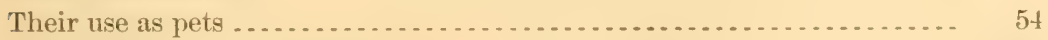

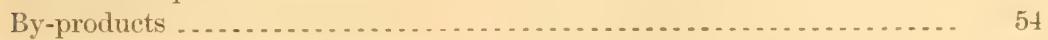

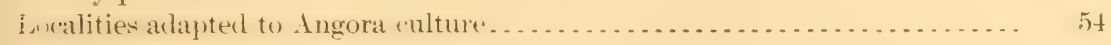

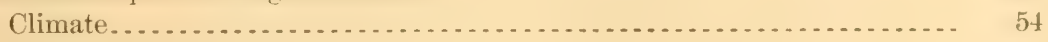

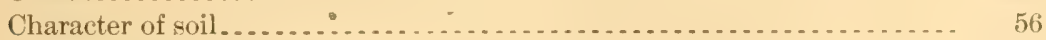

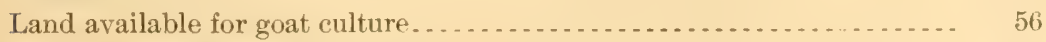

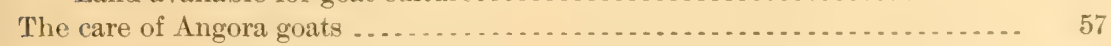

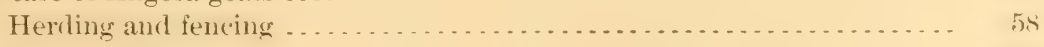

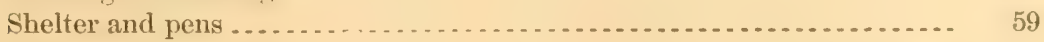


The care of Angora goats-Continued. Page.

Feeding . . . . . . . . . . . . . .

Salting - . . .

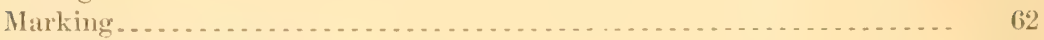

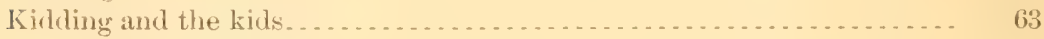

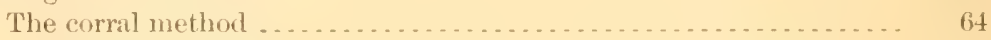

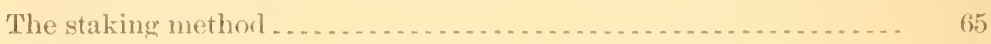

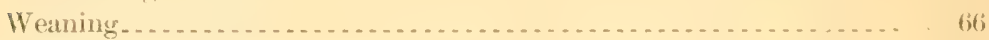

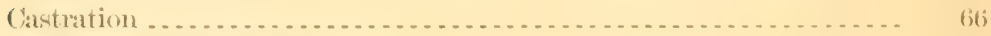

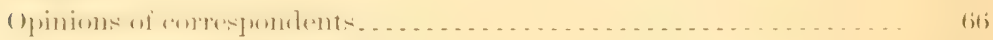

The building up and management of a flock of Angora goats............ 68

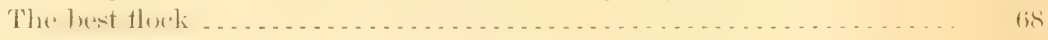

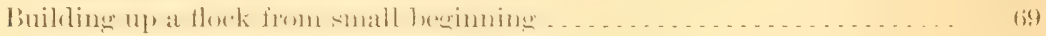

Building up a flock by crossing upon the common goat ............. 69

Proper age for breeding.................................... 70

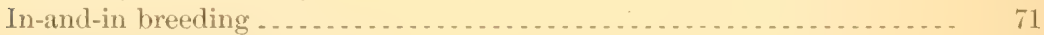

Management of the buck ..................................... 74

Number of kids . . . . . . . . . . . . . . . . . . .

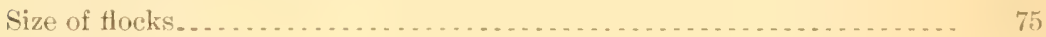

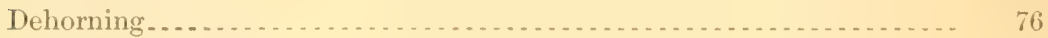

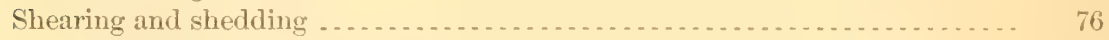

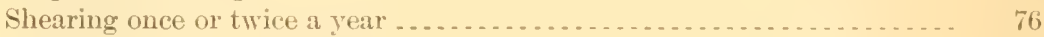

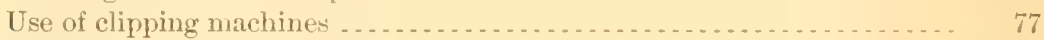

Care of the fleece after shearing ... . . . . . . . . .

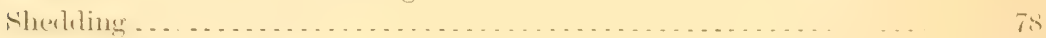

Diseases and other enemies . . . . . . . . . . . . . . . . . . . . . . . . . . 79

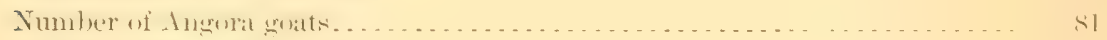

In the United States. . . . . . . . . . . . . . . . . . . . . . . . .

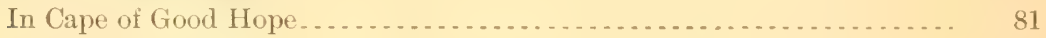

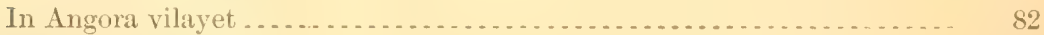

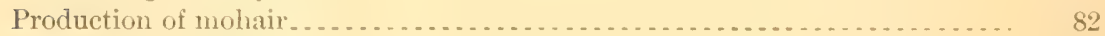

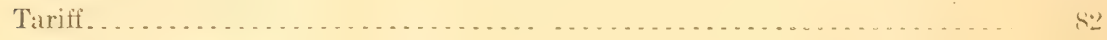

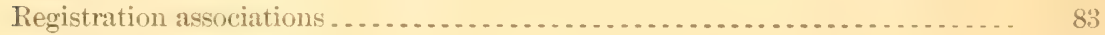

Literature consulted ............................................ 83 


\section{ILIUSTRATIONS.}

Plates.

Page.

Frontispiece. Fig. 1, Madam Ladysmith, three years old, fleece 8 pounds; fig. 2, Princess Monterey, ten months old, fleece $4 \frac{1}{2}$ pounds.

Plate I. Fig. 1, Angora buck (Davis importation, 1849); fig. 2, Angora doe

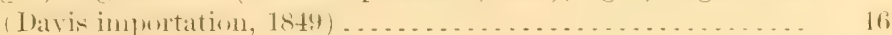

II. Brush land "before goating" ............................ 32

III. Brush land "during goating" after twelve months. . . . . . . . . . 32

IV. Brush lamel "after genating" two years. . . . . . . . . . . . . . . 32

V. Samples of mohair.................................. 40

VI. Does twenty-one months old; fleece of nine months' growth .... 40

VII. Fig. 1, Angora buck "Pasha;" fig. 2, a yearling Angora in Cape Colony ......................................... 48

VIII. Angora goats showing fleeces of seven months' growth ........ 48

IX. Angora goats in yard; also shows one kind of suitable fence..... 56

X. Angora goat ranch of H. T. Fuchs....................... 56

XI. Flock of Angora goats at straw stack . . . . . . . . . . . . . . . . . . 64

XII. Fig. 1, Angora kids; fig. 2, going to pasture (separation of does from kide ly means of hridge) . . . . . . . . . . . . . . . . . .

XIII. Angora goats in rocky pasture....................... 72

XIV. Angoral guats in pasture...........................

XV. Angora goats in pasture ............................ 80

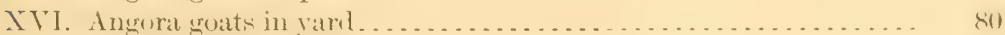

XVII. Fig. 1, a yearling Angora; fig. 2, shearing Angoras........... 80

TExt Figure.

Frc. 1, diagram showing age by teeth.............................. 



\section{INFORMATION CONCERNING THE ANGORA GOAT'}

\section{PRELIMINAIRY REMARKS.}

The goat has accompanied civilization into all parts of our countrynot numerously, but persistently. He is everywhere, and is well known. There are very few people who have not seen a goat, and there are fewer still, no doubt, who hare seen many goats. The comic writers, playing upon his peculiar habits, have brought him into disrepute, although these habits, to a large extent, are such as are recommending him for special faror at this time. His fame is as a denizen of vacant lots and back alleys, subsisting upon anything or nothing, and a foe to everything. So far as the general public is concerned, he has not been reckoned with as a useful animal and has been tolerated only as a pet for children.

During more recent year's a great interest has been awakened in the goat, and it now seems that he is about to receive the consideration that is due bim. One of the causes contributing to this awakening was an article in the Yearbook of this Department for 1898, entitled "Keeping goats for profit," by Capt. Almont Barnes, of the Division of Statistics of this Department. The information which this article contained was widely disseminated. The Yearhook was distributed to the extent of half a million copies, and, besides, in order to meet the growing demand, the article was reprinted separately and mailed to many thousands of inquirer's at the Department for information on the subject of goats; and not alone the agricultural paper's, but the daily press as well, took up the matter and exploited the good points of the goat industry. The article set forth, among other things, the great value of the goatskins which we import annually, and how we ourselves might easily produce them; the usefulness of the carreass for food, especially of the Angora hreed; the exceedingly small expense involved in raising the animal, owing to his habits of feeding upon that regetation which is in greatest abundance and which other ruminants refuse; the million of acres of land in the United States that might be made available for goat raising which otherwise would remain, as heretofore, unemployed.

The result of this wide distribution soon developed the fact that the goat was present in the United States in larger number's than was supposed. This is especially true of the Angora breed; in fact, the number of common goats in the United States is less than 50,000. Although 
rery little has been said or written about Angora goats during the last forty your, they have heen extensirely hred in the Western States and Territories, experially in Texas, New Mexien, Nevada, Florida, California, and Oregon. In a general sense, all those animals which are a cross in any degree of the Angora goat are considered as Angoras, for the Angora and the common goat readily cross, and the latter frequently becomen the foundation stock of a good flock of flecee-bearing animals.

It is the purpose of this article to deal with the Angora goat only, and the effort is made to answer such questions as have been received by the Bureau from all parts of the country. These answers are hased upon the experiences of those who have raised them, some of whom have been in the business forty years and more. Differences of opinion are found to exist on several important points, where each contestant appears to ocoupr plausible premises; but this is not at all strange when the history of the Angora goat is considered, for it is not certain that all of the animals imported as purebreds were pure; indeed, it is held by some of our leading breeders that there is no longer in Turkey or elsewhere any such thing as a purebred Angora goat. Besides, there has been no general register for Angora stock in the United States until within a year or two, and each breeder has been at liberty to judge points for himself. If a general Angora register had heen established thirty or forty year's ago, the industry would now be conducted upon somewhat definite lines, and most of the questions now arising as to points in breeding would have been settled. In this romection it should be stated that ( $\because$ P. Bailey \& soms ('ompany, of San Jose, Cal., have kept a private register of their goats since 1867 . hut there appears to be no other similar record.

\section{ORIGIN AND HISTORY.}

The purpose of this paper is to give prominence to those phases of the Angora goat industry that are of practical importance; therefore a brief suace only will be deroted to the history of the breed.

Naturalists generally agree that there are about ten species of wild goats, all confined to Europer and the Himalayas of Asia. These are divided into two groups, as follows:

I. The iludes.-These, according to Hayes, have, as a distinctive characteristic, horns " flat in front, with a horizontal triangular section, furnished with large transversal knots."

II. Gouts proper.-These, according to Hayes, have horns "compressed and earinated in front," and, aceording to Wood, "may be distinguished from the ibex and the sheep by the peculiar formation of the horns, which are compressed and rounded behind and furnished with a well-developed keel in front." 
The seroud goloup is subdirided into two subsperies-- ('upmer firl-

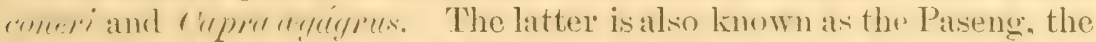
Bezoal gant, or wild goat of Persia, and is generally arepted as the goat from which the Angora is descended through Cuppur lirens, which is elaimed to be the origin of all the common breeds of goats.

As to the parent of the Angora stork, there is a difference of opinion between the two best-known writers on the subject-. Iohn I. Mayes, athor of the Ingerat (ioat, ete. (1582), and s. ( . Crombright schreiner, anthor of 'The Angora (ioat (1Sts). 'The one takes the

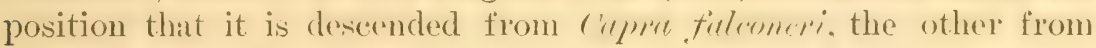
Cupra agrerns. Owing to the additional information which has been olotained sinces the appearance of Hayes's hook and which is embodied in Schreiner"s work, there can hardly remain a doubt of the correctness of the contention that the Angolar goat descended from rimmer arfurifres.

Fichreiner, who has madr exteusive research, has described these two subspecies as follows:

riprofulconeri hats a beard which extends from the chin to the shoulders and chest, and long spirally twisterl horns, the twist heing outwand from the base. The males, when old, become whitish all over. The ewes have at heard contined to the chin, and small horns with a slight spiral twist. It is a native of the Western Himalarat, northern Afghanistan, and possibly of Persia; it is also found generally in (ashmere and on the Tibetan side of the Himalayas. Fossil remains show that it is one of the oldest types of goats.

crum a ayagrus ${ }^{1}$ is chiefly remarkable for its enormous horns, which are larger proportionally than in any other ruminant animal; they approximate the triangular in form, transversely rigid, and are bent backward as in the romestic varieties, leeing scimitar-like in shape of curve, and having no spiral twist. Large horns of ceforce argugins meatsure 40 inches along the curve, but a length of upwart of 52 ? inches, with a basal girth of 7 inches, has leeen recorded. It stands sume what higher than any of the domesticaterl varieties of the goat (an adult male stowd 37 inches at the withers), from which it further differs in its short and powerful neck, its stouter limbs, and slender boily. In the female the horns are exceedingly dininutive or are altugether wanting. The fur, which over the greater part of the buty is short, is of a grayish brown color, with a black line running along the entire length of the back, while the under surface of the neck and the bearl, which is present in both sexes, are of a lowwn color. In the winter coat the hair on the neck and shoulders is rather longer than elsewhere, and in the sanc season, in the colder part of the animal's hathitat, at coat of woolly fur is developed beneath the hair.

${ }^{1}$ There is evidence that in classic times this goat was widely distributer wore the (irecian Archipelago, although in Europe it is now found only in Crete, the islanet of Antemelo, in the Cyclades, and perhals also in Guire to the northeast of Fulmat. Eastward it is found in the hills and mountains of Asia Minor, being especially common in the Taurus range, and it extends thence through Persia into Baluchistan, Sind, and Ifyhanistan. In India its range does not extend beyond the wentern side of Sind. It is found in Sind and Baluchistan in hills a little above the sea level; in the momntains of Persia it areends to an elevation of 11,000 feet $t 012,000$ feect. Schreiner. 
The Angora breed of goats originated in the vilayet of Angora, in Asia Minor, but it is not known when this was. Some have ventured to say that it was 2,400 years ago. There is pretty strong eridence which goes to show that they were a distinctive breed when Moses was leading the Isratelites out of Eerpt. Goats" hair was spun by the Israelites for "urtanins and other purposes for use in the temple. In the story recorded in I Sammel (chapter 19) of the artifice of Michal in deceiving the messengers of saul hy placing an image in the hed in place of Darid and giving it a pillow of goats" hair, is helieved by Pennant to refer to a pillow made of the Angora fleece.

The city Angor:a, or Enguri, the capital city of the rilayet of Angori, is the ancient Ancyra, and is located alout 220 miles south by southeast from Constantinople. Angora was the seat of one of the earliest Christian churches. and was probably established by the Apostle Paul. The province is momtainous to a considerable extent and furrowed by deep valleys. It is about zonou feet ahove the level of the sea. Of the climate Mr. H. A. ('umberbateh. British consul at Angora (1895), and quoted by Schreiner, says:

The elinate is extreme. In the monthe of January and February the thermometer will nuark a mininum of $10^{\circ} \mathrm{F}$. for several days at a time, reach as far an $\left(0^{\circ} \mathrm{F}\right.$, whilst in June and July the maximum readings of $85^{\circ} \mathrm{F}$. are maintained day after day, with little or no rain. The country is covered with snow in the winter, rain and snow falling frequently. In $189+$ the total rainfall at Ingora was s.12 inches, but that wat an exerptimally dry season. For the first six months of 1895 the rainfall was 10.10) inches, which is somewhat above the average; the heaviest rainfa!! in twenty-four hours having been 1.20 inches.

It was here that this famous goat reached its perfection-and such a state of perfection as has not ret heen reached by the goats of either the Cape of Crood IIope or the U'nited States. That the altitude, the soil, or the climatr, or all of them together, had much influence in producing this flecere-bearing goat is supported by strong evidence. Dr. John Bathman and the Encrelopedia Britamnica both state that the fineness of the hair of the Angora goat may perhaps be ascribed to some peculiarity in the atmosphere, "for it is remarkable that the (ats. dogs, sheep, and other animals of the comntry are to a certain extent affected in the same way as the goats." The same opinion was

${ }^{1}$ Take ye from among you an offering unto the Lord: whosoever is of a willing heart. let him bring it, an offering of the Lord; gold, and silver, and hrass, and blue, and purple, and scarlet, and fine linen, and goats' hair.-Exodus xxxy, 5, 6.

And every man, with whom was found blue, and purple, and scarlet, and fine linen, and goats' hair, and red skins of rams, and badgers' skins, brought them.Exodus xxxv, 23.

And all the women whose heart stirred them up in wisdom spun goats' hair.Exodus xxxv, 26.

And he mate curtains of goats' hair for the tent orer the tabernacle: eleven curtaing he made them. The length of one eurtain was thirty eubits, and four cubits was the hreadth of one "urtain: the eleven curtains were of one size.-Exodus xxxri, 14, 15. 
expressed by Captain Conolly. quoted by southey (1s+8): "Tt is remarkable that wherever these goats exist the "ats and greyhounds have long silky hair also-the "ats all over their hodies, the greyhounds chiefly on their cars and tails." These statements lead Schreiner to the conclusion that the atmosphere is the chief factor. Ile says: "At any rate, there seems to be no doubt that a limited and comparatively well-defined region around the town of Angora possesses in a degree unapproached clsewhere in Asia Minor, and probahly in the world, those conditions favorable to the development of the soft, silky, lustrous white mohair goat." 'Too much eredit must not he given to the atmosphere of Angora in the production of mohair. That it has a marked influence on animals anywhere is generally accepted. The experience of the Angora breeders of the Cape of Crood IIope and the United States shows that, with the best animals, a fleece equal to any produced by Turkey may be obtained. There are other and stronger reasons why the mohatir of these two comntries is not equal to that of Angora province, chief among which is the adulteration of the blood. Besides, the breeder's of this country have learned that the feed of the animal has a telling influence on the quality of the mohair in the same way that it has a pronounced effect upon the meat.

Mr. Henry O. Bims, who had about twenty years of experience with these goats in the vilayet of Angora, says the pure animals were ahout bred out in 1863. The reason for this was the extensive cross. ing with the common Kurd goat, reference to which has alreary been made. As early as 1839 there ceased to be a demand for the spun yarn of Asia Minor, owing to the fact that Europe could spin the yarn at much less cost; but there was a European demand for the raw hair which exceeded the supply. This condition of things led to complications and a mixture of breeds from which the mohair world has not yet recovered. There can hardly remain a doubt, however, that, with the recent renewed interest in the industry, and with the intelligence that the breeders will bring to hear, the Angora goat industry will soon be placed on the highest plane.

THEIR HISTORY IN THE UNITED STATES.

Thie history of the Angora groat in the United States has been marred hy the carelessness or indifference of occasional writers for the press who have been often inaceurate as to dates or facts. and also by others whose interests have doubtless led them into exaggerations. The real facts of its history in the United States, however, are so few and so simple as to prompt that venerable breeder, William M. Landrum, to say that they would make but a very small book.

During the Administration of President Polk, the Sultan of Turkey requested of him that he recommend some one who would experiment in the culture of cotton in 'Turkey. Accordingly, Dr. James 
B. Daris, of Columbia. A. (C.. was recommended, and he received the appointment. The work done by Dr. Davis appeared to he highly gratifying to the Sultan, and so, upon his return, in 18t?, the Sultan, desiring to reciprocate the courtesy of the President, presented him with nine of the choicest goats in his dominion. Col. Richard Peter's, writing in 1si6, ways of these animals: "These doubtless were selected from the herels of $\Lambda$ ngora, a distriet of eountry lying among the Taurus Mountains, which traverse Asiatic Turkey, and which derives its name from its principal city situated about 200 miles a ast of (Constantinople." It does not seem, therefore, that I)r. Divis encomutered any great difficulty in securing this first importation of Angora goats into this country; but the following extract from the (ountry Gentleman of 1sow, somewhat romantic and a little exciting. was signed hy one Richard Allen, of Tennessee. The article, in full, shows that he was probably of that class of writers of history whose personal interests were to be subserved:

It may not be out of place in this connection to remark that great credit is due to Dr. Davis, of south (arolina, for the enterprise he exhihitesl in the introuluetion of the suat to this country. If was at the time in the employ of the Turkish covernment, at a salary of $\$ 15,000$, engaged in experinents num the growing of cotton in the Sultan's dominions. He went ont upon the rexommembation of Presislent Polk, to whom an applieation was male ly the Turkish frovermment for the serviese of some competent southern gentleman familiar with wotton culture. While there hes determined to procure the enoat from its native wilsk. The story of the jommey would be too tedious for my brief letter, and I will merely ardel that, with an expensivendfit

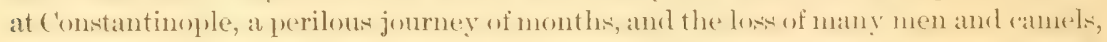

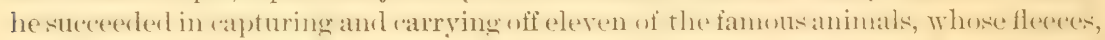
in the shape of shawls, are so highly prized and coveted hy the laties of all civilized nations and for which prices almost startling have been paid by the wealthy.

Such a tale of fortitude and determination, added to the information in another paragraph in the same letter which stated that the entire yield of the particular flock about which he was then writing had bern engaged in the city of New York at \$sis.n per pound. from which point it was to be shipped to Paisley. Scotland, for manufacture into the shawls mentioned above, no doubt assisted in the sale of goats at $\$ 1,000$ each.

In 1s6\%. Hon. (reorge A. Porter, of Baltimore, himself a breeder of Angoras, wrote to Mr. Dichl that, while occupying the post of United States consul at Constantinople. he " procured and shipped for Dr. Davis the first of these goats that were ever hrought to this aountry." Just how much Mr. Porter was areting upon the courtery of the Sultan it is difficult to ascertain.

Of the nine Angoras imported by Dr. Davis, seren were does and two were bucks. Bexides these, aceording to Colonel Peters, there came in the same lot one purehred Tilnet doe, several head of crosices hetween the Angoral and Tibet goats, and quite a number of grade does bred from the common short-haired ewes of the country and his Angora bucks. I'late I shows a pair of the Angorats imported hy Dr. 
Davis. 'The first is a buek, wrighing 155 pounds and calrying" a flecere of 7 pounds; the second is a doe, weighing 10.. pounds. arrying a Heece of $4 \frac{1}{2}$ pounds. These pictures appeared in the Country Gentleman in 1856 and were furnished that paper by Col. Richard Peters. who was at that time the owner of the goats. Dr. Davis, not heing familiar with goats, thought these were the famous Cashmere goats which fumished the fiber for the costly Cashmere shaw, and they were called Cashmere goats for many years after their introduction into the United states. The records show that as late as 1S61 Mr. William M. Landrum, the veteran breeder of Angoras, was awarded a silver goblet and 825 in "ash for the introduction of the first Cashmeres [Angoras] into California. Hon. Israel s. Diehl. writing on "The Croat" in the Ammual Report of this Department for 1 s6ris, grives deseriptions of different varieties of Angoras in Asia Ninor, among which was one variety which might rery easily be mistaken for the Cashmere. He says:

There is also a second or other variety of Angora, or shawl, goat besides those generally described. This goat has an unchanging outer cover of long, coarse hair, between the roots of which comes in winter an undercoat of downy wool that is naturally thrown off in spring or is carefully comber out for use. I remarkably fine species of this breed exists throughout the areal to whieh the white-hairesl gant is limiterl, and similar hreeds prevail all over the highlands of Turkish and Persian Armenia, Koordistan, and at Kirman; and, although some tlocks yield finer flewers than others, it is called the same wool or unler down as the wowl of cashmere and Tibet, and samples of the worl of the Tibetan and the double-worled groat of the banks of the Euxine show them to be but varieties of the same species.

This goat is of a larger size than those of the nore southern Turkish provinees and its wool finer, and is the variety probably introduced hy Dr. Davis from Asia Minor as the Cashmere, and now erroneonsly solled throughout the comntry, as all the importations of this country, as far as we can learn, were shippert from ports on the Mediterranean or constantinople, several thousand miles from Cashmere or Tihest, through inhompitable and almost untraveled countries for Europeans, which wow fir to prove the so-called "Cashmere goat" to be the Angora.

Mr. Diehl, in the same article mentioned abore. describes the Cashmere goat. The difference between it and the Angora of our country will be seen to be distinct. The similarity of the variety of Angorat described above and the Cashmere is marked, especially in respert of the downy undercoat. His description of the Cashmere is as follows:

This variety of the wool-bearing or shawl goat, as it is often callest, is sprearl ower Tibet, Northern Intia, and the regions to the east of the (aspian Fea. It is somewhat smaller than the common and Angora goat. It has straight, romml, perinted horns, penrlent ears; is covered with straight and falling long, fint, flat, silky hair, with an undercoat in winter of a delicate greenish wool, of but 2 to 3 ounces each, which latter alone constitutes the fabric from which the celebrated shawls are made. Ten goats furnish mly enough for a whawl $1 \frac{1}{2}$ yards square; hut this is often found differing both in color and the quality of the wool, wr rather the fine hair, of which the fleere is compusert. The principal points in the most approvent hreesls are large ears, the limbs slender and cleanly formed, the horns not spirally twisterl, and, above all, the fleece being long, straight, fleecy, and white. 
This soft undereoat of the Casbmere is known as "pashum," and is the product from which the famous Casbmere shatrl was made. Mr. William M. Landrum, who was probalbly the first in this country to discover that onr sor-alled (ashmere goat was the Angora instead, through investigations made about 18til, also states that there is a difference between the Cashmere shawl and the Paisley shawl. These are often referred to as being the same shawl. While the filling of both shawl. was of pashum, the chain of the latter was made from the kid fleeree of the Angora. Pashum is combed out in the spring, and is worth, when cleaned, in the country where it is produced, from $\$ 1.50$ to $\$ 2$ per pound. A writer in the Penny Magazine (London) in 1838 says:

The wool is first monher from the animal in the mountains of Tibet, where it is sold for nearly 5 , shillings a pound. It is patked in haskets and sent to Cashmere, where it pays a duty on entry. It is there bleached with rice flour, spun into threarls, and taken to the hazaar, where amother tax is paid upon it. The thread is then dyed, the shawl is woven, and the border sewed on.

So much for the Cashmere goat.

The first (or Davis) importation of Angoras was frequently exhibited at fairs, and always attracted much attention. The reports made by the officials of fair associations were always favorable, sometimes flattering, and as is known, after years of experience, not alway's correct. The United States Agricultural Soriety, which held an exhibition in Philadelphia in 1556, awarded to Col. Richard Peters, who was then the owner of the Daris goats, $\$ 100$ as a special reward. The following report was made upon the animals:

They have beemne known as Cashmere zonts from the pure white color and fineness of their fleerex, and their undoubted Eastern oriwin. The fleeces from the bucks weigh from 6 tu 7 pumbly, those from the ewes from 3 to 4 pounds. The flesh of the (rosses is superion to most mutton, tender and delicious, making them a desirable acquisition to our food-producing animals.

The ease with which they are kept, living as the'y do on weeds, briers, browse, and other coarse herbage, fits them for many purtions of our country where sheep can not be sustained to arlvantage, while their ability and disposition to defend themrelves against fogs evirlence a value peeuliar to this race. They are free from all diseases to which sherel are liable, hardy and prolific, and experience has proven that they rearlily adapi themselves to all prortions of the Cniterl states. The bucks breed readily with the "ommon gats, the secomd aros yideling a Heece of practical utility, whilst the fourth is but little inferior to that of the pure breed.

A flock of valuable woul-bearing goats can le rased in a few years by using gratle bucks.

The following extract is from a report of the special committee appointed hy the American Institute at its exhibition in New York City in 1855:

They have examined with nuch interest the fleece submitted to them, and as weli from their own observations as from the results of a micruscopic examination made 


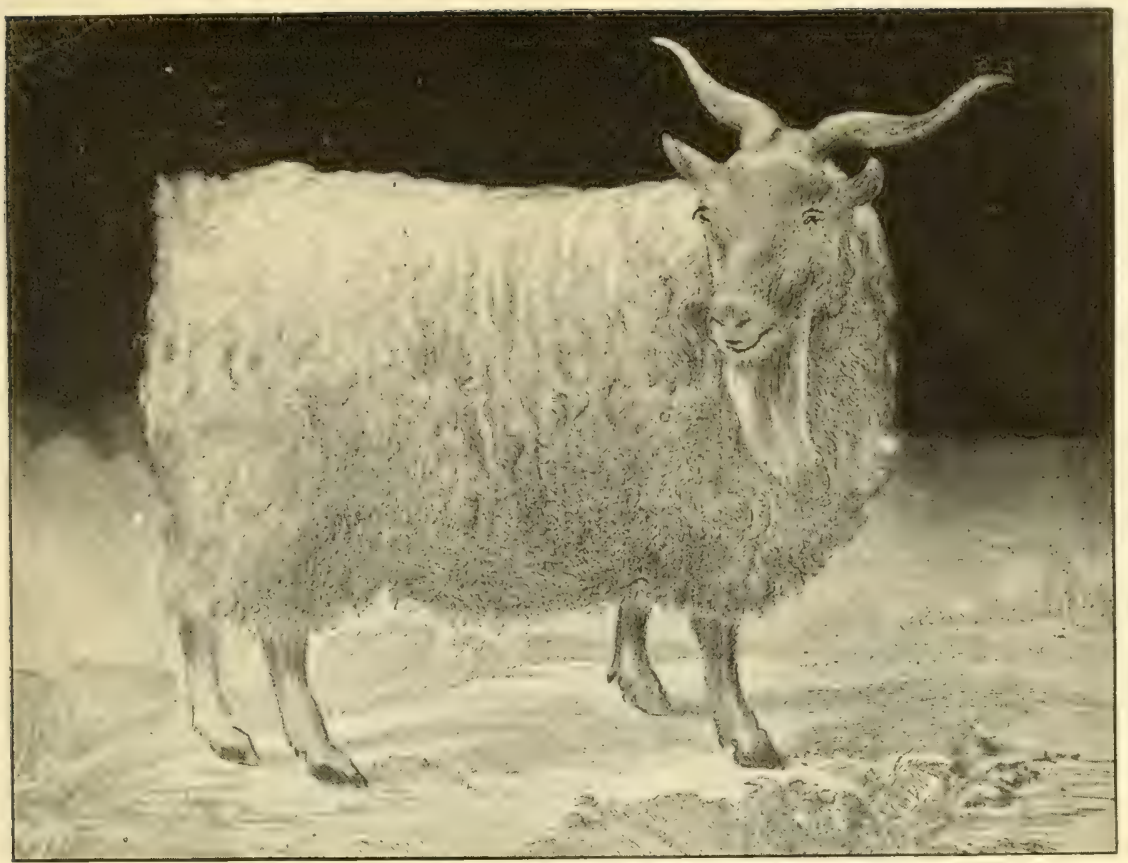

Fig. 1.-ANGORA BUCK. (DAVIS IMPORTATION, 1849.)

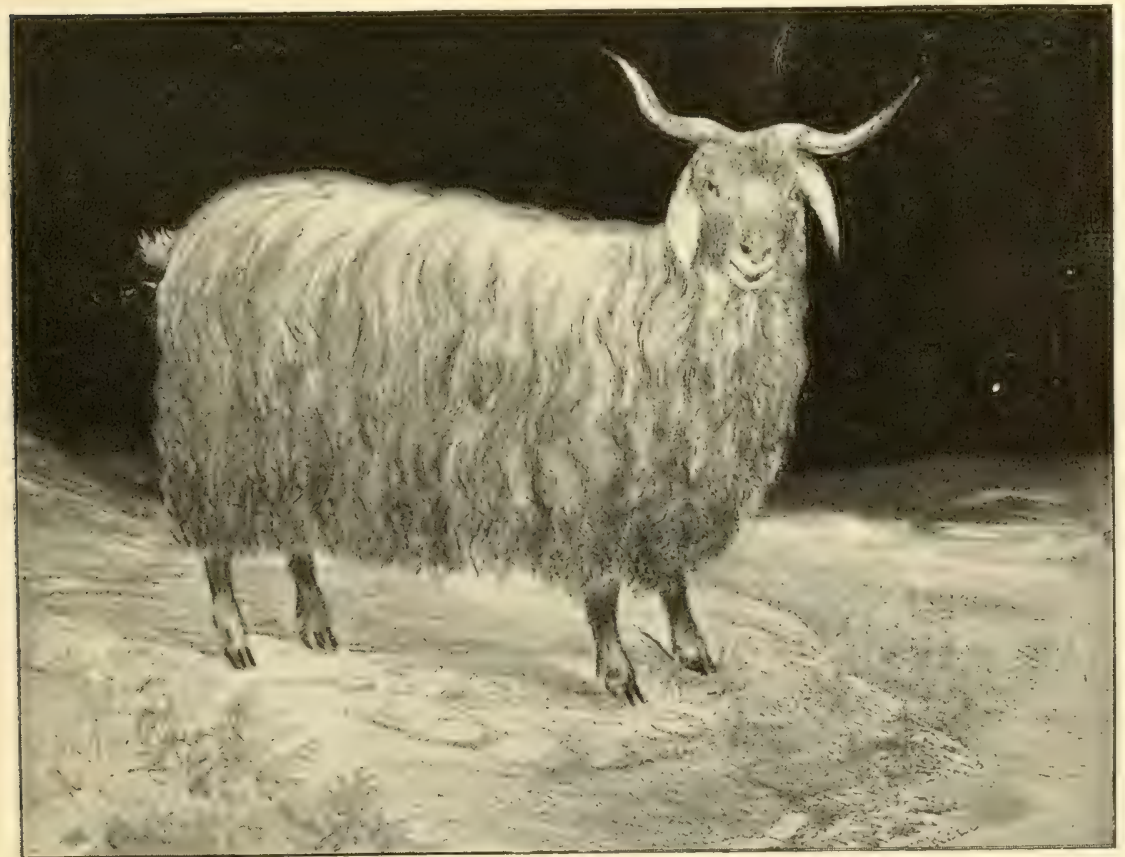

Fig. 2.-Angora Doe. (Davis Importation, 1849. 

and certified to by several gentlemen of scientific eminence well known to them, they are convineed that the fiher of these fleeses is irlentical in character, and fully equal in value, to that from which the highly prized Cashmere shawls were made. The fleeces on exhibition, and now under examination, amount to from $t$ to 8 pounds each.

The enterprise exhibited by the introduction of these animals into this country and their propagation can not be too highly regarded.

First. These animals are long liverl, such heing the (ase with the whole goat race.

Second. They are prolifie, breeding at the are of 1 year, with at periorl of gestation of about five months, and yielding twins alnost universally after the first hirth.

Third. They are hardy, experience having shown that they will thrive well in our climate from feorgia to New Fingland, and that they require coarce and cheap foodas the inferior grasses, briers, bushes, etc.-such as is refused hy other grazing animals.

Fourth. They produce a fleece of from $t$ to $s$ pounds, valued at from $\$ 6$ to $\$ s$ per pound in France, or Paisley, Fcotland, for the manufacture of those high-priced shawls. These fleeces can be produced, when the animals hecome numerous, at a less cost than the common sheep's wool and far superior to it.

Another fact of great practical value to our agricultural interests is the facility with which the Cashmere goats breed with the common goats of our country.

From these and other considerations, of the correctness of which your committee have entire confidence, it will he obvious that every encouragement should he shown this new enterprise - a bold and judicious movement.

B. P. JoHNSON.

Charles J. Goodrich.

JAMES J. MAPES.

A committee for the New York State fair. held in New York ('ity in 1854, reported as follows:

The undersigned can not avoid the conclusion that in the goats imported, and whose descendants have heen the subjects of this examination, we have the firstknown specimens of that valuable race of aninals from whose hairy fleece the celebrated shawls are manufactured known in commeres by the inappropriate name of "red camel's hair." As the fleece does not appear to have deteriorated in the comparatively warm climate of south C'arolina, the distinctive charater of the race is hard to be obliterated, while in the northern region of the Uniterl states this character can not well fail to be permanent. Vieswerl in this light, the introuluction of this animal promises to the of more value to the agriculture of the I'nited states than that of almost any other animal.

JAMES RENWICK.

Josepit R. Chilton.

W. H. Ellet.

Many other similar reports were made hy rommittees of fair asso('iations about that time, hut those quoted serve to show how favorably goats were regarded. It should be stated here, however, that there are in these reports many erroneous statements. For instance. the goat is not the Cashmere; they drop twins oceasionally only, and their Heece never did bring as high as $\$ 6$ to $\$ 8$ a pound.

All of the Daris importation of pureherel Ingoras were purchased in 1853) hy ( $11786-$ No. $27-01-2$ 
of one owned by ('ol. Wade Hampton, of South Carolina: one sold by Dr. Davis to Mr. Davemport, of Vireminia, and one to Mr. (Osborne, of New York. Colonel Peters later imported other's from Asia Minor, which did not prove to be rery satisfartory, as they were gummy. The savammah Republican in April. Lition. waid that colonel Peters was selling his goats at rery high prices, having received $\$ 1.500$ for one buck: that the president of an Illinoin fair was so pleased with one of the bucks on exhiliton there that he offered Colonel Peters "the weight of the huck in silver for it." (colonel Peters is looked upon as the real founder of the Ingora goat industry in the country. Although 1)r. Datris had crosised the Angoras with common goats to some extent, it Was Colonel Peters who demonstrated the possibility of eresting an cxcellent fleece-hearing flock by judicious crossing with common gonts. Other importers were Hon. W. H. Stiles (1860), 8

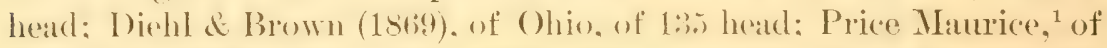

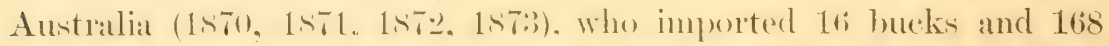
does for his sons. who were settled at Fort ('lark, Tex. John S. Harris (1siti), then of ('alifornia. now of (Dalikey. Idaho: ('. WV. Chenery

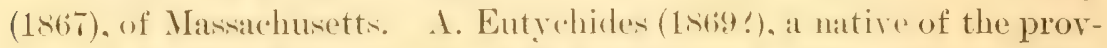
ince of Angora, brought orer a flock numbering 175 and made a vigorous effort to bring them more larerely to the notice of the American public. After several rears of douhtful suceses he returned to the Old World to engage in farming in Thessaly.

John S. I Iarris says that, with the exeption of IHon. I-rael s. Diehl, he is the only man who ever went into the provinee of Angora for the mohar goat: other goats that were imported "ame through agents.

These are about all of the earlier importations from Asia Minor. Of recent years some excellent individual have been brought from Cape Colony. Turkey hats sine 1 sist prohibited the exportation of Angoras, and ('ape (olony, observing' with jealous eye the rapid progress now being made in the United states, has placed an export duty upon Angorat of telon (strti.65). W. Hammond Tooke. Writing of the mohatr industry of cape Colony in the Agricultural Journal of the Cape of froced Hope, says they hare nothing to fear from Turkey or Australlia, but that the Lnited states gives them more concern, as the breeding of Ingoras for mohair is no longer considered an experiment in the United States.

Previous to the outbreak of the civil war there were many farrized flocks in the south and southwent. There were smaller flocks in many of the Northern and Western States. Mr. Diehl, in 1863, mentions flocks containing from 3000 to 1.200 and more in Atlanta, Gat.: Gablatin and Nashville, Tenn.: Rusiellville, Frankfort, Paris, and

\footnotetext{
${ }^{1}$ This statenent is male upon the authority of Gustay . 1. Henerle; lut C. P. Bailey says he has never been able to verify the presence of this importation in Texas, and I am informed that Col. W. L. Black, of Texas, also fails to locate them.-G. F. T.
} 
Georgetown, Ky.; (reenville. Lebanon, Montgomery, and Bueyrus, Ohio; Green ('ounty, Ind.; ('hicalgo, Decatur, and Evanston, Ill.; St. Louis, Maramee, and Fayette, Mo.; Baltimore, Md.; Leavenworth, Kans.; Brownsille. Pittshurg. Washington, and Philadelphia, Pa.; New York City, N.Y.: Boston and Behmont, Mass.; Austin, Tex.; and in the states of Iowa. Michigan, Minnesota, California, and in other localities. So it will be observed that they were so distributed as to test in a most excellent manner the sereral phases of our dimate upon them. On account of the civil war, however, little or no progress was made in the Suth, where the largest herd: were located and where most interest was maniested, until about 1866 . Soon after the close of the war they spreac out into the West, principally into Texas and California, where the natural conditions were most favorable, and where they have, quite unknown to the publie, increased wonderfully in numbers and, in the light of recent events, in importance also.

In the spring of 1861 Colonel Peters sold two 16-months-old bucks to William M. Landrum, of San Joaquin County, Cal. They were sent from Atlantal to St. Lonis hy express ; thence hy steamer to Fort Leavenworth, and thence on foot to California with a wagon train. 'They subisted on the journey by browing on what other animals rejected, and arrived at their destination uninjured and in good condition. Mr. Landrum exhibited them at the State fair the same rear. being awarded a silver goblet and 525 in cash. One of the goats, after siring about thirty kids, died of snake bite; the other one, famous on the Pacifie coast under the name of "Billy Atlanta," lived to be 10 years old, and then was accidentally killed. He had sired about two thousand kids. This buck won the sweepstakes prize over all competitors at erery state fair down to his death; and Colonel Peters stated in 1,66 that his numerous descendant were scattered all along the Pacific "olst, and that "his blood eourses in the reins of over one-half the Angora flocks in that part of the Lnion, estimated to approximate 70,001)." Colonel Peters further stated "that about one-third of the purebreds introduced into California were contributed from the first and original (Davis) importation of $184:$, and that their blood is present in probably two-thirds or three-fourths of the Angora stock on the Pacific coast."

Mr. Landrum was in (alifornia from 1850 to $188 \%$ after which time he went to Texas. He is now at Laguma, Uvalde County, Tex., and, with his sons. is still interested in the Angora goat industry. The Chenery importation was shipped by the British consul in Angora to Constantinople, where they were sorted hy $\mathrm{Mi}_{\mathrm{i}}$. John R. Thompson and the American consul, and shipped by a sailing vessel to Boston.

Ten head of the Chenery importation were taken to California and disposed of as follows: A pair to C. P. Bailey, San Jose, at \$ă 00 each; a pair to Thomas Butterfield es son. Wratsonville: a pair to William

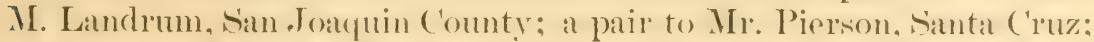
and a pair to Flint de siresent. Monteres county. This lot was the 
beginning of the hreeding of thoroughbred Angroras in California. Prior to this hut two ingora bueks had been taken into the statethe two which were sent by Peters to Landrum.

The Diehl and Brown importation was first taken to Ohio; and afterwards the entive lot, it is helieved, wastaken to California. where the goats were widely disseminated through the state. some of them bringing as much as $\$ 200$ a head.

In 1sis William Hall hought of Buttertield d Fon their entire flock of 150 groats for ahout $\$ 17,000$. The same year .Tohn s. Irarris joined Hall as a partner, and the following your went to' Turkey and purehased ten does and two bucks. These also went to california. It is said that the blood of this importation was felt beneficially in every good flock in the State.

In 1893 C. P. Bailey imported from South Africatwolucks. Pasha (see PI. VII) was one of these, and his gret has heen sent to nearly every State in the Lnion. In 1s!n Mr. Bailey importerd another buck from Cape 'Iown. This animal is the last importation into the Lnited States.

The statement has already been made that the first woats taken to California were purchased of C'olonel Peters hy Mr. Landrum. In 187.2 Mr. Landrum purchased all the goats under sears of age which Colonel Peters then owned and took them to California.

Mr. Julius W Veyand, secretary of the Angora Croat Breederes Asinociation of California, in a report to that organization in 18!1. gives a brief review of the industry in that State. He says that in 1ss.s there were about 100.(10) Angora goats in California, hut letwern that date and 1sis:, owing to the admission into the Lnited Ntates of mohair as (alpet wool, and thus paying but og cents duty per pound, the number decreased to 5.5,our). Mr. ( . P. Bailey is authority for the statement that practically all the goats in California are of the Angora hreed.

Large flockis of Angoras have been sent from California and Texas into Nerada, Oregon, and Washington, where they have been divided into smaller flocks and become the property of many different firmes's. Texas has also sent many over into New Mexico.

Although the foregoing facts show that the Angora goats have heen sow in gaining a standing among the industries of the country, it can hardly he doubted that there are now in motion such energies as will place the industry upon a lational basis. It is believed that the Angorat industry is already emeloging from the ehatos which has enveloped it for fifty yous past, and that it will soom be as firmly established as any other stock interest in the Lnited states. A recent issue of Irool Markets and Sheep says:

After careful review of the situation, past and present, the Angora goat industry of this country we clearly conceive is destined to be one of very great importance in our agricultural economy. (Our broal acres and diversified geological and chimatic conditions give ample scope and abundant suitable conditions for the carrying on of the business to a large extent and profitable issue. 
IESCRIITION OI' 'IHE ANGORA GOAT'.

Mr. Israel S. I)iehl, hearing a commission from the Commiscionen of Agriculture. visited the province of Angora in 1 stit to investigate the mohair industry. Here, where there were once in operation 1,70x to 1.800 looms working up the mohair feeces. lo fomd but a few hun dred remaining, struggling hopelessly against the fatal competition of European machinery and the aggressive policy of the European Gorermments. The fleeces were exported to Europe for fabrieation, thus rendering Turkey tributary to the monopoly then rxisting in: this industry in Furope. The European demand for the raw material was so great and the facilities to fabricate it so much better and cheaper that 'Turkey was compelled to export the raw mohair. In order to meet the demands for manufactured mohair the Turkish growers. without wise foresight, began the practice of crossing the Angora upon the common Kurd goat of that country. 'The inevitable result of such a policy was to hring about to a litre extent the conditions which have olotained in the United States, mamely, a breed of Angoras of uncertain purity. 'This fact, coupled with the belief that proper "are was not exercised in selecting the animals exported to this country and that they have been carelessly bred here, has led some excellent judges of Angoras to express the belief that there are really no purebred Angoras in the United States.

These conditions have produced various types of Angoras, even in Asia Minor, and a minute description of one would not apply to all. Some strains have fox-like ears, while other's and generally preferred ones have long pendent ears. In this country care must always be exercised to cull the offeolored kids out of the tlock. These may he the result of atavisu, where a cross was made upon a common goat either red or black; hut it is reported hy some that different colors are found in the proviner of Angor:a among what were supposed to be purebred animals. Mr. Gustar A. Hoerle, one time corresponding secretary of the American Mohair Growers" Association, and an authority of note on Angora goats, mentions having yellow and red goats in his own herd, and said that "some of the kids became quite a variety show."

Mr. S. C. Cronwright Schreiner, of Cape Colony, in his excellent work on "The Angora Goat," has compiled the descriptions of almost all writers on Angora goats. He quotes Mr. Henry O. Binns, who spent twenty years in the mohair districts of Aria Minor hetween 1864 and 1s86, and who studied them during that time, ats follows:

The pure Angora in his prine is about the size of a five-months-old Cape [Cape of Goud Hope] kid, with small thin horns, wooled all over the hody, their hair almost covering the eves; exceedingly delicate, and so subject to disease that no one cared to keep him. What is to-day (alled the purebred Angora is like the English thoroughbred horse-the result of crossing and recrossing until body, class, points, ete, have attained to what is generally considered that the throroughbred Angora ought to be. 
Mr. Schreiner opinion of what a purebred Angora is, wiven on page 58 of his book, is as follows:

I think it is certain that the original purebred white mohair woat was a small, very

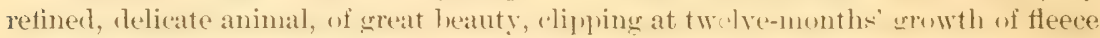
about from 2 to 4 pounds (according to age and sex-kids considerably less) of dazzling white, tine, soft, silky, very lustrous mohair, wrling in ringlets from 10 to 18 inches long, with merely the minimum of oil in its flex's rexuivite to the growth of hair of the highest excellence, so small in amount as to be inappreciable to the unkkilled observer. It was perfectly chothed in every part; it hard short, silky, courly hair about the face and down the lower parts of the leges to the hexis; a soft, silky, curly "kuif" (tuft on the forehead), and small, thin, light-colored horns. The ewe was of course smaller and finer than the ram, and had only one kid at a birth (of this there is abundant evidence).

Although Mr. Schreiner thinks the Davis importation to this comntry was among the best hred goats that ever left Turkey, it will be noticed from the pietures of two of them shown herein (see IPl. I, 1). 16). which were said by (olonel Peters to be excellent. that the mohaie does not extend " down the lower parts of the leges to the hoofs." It is dombtful if any sueh Angoras maty be found existing at this time. however probable they might have heen in their original purity.

The following is quoted from 1)r. John Bachman. of Charleston. S. C .. who was appointed hy the Southern Central Agricultural Association of Georgia to report on the Angoras belonging to Colonel Peters, of Atlanta:

The Angora goat, more especially the varieties it has proflued, is deseriber by

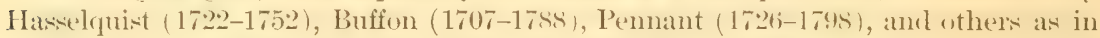
general of a beantiful milk-white color, with short legw, and hlack, spreading, spirally twisted horns. The hair on the whole louly is disposed in lomeg pendent spiral ringlets; itw ears are pemelulous, and the horns of the female, insteal of clivaricating as in the male, turn backward, and are much shorter in proportion.

Mr. Diehl" (1s6:i), adopting to some extent the same language as Dr. Bachman used, describes the Angora as follows:

The Angora goat, and more especially the varieties it ha I moluced, are probably the most valuable of all the goat family, and have heen ably dexcribed hy Naturalists Buffon, Pennant, Hasselyuist, and travelers as good-rizerl animals, genemally of a beautiful milk-white color, with short legw and wide-sprealing, spirally-twisted horns. The wool is described as a very beautiful curled or wavy hair of silvery whiteness, with a fine downy wool at its base, and this hair is disposed in long, pendent, spiral ringlets on the whole buty. The horns of the female, insteat of spreading, as in the male, turn backward, and are much shorter in proportion. Those of the male are long, spirally twisted, but the size and direction are very different from the conmion gont, being anenerally extended from 15 to:30 inches in height on cath side of the head, while those of the female are near the ears. The hair, or wool, often sweeps to the ground, and is usually from 5 to 12 inches long, especially in the older bucks, but then not so fine.

This hrief description, he said, applied to all the Angoras which he saw in western Axia, Furope. and in this country. which amomed to

1 "Report on Asiatic Goats," United States Agricultural Report, 1857, 1. 58.

2 "The Cioat," United States Agricultural Report. 1863, p. 222. 


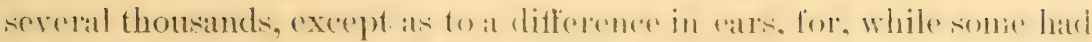
pendent ears, others which he examined had rals axceedingly mali and short.

Mr. Diehl also mentions a rariety of this goat in Angora which wats hornless. There is reason to believe that an intelligent system of hreeding would produce such result. Such an end hats heen attained with cattle and is entirely feasible with goats.

In this connection, interest will be manifested in at note from ('ol. William L. Black, of Fort MeKavett. 'Tex., who says he has an interest in a flock of hornless Angoras in Iowa. He ways that there is no doubt that it is a "distinct breed." His experiment the first reason was seren hornless kids from eight does with horns, and the secend season (1900) he raised "fully 90 per "ent of hornless kids." IIornless Angoras, however, were not rery rare in Asia Minor, and it may be that there were some in the vilayet of Angora. They were alled Kastamoonere ${ }^{-}$Angoras, taking the name from the vilayet of that name. The vilayed joins that of Angora on the north and forms a part of the northern boundary of Asia Minor. Sereral yeatrs ago Mr. William M. Landrum imported one of these Angorats. IIr wats known as "Hornless Johmnie." Mr. Landrum was not very proud of this animal, as would appear hy this from his pen in 1.san:

He sheared 10 pounds at six months, but his hair was too coarse for anything but wigs. I bred him to a lot of purebred Angora ewes and got the best lot of bucks for low-grade ewes that I ever saw; got $\$ 50$ premium for them over purebred Angoras. I paid $\$ 2,000$ for him, and lost him the second year. If he had lived I would have injured my purebred flock with him. As it was, I killed for mutton several ewes got by him from purebred ewes to get them out of the flock. I could not certify them to be pure Angoras.

It is to be hoped that Colonel Blatek's efforts to originate a hornles, variety will produce better results than were obtained from Ilornless Johmnie. Of course, the presence or absence of horms need not necessarily have any influence upon the qualities of a goat.

Probably the best description of the American Angora is that given by Mr. Gustar A. Hoerle, which is given below. Reference is to first-class animals, and not to grades of various degrees:

The body should be long, and the rounder the better; the back straight, with shoulders and hips equally high from the ground; shoulders and quarters heary amel fleshy; chest broad, indieating good (o)nstitution; the lexs shondet bes short and st rong: the head is in shatye like that of a common goat, but lexs coarse and cleaner cut; thes horns are heavy, with an inward twist, inclining backward and to the outside.

Except just the face and legs, from the hocks and knees down, the entire animal should be densely covered with mohair, and neither the belly nor the throat nor even the lower part of the jaws should be bare, but should have a good envering of fine, silky mohair, and with the finest speenimens the mohair tuit on the foreheat should bet well developerl. The mohair shonld hang in long, curly ringlets. However, not every Angora goat which shows these perfectly curly ringlets of the mohair

${ }^{1}$ Thim name is variously spelled-Kastamoonee (preferred hy Lippineott , Kastamouni, Kastamuni, Castambool, Castambul, Costambone. 
must necessarily be considered a thoroughbred; whilst, on the other hand, there are quite a number of really handsome and valuable thoroughbreds whose hair has not that much-desired shape, owing entirely to climatie and nutrimental influences, as well as to advancing age. Thoroughbreds and all nonshedding grades can easily be recognized by the peculiar shape of "points" of their mohair, each end showing plainly that it has been "cut off," instead of running gradually to what is called a "steeple point," which is found with the hair of all kids and of shedding grade Angoras. The plainer and longer this blunt point shows towarl the end of the reai the better is the fiber of the mohair, and the more valuable is the hair for combing purposes and the smaller the perentage of molage and waste. After sherhling, as well as nonshedders after shearing, the mohair grows very rapidly for some months. It grows slower toward the end of the year, and, with very bad climatic and nutrimental influenest, almost stops growing entirely. Therefore, if the late fall shearing is practiced, Angoras need good care during winter. The more even in length and quality the mohair is on all parts of an Angora body the better. When

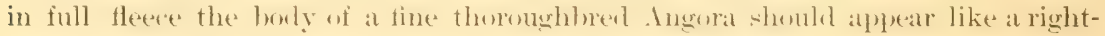

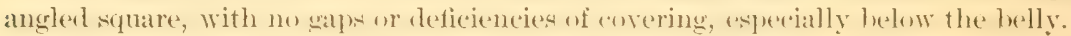

Mr. Hoerle is encountering some opposition to his ideas of the nonshedding virieties. Because of this difference of opinion the Bureau submitted the question. "Do thoroughlureds (fourth ("ross or above) shed if not sheared!" to a large number of the hreeders of the country. A summary of the replies received is given elsewhere (see p. 79).

A characteristic of the common goat that is very objectionable is the ever-present offensive odor from the bueks; in the Angora breed this odor is entirely absent, except at the rutting season, and then it is noted in a slight degree only. The oflor in a fleece of mohair is milder than that in a wool fleese, and is not at all offensive.

NAMES OF THE BREED, THE SEXES, AND THE MEAT.

NAME OF THE BREED.

There was no difficulty in dropping the name "Cashmere" as soon as it was known that the Angora goats did not belong to that breed, but there are a few uninformed persons who still refer to them as Cashmeres. Owing to the prejudice existing against " the goat," it has been suggested and strongly urged hy some that the easiest and quickest manner of ingratiating the Angora goat with the people is to drop the word "goat" altogether and call them simply "Angoras." In other words, it is proposed to pretend that this animal does not belong to the goat family. It would still be a goat notwithstanding, and students of science would forever he pointing out the pretense. Besides, the use of the nume "Angora" alone would almost eertainly lead to the commission of errors. Everything of American origin is referred to as being "American," and the various animals from the vilayet of Angoral could with equal propriety be ealled "Angoras." For instance, the long-haired cat from that province is quite well known in this country and is called an "Angora." 
The Amerinan people desire to know things hy their right manes.

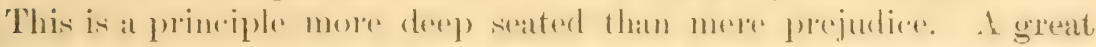
amount of prejudier had to be overeme he fore the tomate wats genereally used for food, and we can imagine in a degeres what wats said of the first man who ate an oyster or a mushroom. But these "poisonous" and "nasty" things are now recognized everywhere not only ats delicacies hut as most nourishing food. So will it he with the flesh of Angor: goats when it is generally known that it is palatable and nutritious. A perusal of the many reports received hy the Burean of Animal Industry shows that there is no objection to Angora goat meat in those localities where these goats are raised.

The Angora has everything to recommend it -nothing to rondemm it; and there seems to he no real good reason why its identity should be lost hy dropping the name "goat." Whoerer seres the animal can not fail to admire it, and whoever sats of it is quite certain to like it if he is at all fond of mutton; and the prejudice against it will disalppeav as the industry expands and derelops throughout the rountry. Indeed, a knowledge of the Angora goat shows that the existing prejudices will not hold against it: that those projudices are lased upon the reputation of the common goat.

NAMES OH THE SEXES.

There are no weil-established names for designating the sexes of goats. The male is indiscriminately called "male." "sire," "huck." "ram," and "billy," and the female, "doe," "ewe," and "namy." Oftentimes a writer uses two or more of them in one article, showing that he has not adopted any of them. One of the questions submitted to the men was this: "As to designation of sex-do you call the male "buck," "billy," or "ram," and the female "ewe," "nanny," or" "doe!" More than half of those who replied called the male "buck," and nearly half called the female "doe." The objection of one writer" that the plural of the female, "does," conflicts in reading with the verb "does," will not hold, as a sentence will not "make semse" with the one word used for the other. In this bulletin it has been decided to refer to the sexes as "buck" and "doe."

The castrated animal is called "wether," as with sheep. In Capre Colony he is ealled a "kapater," and the sheep wether is there called a "hamel;" but there is no reason why we should adopt these terms.

The young is called the "kid." There seems to be ahsolute unanimity in this matter.

NAME OF THE FLESH.

Our correspondents are apart in the use of the terms" "Angora mutton" and "Angora venison" for the flesh of the Angora goat, hut the greater number of them call it by the former name. 'Those who pastured their goats upon some grasis or clover as well ats upon browse, 
and then finished their fattening with grain, produced a meat so nearly like the best lamb that it required experts to detect a difference; these people use the term "Angora mutton." In other instances, where the animal is fattened by browse alone, there is imparted to the meat a game flavor, which may be intensified or reduced by the character of the brows: people who use the meat under these conditions eall it "Angora venison."

Some correspondents, with erident thoughtlessness, refer to the meat as "goat meat." This is a serious blunder if a successful effort is to be made to popularize the use of Angora mutton, as there is a wonderful difference hetween the flesh of the common goat and that of the Angora. For this reason the prefix "Angora" should never be omitted.

THF USES OF ANGORA GOATS.

A large class of people in some way have become possessed of the opinion that the goat is practically a useless animal. They do not reach conclusions upon investigations, however, and do not discriminate hetween the different breeds. To them a goat is a "goat," and there the argument ends. Investigations prove that the Angora goats are not only classed among the most useful of the domestic animals. and have been so classed for thousands of years, but their usefulness is manifested in a variety of ways. The fleece, called "mohair," furnishes some of the finest of fabries among ladies' goods and is used in various: other manufactures; their habit of browsing enables the farmer in a wooded locality to use them to help in subjugating the forest; their flesh is exceedingly delicate and nutritious: the milk. though not so abundant ats with the milch breed of goats, is richer than cow's milk; their tamned skins, though inferior in quality to the skins of the common goat, are uned for leather; their pelts make the neatent of rugs and robes; they are excellent pets for children; a few of them in a flock of sheep are a protection from wolves and dogs; their manure is noticeably helpful to the grass which follows them after they have cleaned away the underbrush. These are all vital subjects of varying degrees of importance, and will be considered here under appropriate heads.

BROWSING AND PASTURAGE.

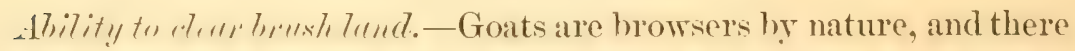
is no regetation they will eat in preference to leaves and twigs of bushes. While thin fact rould at once establish them as an intolerable nuisance in an orchard or garden or any other place where desirable shrubbery is growing, it also shows that they may be of great value in many localities where it is desirable that underbrush be destroyed. They are ommivorous eaters and seem particular to aroid that character of regetation which other kinds of live stock prefer. Every leat 


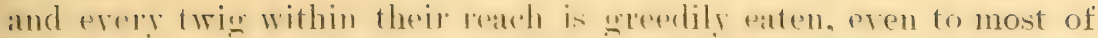
the hushex and weeds that atre considered poisonous to other ruminants, while a rematiably few weeds ane passed by. They will desert the finest clover and blue grass for such an outlay.

The inherent tendeney to elimb leads them to hillsides and rocky cliffis, and they prefer such situations to any of a level chatracter. Here nature meets their necessities hy dwarting the bushes so they may be browsed asily; the soil is quickly drained in the erent of rain-for ther do not like wet land: and the stones serve to keep the feet trimmed properly by the wearing process. This is the situation that the goats would choose; lout the farmer might choose to turn them into a dense mass of brush and weeds anywhere and they will at once begin to convert it into the most beautiful pasture.

In those loealities where valuable land is completely subdued by brush the goats are considered of more value for the purpose of chearing it than for them mohair or meat. 'They thus become one of the farmer's important tools. Their value in this respect must he measured hy the value of the land which they will render cultivable. It is said that in Oregon, where (hinamen had been paid as high as \$20 an acre for clearing off hrush, goats had done the work eren hetter. sprouts will spring up hehind men's work, but goats will keep them down until they cease to appear. 'True, the goats require more time than men, but their work is hetter. In this comnection an article which appeared in the Country Gentleman of .Jamuary 11, 1 !)(1), is of special interest:

In 1870 MIr. Landrum exhibited ten head at the tregon State fair. They were put in a brush pen, where they ate out the brush and peeled the naplings during the fair. As the Willamette Valley was covered with brush and farmers were paying Chinamen \$20 and Anericans \$22 per acce for grubhing, Mr. Landrum suggested the employment of goats instearl; and, to demomstrate their effectiveness as substitutes for grubbing, he lett them on :3 areres of slashect hrush. At the end of the first year the roots were deat and discolored, and at the end of the second year they were rotten and the land mellow for the plow. Then he drove up his California herd of 2,400 , the result of fifteen years of breeding, and sold them in small lots from Jacksonville to Portland, scattering them throughout the Willamette Talley. He says he sold as many more later to go to Oregon, where there are now 80,000 hearl, mostly in lots of 25 to $300 . * *$ * He believes that they are more profitable than any other farm animals. They have cleared humberls of thousands of atres of hrush land in Oregon now in cultivation.

Through the courtesy of Dr. J. R. Standley of Platterille, Iowa then illustrations are presented which, as he naively states, shows woodland "before goating, during goating, and after goating." Work cam not possibly emphasize the work of goats as brush destroyers so strongly as these illustrations. The first (Pl. II) shows simply a dense masis of hazel, plum, erah apple, several varieties of oaks, and weeds as high as the fence. This land was as nearly like that shown in the other 


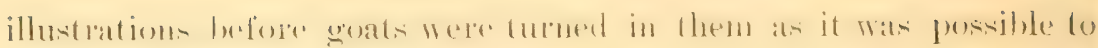
find. The second (

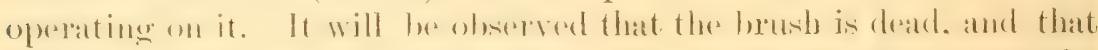
the wreds omly appear to he alive. The third (Pl. IV) shows the "finished product" after two yeatrs. The gonts had been in the tract shown in Plate III hut twelve months when this photngraph was taken. "The shrublery that was too larege for the geate to " ride down" was (nt down, the geats eompleting the work by atting the soft twige and leaver. The last piece is ready for cultivation of for pasture for (attle, sherep), of horses. When the goats were first turned into this frate it was as full of hrush as the tract shown in Plate II, and they were allowed to run upon it but two years.

The heneficial efforet of the goats is not all in the clearing of the land

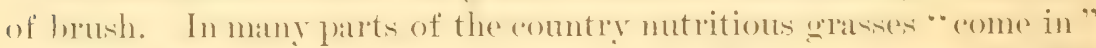
after the geats hate done their work. In the tract shown (Pl. IV) blue grass has hy matural methods formed a most exorellent pasture.

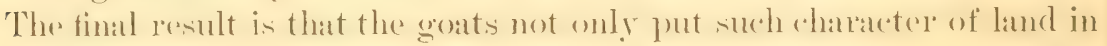
condition for enltivation, but atually go further hy ronverting a wildernesin inte a good pasture, thus proparing the way hy cheapest methods for sheep, cattle, or horses.

D)r. Situndley says that in that patre of Iowa where he lives " 100 Alleoras to eateh to aleres of this land for two years would make it as rlean as a lawn and as perfecetly set in hlue grass ats a lawn." He has bou ateres of such land clealed in this manner. This land now supports ome strer to each acre, whereas before it was cleared there was not enough grasion an acre to make a sheep) or goat a single ferel. The same experiencer is reported hy Mr. (2. M. Beck, of Beargrowe. Towa. who sals: * After rumning them on such lands here a few years we have a fine blue-grass pasture."

1)x. Standley 's 'xperience in the ('mp)loyment of goats for clearing land is extensive, and thousands of groats have leen taken into Iowa mpon his recommendation. It will interest the reader's of this paper to see the following from his pen:

Land can be cleared of the worst brush known to this country for a little less than nothing by Angora goats. Some one asks how. Simply this: Angora goats will pay a profit and live on leaves and weeds, leaving the land cleaner and nicer than can be done in any other way. Many persons have the idea that goats bark the trees and in that way kill them. They also think that goats wholly eat the hazel and other small brush. There is nothing in this. Goats are no worse to bark trees of any

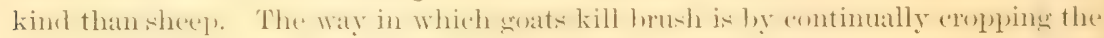
leaves, which serve as the lungs of the brush. The continued cropping of the

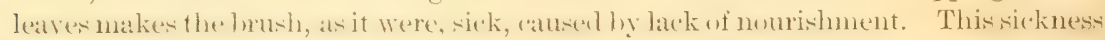
sinks to the very extremity of the roots, thus preventing sprouting. Any and all kinds of husher ate in this way wasly killed. Some kinds of brush and some kinds

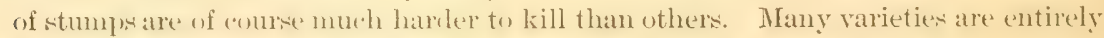
killed by one summer's trimming of the leaves. Almost any are killed ly two years' 
trimming. To clear the worst bush de not cut anything that the goats can reach or benrt. The tallest or largest is better note ent. All trees and saplings should be cut,

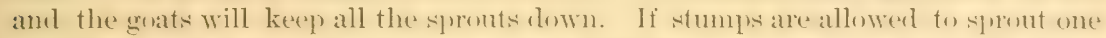

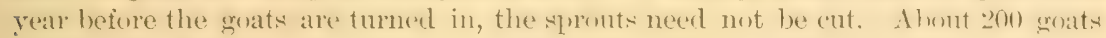
for 40 acres of brush will in two or three years make the land as clean as a garden. If the pasture has only patches of brush, tum in a few goats and it will make more grass for other stock than if the goats were not in. They eat very little grass when

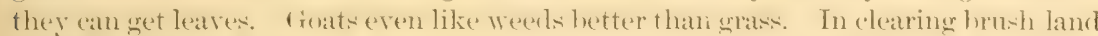
in the old way by grub and plow there are always left many eyesores in the way of brushy nooks and bends and steep places which ean not be plowed.

There are millions of ateres of land in netarly every State in the C'nion which might be much more than doubled in value by the use of Angora goats at no cost at all. ('ommence and count the worth of your lami, then the fencing, and see if you can afford to leave your brush land so nearly worthless for all time. Then count the cont of grubling and plowing, if indees such land is susceptible to the plow. No man can affort to grul, and plow hrush lamel in this day and age of the world any more than he (an afford to llant a large field of corn without a planter. Tn hilly or mountainous portions of the country the Angora goat can be made to do a great service in the way of "learing the unlerhrush, when the land will bring grass after the brush is gone. It would surely be a paying business to buy up large tracts of

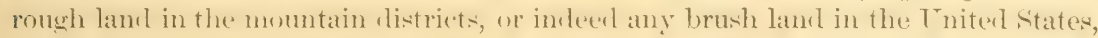
and clear the brush and set in grass. Afterwards, if the owner liked other stock better, he night dispense with the Ingoras. In many places where the comotry is too hare to furnish sheep with sufficient feed govats will do exceedingly well. In many places where lewes arts abmolant and there is scarcely any grass, making it impossible to profitably keep sheep, goats will do admirably well.

While Dr. Standley's experience is that goats will not to any appreciable extent peel the hark off shrubbery, the experience of others is quite the reverse. Mr. I. T. Fuchs, of Tiger Mills, Tex., writes in the Filrm and Ranch of Ootolyer 6 , 190(), that one summer he purchased some Angora goats which amme from a lange? where they had killed out all the tall sumar trees. On his own range was much of this brush, and his goats had nerer touched it. It was a troat for the newly purchatiod goats, and they " preelod the hatk nicely and clasued off' every sumac tree in the pasture an high as they could reach (ahout if feet), and in a few days you condel see the white. smonth-peeled trees with their dead tops for miles all orer the pasture." He adds that fifty men with hatehets could not have done the work so tast or with so much pleasure. Further, he says the goats that had all along heen in the pasture "took the hint and went at the bark peeling also." All of which goes to show that the goat is an intelligent amimal and is capable of learning much by observation.

Mr. (२. M. Beck, of Bear Grove. Towa. writes that he had goats on a 2.3 -ace tratet, fenced, in one cormer of which were 5 acres of clorer suitable for hay. 'Tler goats not only cleared the way for the rover', but ate the hrowe instead of the clover. The goats were turned into

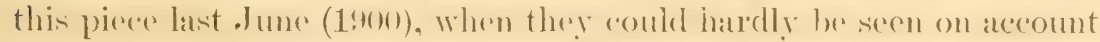
of the hrush, while now (september) they (an les sern anywere in it. 
Of no less interest is the following extrat from an article by Col. William L. Black, of Fort McKarett, Tex., who writes from an experience of many years:

The brush question is a most serious one in a great many of our States. So long as land can le kept under cultivation the brush "an le kejt down; but when it is once thrown ofeen to pasture briers and hrush of all cleseriptions begin to grow and soon cover the entire surface. Even in our own State of Texas many millions of acres are growing up into brush thickets and will soner or later hecome worthless for pasturing cattle, and in many of the Western Territories the same conditions exist. It is suppered that this has been produced by an increase in the rainfall, but I am inelined to think it is not altogether due to this fact. That brush and trees are indigenous to many of our so-called arid distriets an be rery eatily proven by the great guantities of rosts that the present inhahitants dig out of the gromel for fuel purjoses. Not a tree can be seen for hundreds of miles, get these great roots can be found alnost everywhere on the prairies and are a substantial witness to the fact that there was an alumlanes of trees there at sme time or other. Bexore this portion of the United States was occupied by the white nan it was a common practice of the Indians to hum the high prairie srass every fall or winter in order to hunt wild game that was so alumelant in this part of the romery. Buffalo am deer were as common then as cattle and sheep are now, but the grass was so high in places they conld wot be seeen, and the Indian would hurn it off to be able to hunt them more readily. This undoubtedly destroverd much of the genwth of trees and, in my opinion, is the true explanation of the roots that are now fomel in many parts of west Texas, New Mexico, and other Western Territories.

The question is a very important one; and if the goat can be used to keep this growth back, it is certainly well worth the attention of many of our landowners, who may, in a few years, find their land practically worthless. A personal friend writes me that "many pastures are growing up to oak brush and hazel brush in the North, and in Tew England they are bothered with ferns (ealled brakes), berry bushes-blackberries, raspherries, eto." This kind of fare would he "peaches and cream" to a goat, and in a year or two the owner would be relieved of a great nuisance, the groats would grow fat, and the land would be restored to a proper condition for grazing wther stock on it. Another correspondent in Maswachusetts speaks of a certain small island he owned which was so densely covered with brush as to be utterly valueless except to grow mosquitoes. I hear of many parts of the East that are seriously troubled with brush, where many thousands of acres are of no use for srazing purposes, and the protit in farming will not justify the ost of grubling it. In the Southern States many farms have become worn out and are growing up into brush and weeds. The Angora goat is the proper animal to employ to put these lands in a condition either for cultivation or grazing cattle. But a number of my correspondents have asked me what they conld do with the goats after they hat reared the land. In reply to this I will say they can well afford to saungher them and feed them to hogs, but this is not necessary now. The fashion has changed since I slaughtered goats for their hide and tallow, and there is no trouble in selling all the goats you send to any of our large meat-packing markets.

Mr. E. H. Jobson, haring in mind the narkets as well as the clearing of land, writes as follows:

The hest and most effertive way to clear lorush lamil with Angora goat is as follows: It will not be necessary to put up a very high fence; 4 feet of close fencing is plenty and will be sufficient to keep the goats in. The proportion of goats is two and onehalf to three goats to an acre of ordinary thick brush land. I believe the cheapest way to clear your land is with yearling wethers, as will be seen later on. If wethers 


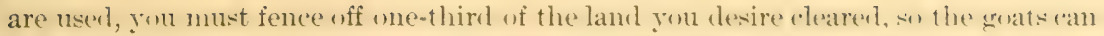
not get to it. The proper time of the year to turn them lome on the hrush is after the spring rains have ceased, whish is usually about the 1 st of Junt. By this time the leaves will be well matured, and the goats immediately proceed to strip the brush of its foliage, which leaves the stems and hranches exposed to the hut sum, which couks them and kills the brush from its deepest roots to its topmost brander. The hot sun being the most effective, and there being no rains to revive the sap, it makes quick destruction of the hrush. By the time that the groats will have the laresest porfion of the land cleared it will he well along in Alugust, and it will now be time to turn them in on the piece of land fenced off at the start, which is fresh and alsundant. In connection with the hrush feed allow them one ear of corn a ray, ame at the end of six weeks they will have cleared the remainder of your brush land, and the corn you have been feeding them will have them in prime condition to fos thrown on the market, where they will hring as much as, if not more than, you pail for them. The result is that you have cleared your land, at most, at an actual cost of 50 cents an acre, and besides that, your land is now ready to set in blue grass, which will enable you to rent it to sheep growers at $\$ 2.50$ per acre', thereby causing the idle: land to

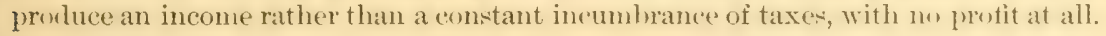

An illustration of the value of Angora goats in clearing land is given by $\mathrm{Mr}$. Abe Blackburn, of North Yamhill, Oreg., who ways that he now has a pasture that will keep 200 sheep which did not have grass mough to keep a goose when he turned his goats into it a few years ago. The goats have killed out the brush, and the grass hats taken its piace.

The following quotations from others who have had experience with goats as brush destroyers show how well the work is done, and, to some extent, the character and kinds of brush eaten:

When confined in small hushy fastures they have been profitable in clearing the land. Some of the finest vineyard lands in California have been clearerl ly goats. A farmer in western Oregon, who has for several years rum a small flock of goats in a pasture with dairy cows, says the lasture now produces double the grans it disl before he purchased the goats. Lands formerly producing nothing but brush and ferns are now covered with clover and bunch grass. A farmer in Iowa writes as follows: "Their value as hrush-land cleaners can hardly be estimaterl. To a jerson who has never seen the results of the application of Angoras to hrush lamels, a ride through my blue-grass pastures is a revelation. Where three years ago the gromm was densely covered with an undergrowth of hazel, (ral) tree, wak, blackberry, ancl other brush, it is now growing the finest hlue grass. It present I have over 600 acres which have been reclaimed, and a comservative estinate would be that the value of the land har thereby been enhancerl at least $\$ 10$ an are." $-1:$ I'. Brilen, San Jose, Cal.

Angora goats like a variety of food; they live principally on leaves and young and tender barks and twigs of bushes and small trees, but, if necessity compels them, they will also eat weeds and grasses, and for a tine do well on them. The quality of a goat pasture, therefore, depends upon the amount and rariety of hrush, enpecially evergreens-as cedar, hemlock, live oak, holly, etc.-which it contains, for on these, as well as the tender bark and twigs of all kinds of bushes, they live principally in winter; and the more of it they find the less grain and hay do they require during the cold spells.-G. A. Iloerle, Ridgewood, N.J.

For clearing out thickets and undergrow th of all kinds there is nothing hetter than these goats. Their pasture will sure lowk as clear as a cleanml-up pienic grouml ats 
high as they can reath when stanting on their hind legs. In this way they can reach 5 or 6 feet high, and they hend down everything they can reach with their fore legs. The brushier the ramge the hetter, and the more different kinds of brush and weeds on their range the better they will thrive.-H. T. Fuchs, Tiger Mills, Tex.

They more than pay for the expense of keeping them by clearing my land. They clear off the willows, haws, buck brush, and squawberries and leave a good bluegrass pasture where there was a nuisance in the first place.-J. D. Lewis, Colo.

He will eat buck brush, black oak, hickory, and all other kinds of brush, jimson weed, ironweed, smartweed, and every other weed that grows, leaving the grass for other animals that will feed after the goats.-R. C. Johnston, Lawrence, Kans.

There is coned grass here (Wyoming), but my goats won't eat buffalo grass. They will hrowe on sagel,rush, greate worl, serulb cerlar, scrul pine, laurel, and willows; but they refuse to eat the best grass that grows. - W. W. Eheler.

In Arizona the principal and favorite bow wing is live-oak brush.-.J. F. Holder, driz.

The statement is made in a previous paragraph that goats are omnivorous caters, apparently preferring those kinds of vegetation that other animals do not rat. The information in the quotations just given indicates that they will feed upon a great variety of plants. With the object in view of ascertaining the different kinds of plants that these goats foed upon, the Bureau requested several stock raisers in various States and 'Territories in the country to report answers to the question, "Trhat kind of hrowse do youl goats have?" Some information of this character is in the quotations ahove and more will be found in the replies copind below. credit for the statements being given to the State only:

Ali kinds of bushes, such as scruboak, cedar, etc., in Texas. In this part of New Jersey most everything that exists in Texas, execent soruh oak and live oak, may be found.-New Jersey.

Black oak, sumac, buck bushes, briers, and all kinds of weeds. They will not eat grass if they can get browse.-Missouri.

liuk hush, chlers, sumat, prickly ash, briers, srapevines, jack oak, ash, sycamore, hasswood, and hickory. The latter they do not seem to care much for.-Kansas.

Brush, weeds, and grass.-Texas.

In southern New Mexico they have live oak and mahagony. They do best on scrub oak.-New Mexico.

Oak, hazel, vine maple, ash, willow, rosebush, thimbleberry, blackberry, buck bush, service berry, crab apple, haw berry, soft maple, and some fir.-Oregon.

Mostly mountain oak and other classes of underbrush. They will not eat grass if brush is obtainable.-New Mexico.

Oak and hazel.-Oregon.

Maple, hazel, willow, fir, thimbleberry, cascara, vine maple, cherry, alcler, and salol.-Oregon.

Willow, ash, and buck bush on low, swampy land in summer time, and straw and fir brush in winter months.-Oregon.

Apple, fir, oak, ash, willow, maple, and poplar.-Uregon. 


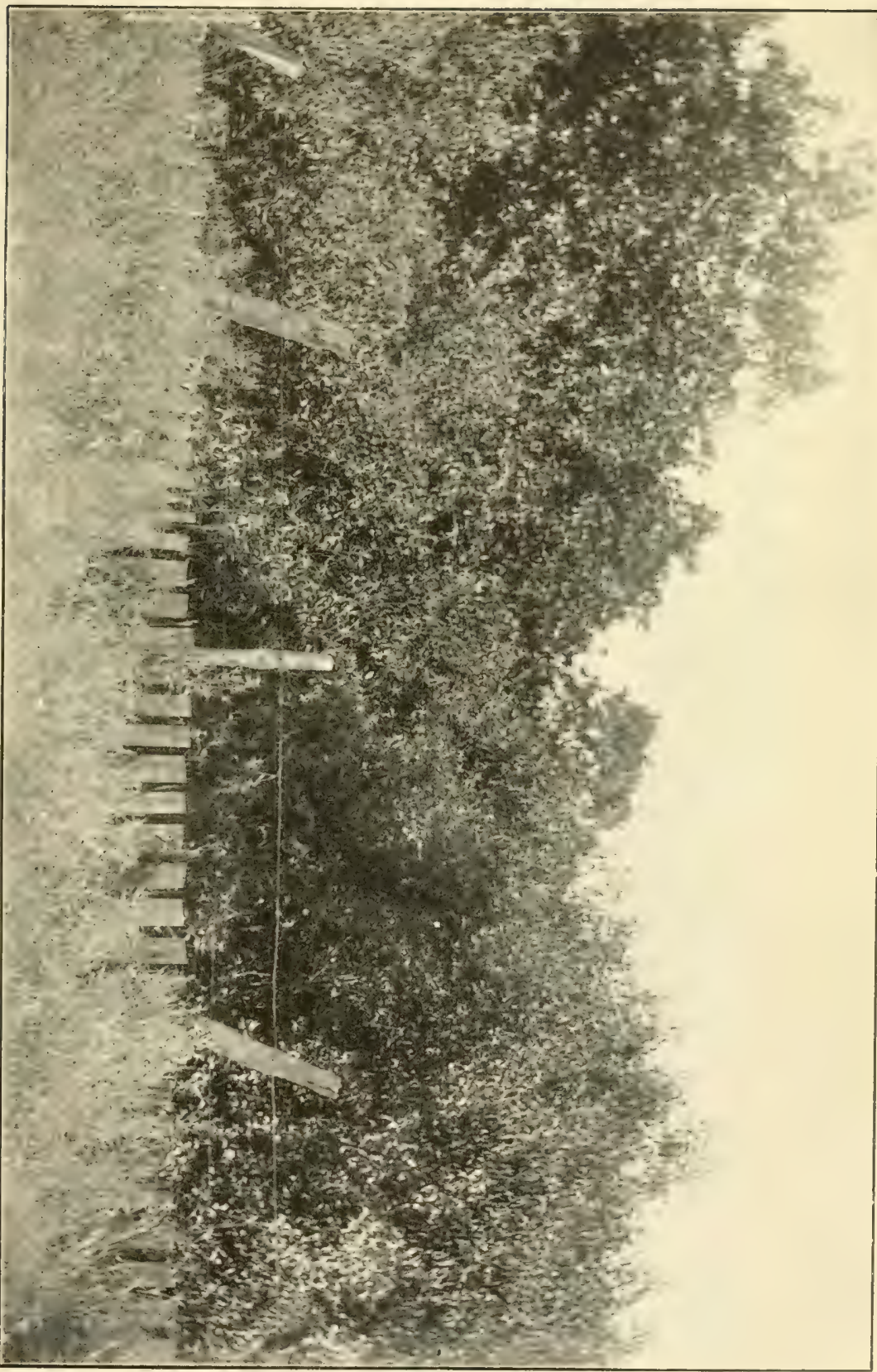





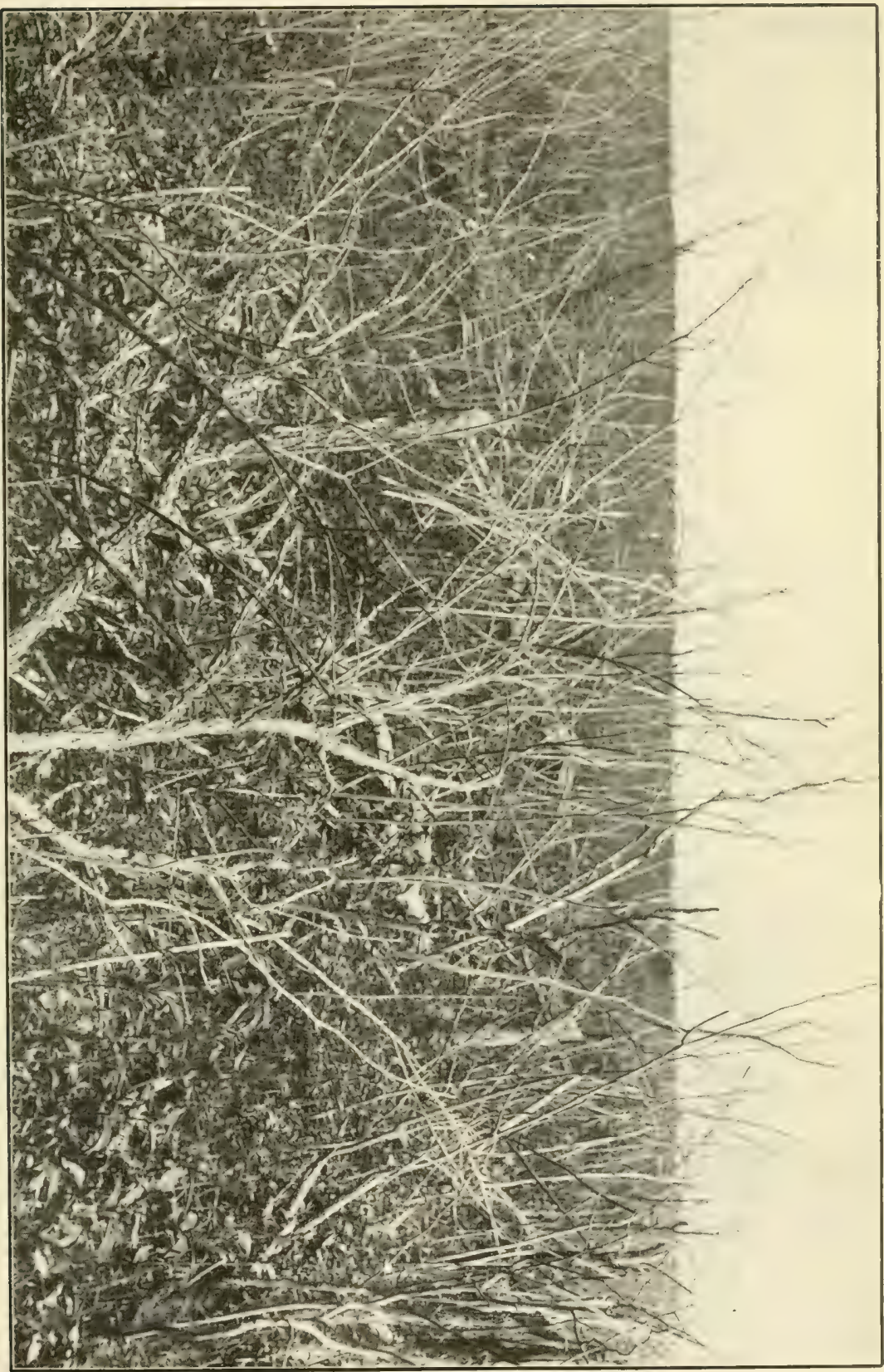





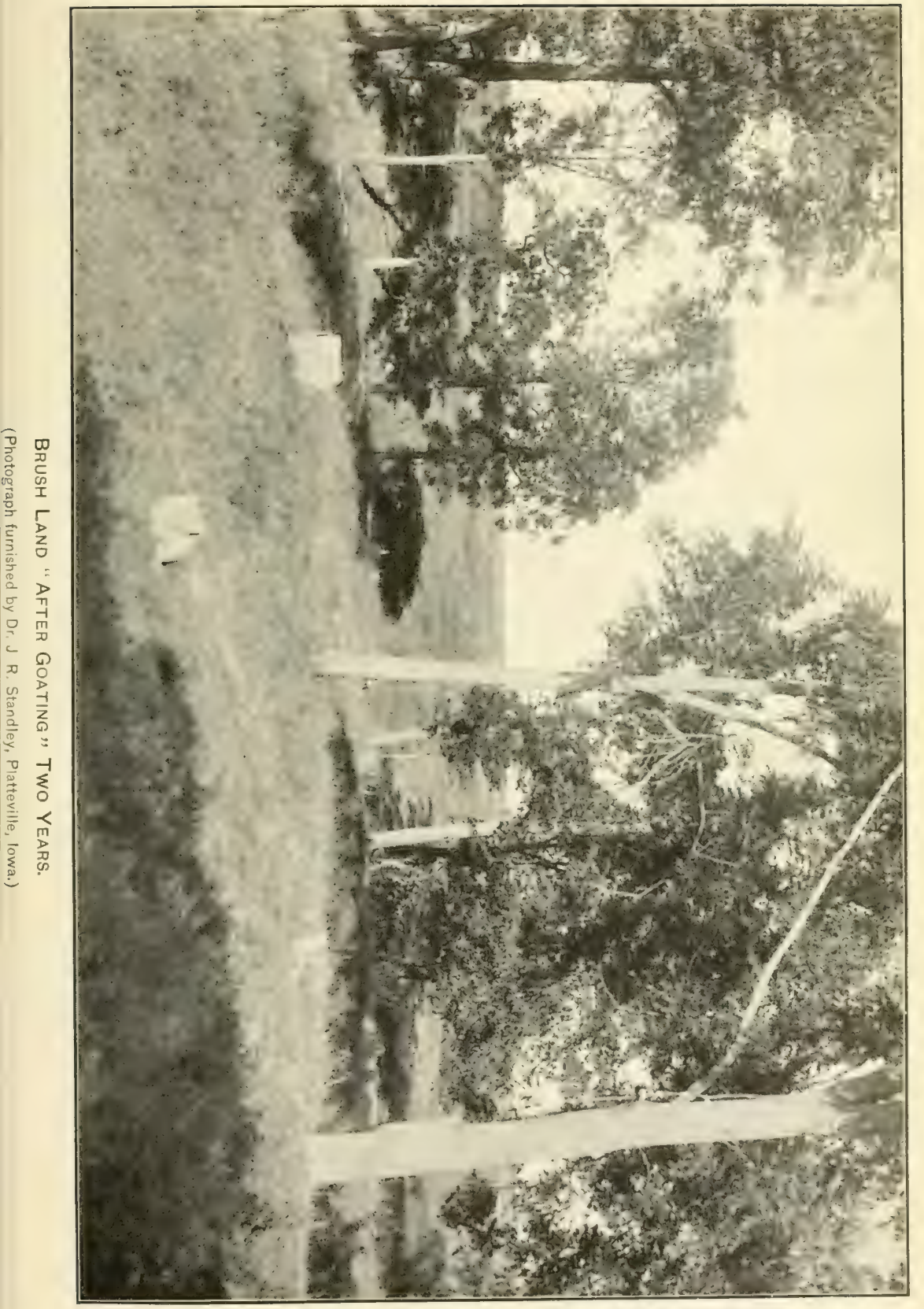



We have almost all kinds of browse in Arizona, but serub evergreen oak preclominates. We have millions of acres of it, too--Arizona.

Oak, hazel, ash, fir, and madrona.-Oregon.

Live oak, post oak, hackberry, elm, black persimmon, black jack, mesquit, mountain cedar, wild plum, etc.-Texus.

Several kinds of oak, sumac, grass, and weeds. They will eat almost any kind of underbrush.-Texas.

Brush, weeds, briers, mullen, and thistles.-Iowa.

All of the undergrowth common to southern Iowa-plum, hazel, four or five kinds of oak, elm, three or four kinds of willow, crab apple, and buck bush (sometimes called turkey berry).-Iowe.

Bromeing supplements ferdime - The browsing hathits of goats is important in connertion with the question of feeding. In some placess they ohtain enough howse to arry them through the winter. This is especially true in the southwest. Where there is so great an abundance of live oak. If snow is on the ground, or for other reasons the groats are deprired of opportunities for foraging. the trees are cut down for them. They pass though the winter in good condition with other feed. Wherever they are deprived of opportunities for hrowsing, they must lo forl. Browsing sares feed. As fal north as Terada Mr. Bailey's goate subsist the winter through on sagehrush.

Browsing adds game flavor.-It is noted that many of the correspondents heretofore quoted state that it is the hrowsing of the Angora that gires to the meat the game flavor, thus leading some to name the meat "Angora renisom." It is also stated that when deprived of hrowse and fed on orass and grain the game flavor disappears. There is no reason why this should not be true. for it is a well-known fact that fiavor may not only he fed into meat, lut into milk and egges as well.

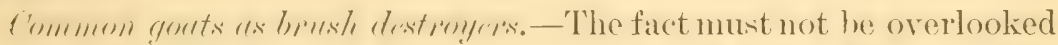
that the hrush-destroying hal)it is common to all kinds of goats. The common goats will do the work as well as the Angoras. The latter are employed for the purpose beasuse they are more plentiful and beause there is profit in their progeny for breding purposes. their mohair, and their meat.

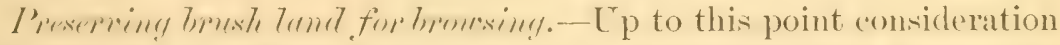
has been giren to these goats as a means of clearing land for pasture or for cultivation. There is much brush land in the United sitates which will support goats hut is good for nothing else. If this is to be deroted to goat raising. it is, of course, not desirable that the hrush he entirely exterminated. In this event a goat raiser should hatre sereral fenced areas and change the goats from one to the other frequently. 'They should not he permitted entirely to denude one field before they are transferred to another. It is true, however. that no matter how perfectly a wondland may be cleared of brush it will be $11786-$ No. $27-01--3$ 
corered orer again with hriers and bush in al few years if constant attention is not given it. It is not difficult to orerpalsture such lind, and if the geats atept the " peeling" practices the brush and trees will have greater difficulty in recovering.

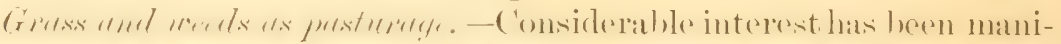

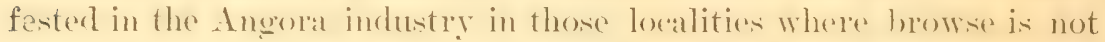
arailable and where gratsis and weeds form the only pasturage. A great many incuiries of this chatracter have come to the Bureatu, and the Burau, in turn, has referred the matter to the hreeders of the country: The replies recerived have been numerous, and show a differencer of opinions. The predominant opinion. howerers, serms to be that fhe genats thrive best under the conditions most nearly like those of their original home. It is certainly the best argment to sity that goate prefer any kind of hrowse to the most nutritious of eralseses, which is true, and therefore lorowse is better for them than garass. While the more comomical conclitions obtain where there is an abumdanere of hrower, it is not definitely settled that the geats will not thrive

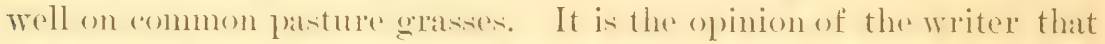
this question is still an open one, at some suedessful heresders have hat goats on the grase range for thirty years. From the standproint of the groat's preference, there is no question that browse is the better food, and this in itself is a forceful argument.

There is alwaysexpense in connerention with pasture grasses, but there is little or none with hrowse. One of the ehice reasons why geats are receiving so much consideration at this time is that they are pratetically inexpensive feeder's, and no all items of expense must be figured on if profit is to result. Parturage. unlike browse, is not aratilable all the year throngh. Therefore in prairio locations foeding in winter is a necessity. One of the recommendations in farol of Angora mutton is that it hats the flatror of renison. This flaror is imparted ly the browse, and is absent in the mutton made from grass or gratin feed. Many raim that the animals make a better growth amone the bushes

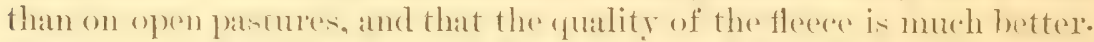
Contrary to this, howerere is the opinion of Mr. Philo Ogden, of California. who saly: "The fant is that the brush disalpueatre from my range and the fleceses become heavier. with less wax or gam, and hat more luster. Further, is pere cent of the young stoek are larger than their parents and shear more and finer hatir." He salys, also, that his experience in raising opersey cattle wats similar. in the respect that as they were taken ont of hrush pastuxage and grown oil grass pasturage they obtained a larger frame, so much so that sales failed because of a suspicion that they were not purebred.

Opinions of sereral correspondents of the Bureau are giren in the paragraphs following:

It is not advisable to raise goats for their mohair on farms on which they will be obliged to feed to a large extent on grass and forage plants which are suitable for sheep.-H. M. Williamson, Portland, Oreg. 


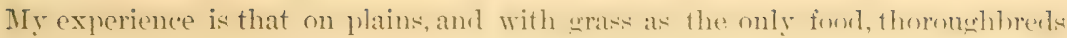
would not do well, while the lower grades may do fairly well so long as the altitude is sufticient. Usually the mohair is somewhat dry and coarse where grass is predominant.-G. A. Hoerle, Ridgewood, N. J.

Where there is grass and brush, they leave the grass and eat the brush. They prefer browsing.-Cook \& Buck, Oskaloosa, Kans.

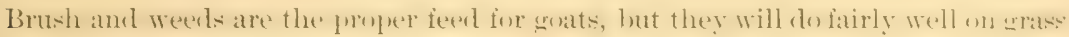
ılone:-Harris \& Baylor, Montell, Tex.

They must have some brush.-U. S. Grant, Dallas, Oreg.

Experience has proven that they will do as well on prairie farms as on any other place, but they should have artificial shade for. hot weather.-E. H. Jobson, Lulie Valley, N. Mex.

High-bred stock will do specially well.-T. Cladek, Lamood, Oreg.

They will do well anywhere that they can get green food.-Abe Blacklurn, North Yamhill, Oreg.

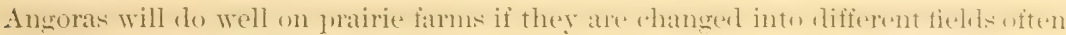
or have a large pasture.-Oscur Tom, Angora, Oreg.

They do well on prairie farms, but do better on bushy or hilly land. One of the advantages of Angoras is their adaptability to rugged bush land which is unfit for other stock.-C. P. Bailey, San Jose, Cal.

Angoras will do well on grass and weeds, but will do much better if they can get considerable browse also.-Josephus R. Barnette, Globe, Ariz.

Only in small numbers will they do well on grass and weeds, but where they are kept in large numbers they need a good deal of brush and timbered country. Of course, they will do well on prairie if they get some corn.-H. T. Fuchs, Tiger Mills, Tex.

They will do first-rate on prairies, where grass and weeds are the only pasturage; but they will then have to eat the feed which the other stock require, whereas, on

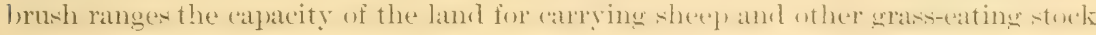
is not lessened by the presence of Angoras.- H. G. Hughes \& Co., Heistings, Tex.

I pastured two summers on grass and clover, and they did as well as when on leaves and weeds. I am confident that a farm cleared of brush can successfully be used for Angoras.-J. R. Standley, Platteville, Iowa.

They need a great variety of feed and rough range, with plenty of pure, clear water.-IV. T. ILcIntire, Kansas City, Mo.

They do well while the grass is green, but do not like dry grass or weeds, and always do better when they get some brush. They will have to be fed in winter on prairie farms. - H. I. Kimball, Maxwell City, N. Mex.

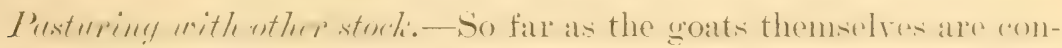
cerned, they may be kept in the pastures where there are sherele atttle, and horses. 'Their presence is in no way obmoxions to any of these animals. It has already been pointed out that a few of them in a flock of sherp are a protection against dogs. Howerere it is not hest for the goats that they he kept in pastures with horses. This is a deperally important if there are kids, as the horses hare a habit of platy fully chatiing any animal that is not lange enough to defend itself and they ane alyt to strike the kids. It is also important that the kids should not lee in pasture with hogs, which are liable to eat them. 
Vumble of youts to an ar\%. - This is a quation fropuently asked, but artainly no thoughtful person experts a definite answer. The number will depend, first, upen the object in pasturing on hrush land, whether it is to kill the hrush or to use it as a permanent pasture; and serond, mpon the quantity of fexel obtainable. While one acre might lu as dexse as a jungle, another might hare small thickets altremating with gass plats. 'Thus it will he seen that a definite answer an not be given to this question.

MOHAIR.

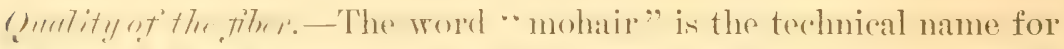

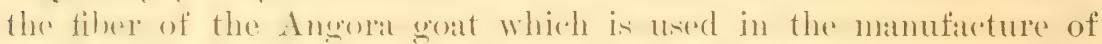
fahries. The word romes to us, through the old French "mohere," from the Arabic " mukhayyar," meaning mohair cloth.

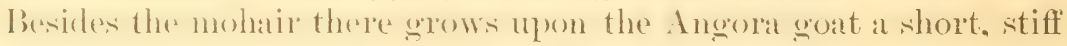

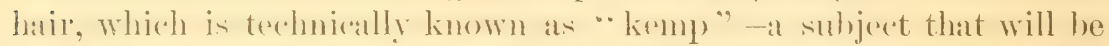
discusised in another paragraph. It is held by some writers that this

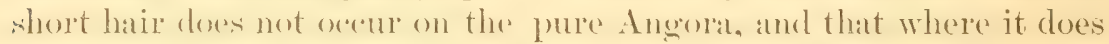

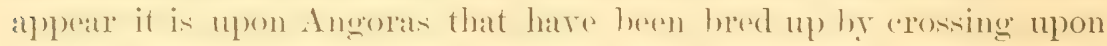
the common goats; in short, that it is a relic of the common goat. This algument sermin plansihle, at least, for two reasoms: First, there is no (ertainty that any ingora gats now in existence are alsolutely

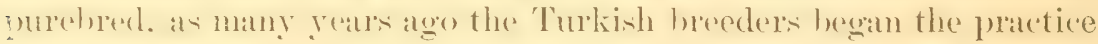
of ressing upen the Kurd gats. and thus vitiating the hood; serond,

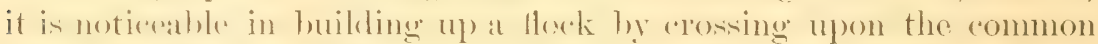
gonte that the short hate is very prominent in the first cross, and gradually grows less as the crosses become higher.

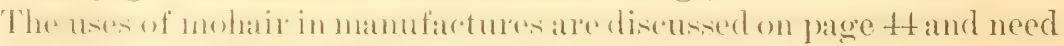
not he repeated here. 'The properties of this tiber which render it

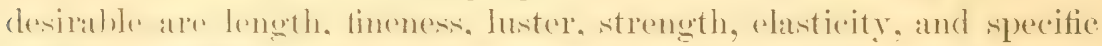

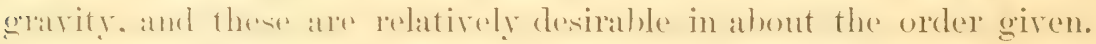
There is no difticulty in serming length and strength, lout the other porpertice must rome hy the most painstaking atre hy breeding. Having longth. Alengeth, and luster, the manufacturer wants the fiher as

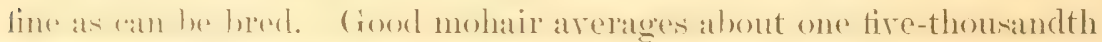
of an inch in diameter: or" expressed otherwise, 5., (n) hairs may be laid side by side in solid contact within the space of 1 inch.

Many mohair gromers asiont that the quality of the fiber depends

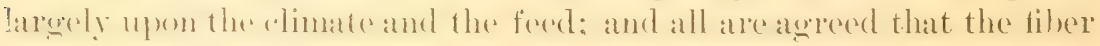
becomes coarser as the animal grows older. Schreiner says:

If goats are to produce the best fleeces they are capable of, they must be maintained in unintermpted good condition. They must have a variety of food, principally shrubs and aromatic plants, and lead an active life; they must, if possible, have running water to drink and be kept free from dust; they must not be kraaled (or shedded) except when absolutely necessary; they must have clean sleeping places and must not be crowded together. 
The wide range of priees of mohair in the matret is due to various eauses, but to none so much as the unevenners in guality of libers. As compared to the total production in the E'nited states, the quant ity of first-class mohair is exeecelingly small. The tendency has been to breed for length of fleece and size of animal. While both these qualities are desirable, it onght to be plain to anyone that profit does not lie in these directions wholly.

Iohair in a general sense is an expansive term, overing the fleceres

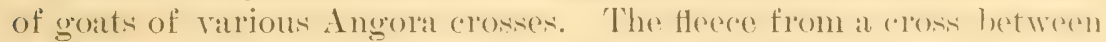
an Angora buck and the common "namnie," although scant, roal'se", and of uneven length. is unfortumately alled mohatr, just the same as that from the best animal. The fleece of the second cross is better. and that of the fourth and fifth crosies rery good. provided, al ways. that first-class bueks have been used. The complaint of the mamufareturer's is that very little first-clatis mohatir is predued in the I nited States. It hats been demonstrated, however, that a first-class finer can be produced here. Mr. Meekere, late eominal at IBradford. Eingland. the leading mohair market of the world. reecently wrote at follow:

There has been on exhibition at this consulate for the past week an Americangrown mohair fleece forwarded to Bradford by Mr. C. P. Bailey, of San Jose, Cal. The fleece is that of a 2-year-old graded doe and is understood to have been grown on MIr. Bailey's ranch in Nevada. The quality of the hair has been the wonder of all who have seen it. It has been closely examined by several of the leading mohair dealers and importers, all of whom have expressed the highest opinion of it. One of them, Jonas Whitley, ex-mayor of Bradford, said: "I have now in my warehouse about $\$ 200,000$ worth of mohair, both Turkey and Cape, and I am entirely sincere when I state that there is not a better Heece in the lot. I will buy all the American mohair like that that may be offered me at the market price. Should it uniformly equal this fleece, I do not know but what I would pay more than the market price. * * * I unhesitatingly say that the sample fleece is as good mohair as is grown."

A well-known spinner of New England is quoted by Mr. Bailey as saying that -

The American mohair is better than any brought from abroad; it is smoother, makes a smonther thesul, and rums spintles faster; it is silkier and wofter, and I can pick out cloth made from it without looking.

\section{Mr. G. A. Hoerle says:}

Samples of our best mohair which were sent to England were classed as equal to the best Turkish, while the best Cape hair was as much as 2 or 3 cents lower, a fact which proves that even if we finally should have to ship mohair to Europe it would, in the long rum, pay as well as selling at home.

Those American hreeders who have been taught to believe that the mohair of the Cape of Good Hope is so mueh better than that produced here will find encouragement in the following from Mr. . . . B. Itollings, writing to the Midland News, Bradford, England, meder date of April 27, 1900:

When I state that the rast majority of mohair clips produced in Cape Colony does not fill the bill of our manufacturers I state the whole and sole reason why Turkish 
sorts have been called upon very extensively in preference to that grown in South Africa. $* * *$ I am stating a plain fact that Bradford users do not think that the Cape elip is as yet within 25 per cent of the general excellence of that grown in Asia Minor, and that much remains to be done before users here will avail themselves of that produced in Cape Colony in preference to that grown in Turkey.

The encomberment is not in the faet that the (iape molate is so mule porerer than the 'Turkish product, but because ours is no worse than that of the ('alpe. Although the ammual product of the ('ape of

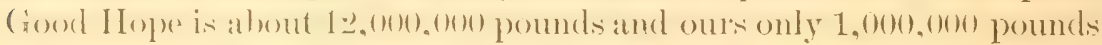
approximately. the growers there recognize the importanes of the Ameriean industry. Mr. W. Hammond Tooke, after discusing the Anstralian pessibilities in this industry. says * the Enited sitates of Americat should give us more comeern." In the same article. published

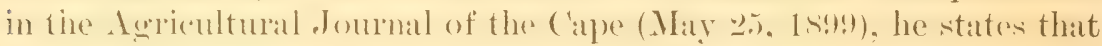
the herecling of goats here for mohair is no longere considered an experiment, and that the mohatir is - much like a large part of that produced in the ('alpe, consisting of lather low grades, short and crosshered, and only suitahle for combluation yarns and for mixing with 'Turkey hair."

As illustration of the superior value of the mohate from Angora vilayet and calpe of frood Hope, the following table and statement are

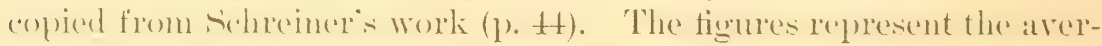
age of the four years 1891 to 1894 :

\begin{tabular}{|c|c|c|}
\hline & Angora. & Cape. \\
\hline Mohair goats.... & $1,230,000$ & $2,891,233$ \\
\hline Mohair ............ & $3,360,000$ & $9,982,709$ \\
\hline 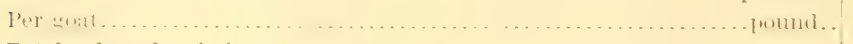 & $22_{4}^{3}$ & \\
\hline Total value of mohair . .................................... & 200,000 & 419,501 \\
\hline 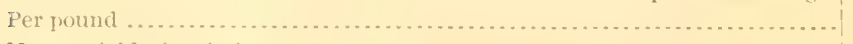 & 1s. $2 \frac{1}{4} \mathrm{~d}$. & $a 10_{11}^{1} \mathrm{~d}$. \\
\hline Money yield of mohair per goat .......... & 3s. $3 \frac{1}{5} \mathrm{~d}$. & 2s. $11_{4}^{1} \mathrm{~d}$. \\
\hline
\end{tabular}

a Nearly.

The superiority of the Turkish hair is at once apparent, there being a difference in its favor in the above figures of nearly th. per pound, and also a difference in its favor in the net return per goat of nearly td., although the Turkish goats shear three-fourths of a pound of mohair less per goat than the Cape goats.

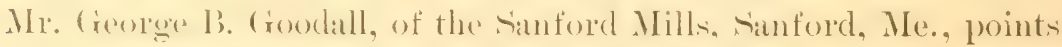
out. in a reent letere to the Burraue the defoets of the Americangrown mohair taken as at whoke. IJis mills consume more than a million pomolis of mohate ansmally. some being the domest ic product and some the Turkey produet, and thus he speaks from latge experience. He says:

before the domestic mohair growers can expect to get anywhe near Turkey prices they must do away with kemp and aim for a fine stapled hair instead of breeding for coarse, heavy fleeces, as many do. The coarser the fiber, the lower the value to the spinner. We often get small shipments of domentic tleeces as choice and tine as 


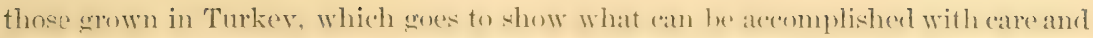
brains. The trouble is more with the grower than with the goats and the climate, for what one man can do another can do.

There are in these quotations hintsenomgh to point the propere course for those goat ratisers who desire to make their mohair areple a paying one. If an Angora goat is of most protit in clearing land of hrush (as is the catse in some localities). his work will he dome just as well if he

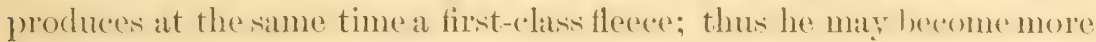
valuable. 'There is no reason why Ingoras should have the preference for such work orer the eommon goats, exeret that they may he protitahle in other respects at the sime time: therefore the better the fleece produced while destroying hrush, the greater the value of the groats.

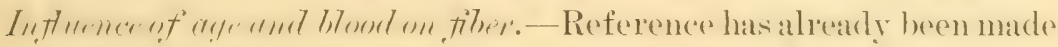
to the fact that the fiber becomes coarser as the animal grows older. The fiber is also coarse upon younger animals of the lower crosices. 'The best fiber grows upon the animals of hest blood: and among these that wpon kids. yourling wethers, and does, in the order named, is pre-

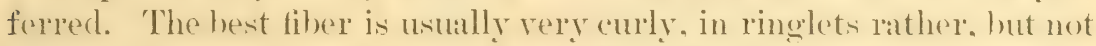
kinky. It loses itseml and hereomes thinner on the goat, coatrser, and straighter as the animal grows older. A fiber of best quality is shown on the left of Plate $V$. It will he noticed hy careful examination of this illustration that the samples bocome less curly as arranged from left to right. The reason for this is that the samples are coarser toward the right. The last sample in the illustration is from an old huck, the one next to it from an old doe, while the two simples on the left are from kids.

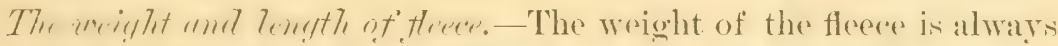
a subject of inquiry and is a difficult question to answer. berause of the controlling cilcumstances-such as climate, feed, are. and, ahove all, the degree of Angora blood in the animal. 'The hriefost answer', anc probably the hest one that can he mate in a general way, is that of Mr. C. P. Bailey, and is as follows:

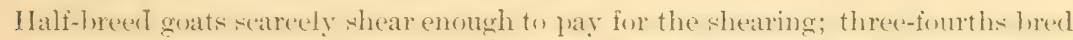
goats shear 1 to $1 \frac{1}{2}$ pounds, worth 15 to 20 cents; seven-eighths bred goats shear 2 to

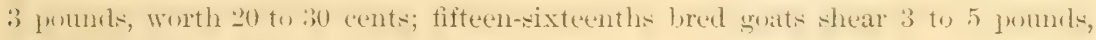
worth 30 to 40 cents.

He adds the important statement that the fourth rross, or fifternsixteenthis, is the lowest grade that he would use "xelusively for mohair.

It would be a difficult matter to state what is the arerage length of an ammual fleece. hut 10 inches would probahly not be much out of the way. 'There is on lecord an account of mohair measuring zo inches. Mr. L. A. Grant, of Oregon, reports a huck with a fleece 1 ! inches long. In the southern part of the country, where shearing is done twice a year, the fiber must necessarily be shorter. 'This is a disad- 
vantage, as the spinners prefer a long fiber. Schreiner shows (p. 119) a picture of a buck carrying a 1:3-months' fleece, weighing 16 pounds, which touches the gromd. The feet of the animal are just visible.

The weights of the Heeces in the United states are much greater than in Turkey and about the same as in the Cape of Good Hope. With reference to Turkey, Schreiner says: " It would seem that 14 pounds for rams and si pounds for ewes are albout the maximum weights of really first-class fleeces, and that if these weights are much exreeded the quality of the hair is inferior and a good deal of the weight is due to oil and dirt." In the Cape of bood Hope buck fleeces have surpassed 15 pounds and ewe fleeces 11 pounds. Information at hand indicates that the arerage weights of fleeces in Oregon exceed those of other sections of the eountry, especially in the warmer portions. 'This reminds one of the opinion of colonel Black, that the fleece will be increased 1 pound in weight by moving the goats to the colder Northern States.

schreiner says that the goats must not he arowded together in quarters if the best fiber is to be ohtained, and Hoerle says that "goats rumning together in small herds will shear from 25) to ti per cent more than when ruming in large herds." The size of flocks is discussed in another place (see p. 75).

The influence of semiammual shearing upon weight of fleece is also discussed elsewhere (see p. 76 ).

Ke-mp. - The term " kemp, " used in comnection with mohair refers, in a collective sense, to the coarse hair of the goats, and is especially noticeable in the lower grades. Itoerle says: " Kemp) is the coarse, dead-looking hair all through the mohair, alwout z to 4 inches long, which I consider to be the degenerated remnants of the long, coarse, dead-looking outer coat of some commong gats. It is usually thickest on the hind quarter's of hadly bred goats." Its presence in mohair always reduese the price in proportion to the amount that is present. 'The reasons for this are various --the hair is coarser than the mohair"; it is lusterlesis: it is of valious short lengths and must be removed, in doing which there is a heary loss of mohair; and it will not, except to a linited degree, take the dyes used for mohair. This last statement is a striking fart and ought to be the means of prompting the mohair growers to strive to breed it out. Whether or not it can be done entirely is an open question, hut it is believed by many prominent breeders that it can be done. Shehreiner. howerer, (consider's kemp) a part of the fleece that can not be eradicated completely.

C. P. Bailey \& Sons Company say:

Kemp is a coarse white hair which grows from a separate root sheath between the mohair and is usually thickest upon low-grade goats. It is most noticeable along the backbone and around the tail and upon the thighs. We have never seen a goat entirely free from kemp, nor have we ever seen molnair irom any part of the world 


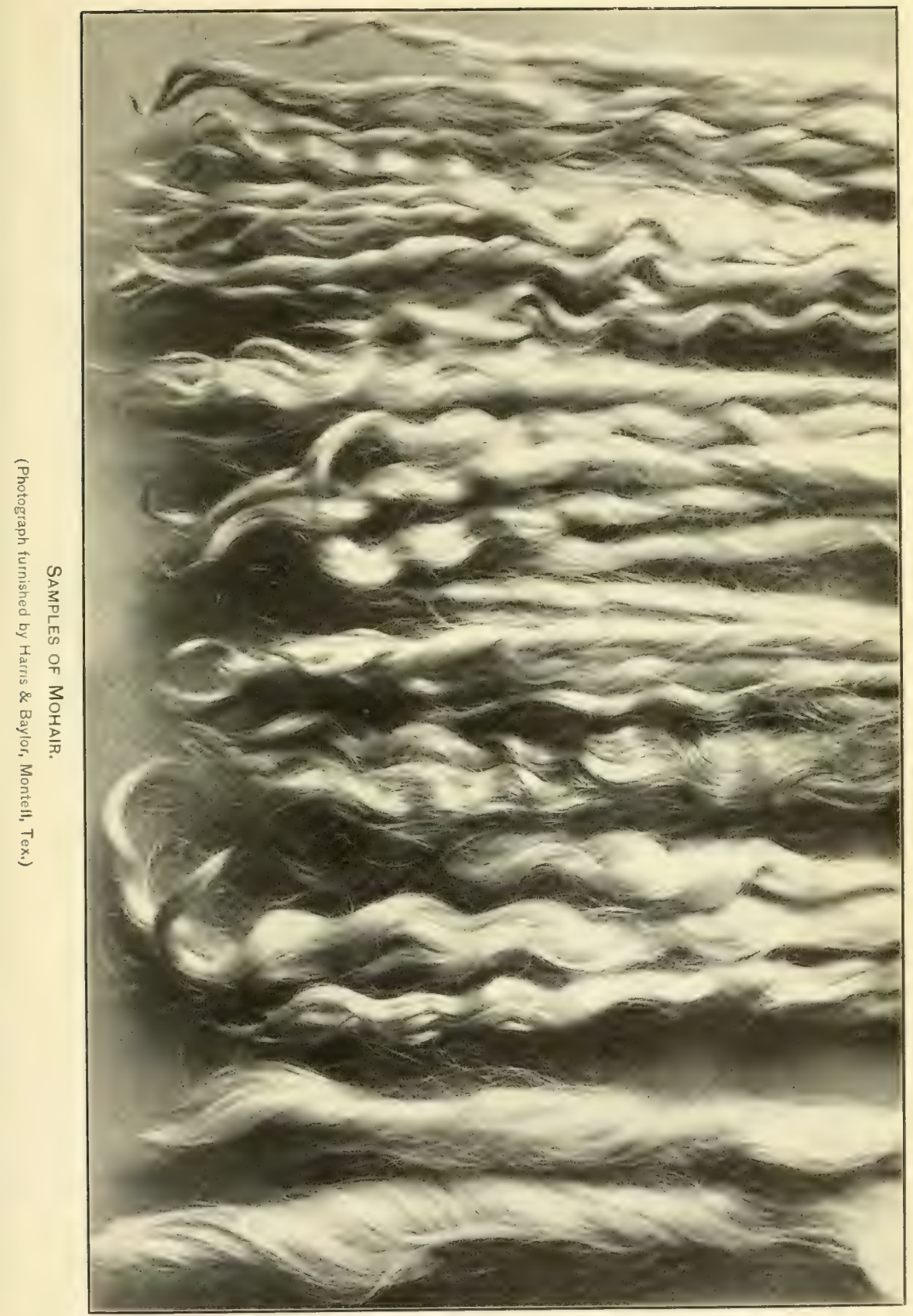






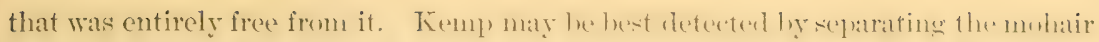
upon the thigh of the animal and closely inspecting the roots of the hair. It will he

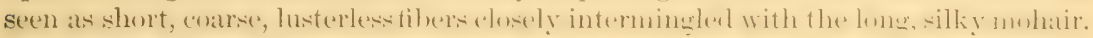

After the mohair sorter has dome his work with a fleces the filure is

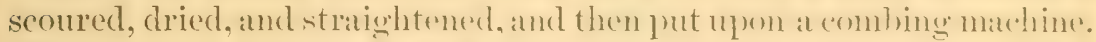
This machine, sepatrates all filurs, whothere of hemp or mohair, of t inches in length and under. Kemp) of a gereater lemeth than \pm inches remains with the longere mohate. If there is much of this long liemp)

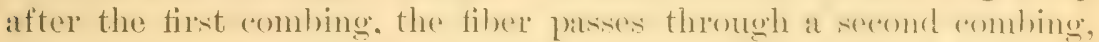

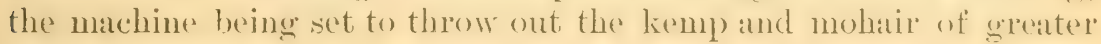
length.

The residue of these two (ombings, heing a mixture of kempl and

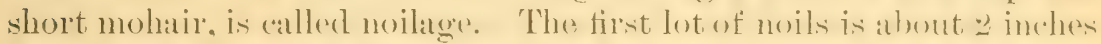
long and the second $t$ or more inches lomg. 'The leneth of the serend noils will vary with different grates of nohair, depending num the length of the kemp present.

Some mohair will shrink $t^{\prime \prime}$ pere "ent in weight in the first (a)mbing

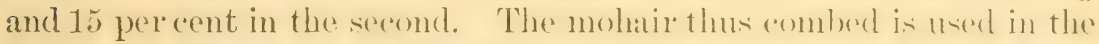

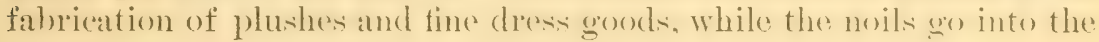
manufacture of carpets, blankets, hats, etc.

In a recent article in the ()regon Agrioulturist, Mr. (romper: B. Goodall says:

A majority of the mohair growers in this country little realize how much kemp has to do in keeping down values of their clips. If they could spent a few hours in our sorting and combing rooms the lesson learned would be of great value to them-more than could be obtained by reading. In watching the combs at work they would notice some making 5,10 , or 12 per cent of noil or waste, while others will be taking out 30 or 40 per cent. Ask the comber the reason of this and he will reply that one lot has a much larger amount of kemp than the other. One fiber of kemp takes out five or six good fibers which should go into yarn. It may not generally be known why kemp is such an objection, but when we state that it will not take color, but remains nearly white in the gures ater pasing thromgh the rlye bath, you will understand why I write so strongly on this point. If you want to form some idea of how a fabric looks made from kempy mohair yarn, just look at a man's hair that has commenced to turn gray, especially dark or black hair.

Through the kindness of IIr. Goodill the IBurean of Animal Industry has received some samples of low-glade plushes for atr seats

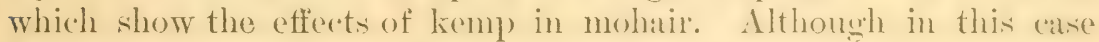
dyes were used which acted tosome extent upom tho himp), the coarse,

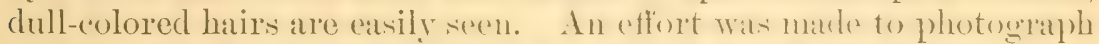
the samples for leproduction in this paper, hut it wats imposible to bring out the details sufficiont to show the kinp), althongh it was plainly visible, under certain lights, in the plushes.

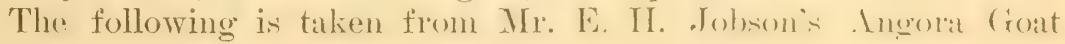
Raising:

In the first crossing of goats the kemp hair will be paramount in appearance with the mohair and will be very coarse, and as the animal becomes better graded the shorter the kemp will be, and it also gemerally lecondes of a finer tiber as the gure 
houl is inficed. Upun examining the hest grame of guats that we have we find that the kemp is very short, probably only three-fourths of an inch in length, and the mohair on one of these goats is 8 inches long and weighs 5 pounds, while the kemp on the second goat is just as scarce and of the same length; also the mohair is of the same length, but the weight is fully 2 pounds more than it was on the first goat: herein lies the difticulty. Both goats have the same appearance so fur as examination can determine, but the second goat is inferior to the first because the fiber of his hair is much coarser than the other and contains more of the kempy blood; hene the rlitliculty in examination alplears in the ynality of the til wer, which can he detected only by an experienced eye.

The kemp hair will always be known by its being shorter and very coarse and of a chalky-white appearance. It is particularly noticeable on account of its having no luster, which is characteristic of all mohair. The first place that kemp becomes extinct on a goat is on shoulders and neck-i.e., on the sides and along the ribs-and the last place for it to become extinct is along the top of the neck, down the backbone, and on down to the hocks, the hocks being generally the final place for the disappearance of the coarse hair; also you will find kemp to predominate on the belly. Do not understand me to say that the kemp becomes entirely extinct, for it does not, but it is covered up with the mohair and can be seen only by throwing the animal down and examining him carefully, and if he is apparently free from kemp you can examine him on the places above mentioned and you will invariably find more or less kemp, and generally you will find considerable all over the body. A good way to examine the hair is to pull out a small lock and spread it ont in the hand, and you can readily discern any coarse hairs that may be in it. It is supposed by the best authorities we have that there are no goats in the world that are abso-

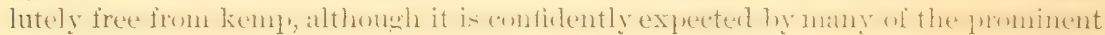
breeders that it is ouly a question of a few years more of careful breeding until we have a kempless goat.

In addition to the abore. Mhe Jolson writes to the Thurean his oplin-

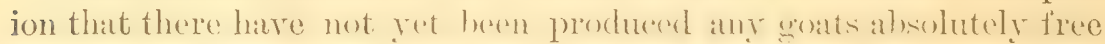
from kemp, hut he belieres that the intelligenes of the Anerientus will enable them to ponduce such goats. and he himself proposes to devote sereral years to the allort. Ile proposes to bregin this work mpon the assmention that there is mowhere an absolutely pule Angerat goat -that there is at present in all of them in some degree the hlood of the common breed.

The diseussion of hemp) will alose with quotations of the opinions

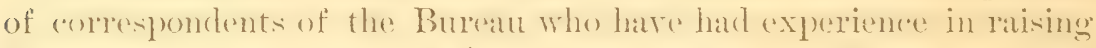
Angoras. It may be stated that a latgere majority of these men hold

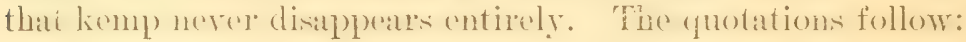

I don't think that there are 500 Angoras in the United States, thoroughbreds or crossureds, that are entirely free from kemp. Judging, however, from what I have seen in former years, freedom from kemp can exist, even with second and third crosses, provided the right kind of common does are mated with really kempless bucks. Such experiments were made with bucks of the. Price Maurice importations to Australia, of which one buck and two does came to Texas. Mr. Schreiner, the Cape Colony authority, says that none of the pure bloods (so called) imported into Cape Colony from Turkey were free from kemp, and, further, "that kemp can and will be entirely eliminated from our [Cape Colony] best stud goats of our most intelligent breeders I have no doubt whatever," with which opinion I fully agree.G. A. Hoerle. 
In all crosses it will still remain, to some extent at least, on some parts of the body; for instance, on the belly.-H. T. Fuchs.

It will never disappear.-IIarris \& Baylor.

If only the pure-blooded Angoras are used as sires, kemp will be imperceptible in abont six or eight generations.-Col. William L. Black.

There is but little in the very best.-Abe Bluclibum.

There is not much after the first cross.-Oscrr Tom.

In the fourth cross it nearly disappears, but never entirely.-C. P. Bailey.

I can not find kemp in my thoroughbreds, although I have found it in billies that I bought for pure. I think it can be bred out with proper care in selection of billies.-George A. Houck.

(other deleterions fienture. -The very short hair. mane, kemp, and the hair that has heren ent twice in shearing are, togerther, called noils. and this must all be combed ont hefore the moluail cam bes spun. The

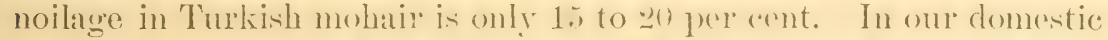
product it rums as high as fll per ant. Noils ane worth only $1 t$ to 16 cents a pound, the same as short wool for blankets.

In some sections of onx comtry. Where the limate is dry and the soil distinctly alkaline, the natural animal yolk disilppeats from the mohatr, leaving it dry, frowsy, and harsh. 'The dust of the fine alliali soil pemetrates the firecer, so that much of the mohar grown in those sections is loaded with it, anomnting in some instances to to pere cent in weight.

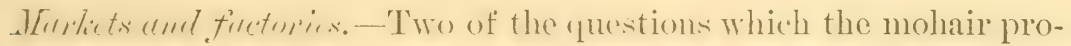
ducers were asked to answre ware: - I) you have any difliculty in

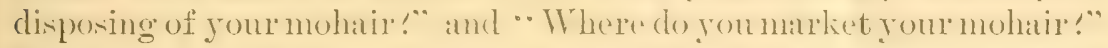
The auswers to the first question were all fimly in the negative exeept in one instance, where an Arizona producer lerplied: " I have no difticulty in disposing of my goud mohair, hut my shoit and hempy stock goes slow and at a low price (2:3) c(2nts)." There is much encouragement in these replies to those who may fear that the malkets may not demand the supply. The ingenuity of the manufacturers in working the better grades into woukn fithries and the poorer grames into plushes which make good all suits, horse hlankets, hats, ete., has, no doulst, opened the way for the consumption of all that may be produced.

As to factories, there are more than at sufficient number in this comntry to manufactures the product; in fitet, mimy of them do not attempt to nse mohair for the reasom that the supply is so limited. There factories of the ['nited States are all in the Fast. and the principal market for the mohair is New York. 'The manketing anter of the world is Bractord, Fughand, where practically all the product of Cape of Good Hope and Turkey is sold.

Very few of the wills will purchase direct from the producer. 'They 
find it preferable to buy from the commision merehant. as he sepa-

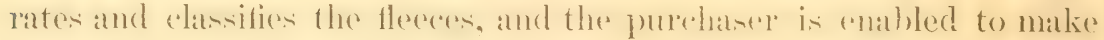
persomal inspertion. A few producer's ship their molnatr to Boston, and other's, esperditly some of those in the Northwent, sell to commission men in Portland, while others of the Wrest sell in tan Jose. Call.

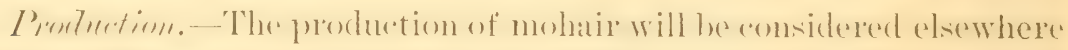
(ree p. se) in connection with the world's production and the imports and exports.

\section{MANUFACTURES OF MOHAIR.}

One of the reasons why the mohair industry hate litegerd so in this country during the tifty years sines the inteoduetion of Angora goats

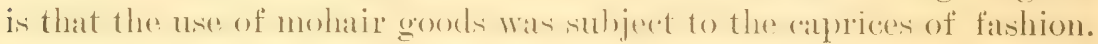
It would not be strietly eorrect to say that the industry hats erengot beyond the influenere of fiahion, lut it is at least nearly so. There is now a steady demamel for the prodent of onr conntry, and murh is imported besides. Dame Fashion is still whimsical toward all-mohair goods, especially dress groods, hut the mohair is mixed with other fibers for producing fialories of strength and lustere, and the home supply is not nearly explat to the demand. Becallone of the limiterd and uneretain supply, some mills which hatre at times used mohate no longere attempt to secure it. They are prepared to use it ats som an the supply will warrant the undertaking.

Mr. Greore E. Condall, prexident of the simford Mills. Sinford, Me.. who hat kindly furnished the Bureau with valuahle information,

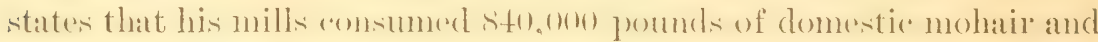

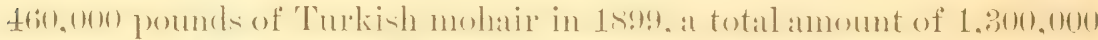
pounds. While these mills alre believed to due the larerest consumers of the domestie product, there are themsinds of pounds consumed by other mills (see p. s.2). This provess, first, that there is at good demand for mohair, and serond, that the monal extimate of the domes-

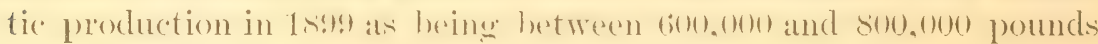
is far below the real amount.

Only a small percentage of the domestic product of mohair is of superior cuality, as hats heen shown in prerious pages. The greater amount is of inferior quality fom virious caluses: First, the fleece

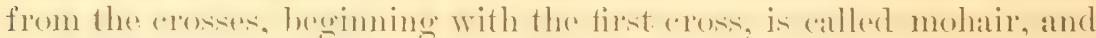
is indered worth something; seroud, all of the alosises up) to the fourth

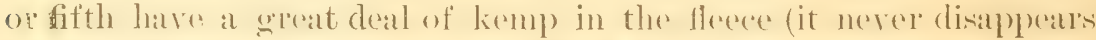

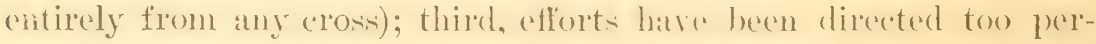
sistently toward producing a latere fine-lowking animal. the fleece being a secondary (onsideration; fourth, the staple, when of superior quality, is often too short.

Many grades of mohair are mixed with silk and wool in a large variety of fabries in which it formerly wats not used. It is wade into 
dress goods known as mohatir. and murh of what is ustatily anlled

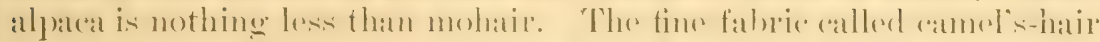
goods is also of the hest mohail. and not from the "amele as wo would

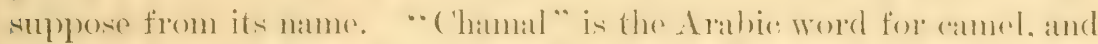

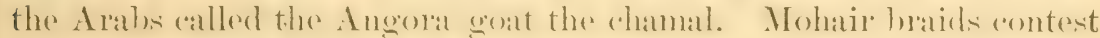
the makets with silk hrats and are never ont of fashion. 'The ways in which it is tserel with silk and wool are mmmerous. It adds to thesese fibers not only its lnilliant imherent lustor. but great durability as well. The erowers of mohair are fond of quoting I)r. I)aris. who

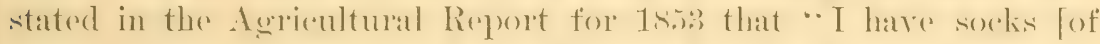
mohair] which I hate woln for six rears and ale vet perferety sound." Ite is alse quoted as saying that while in Asia he salw watpperes of mohate nsed hy the natives which, they assules him. hard desernded from sire to son for three generations.

Mr. William R. Payme an authority, is quoted helow on the uses of mohair:

The most important product of the Angora is the long, silky, wavy fleece, used either pure or in connection with wool, silk, linen, or "carlton" in a variety of fabrics for house furnishings and ladies' goods, brilliantines, linings, braid, plushes, astrakhan cloth, furniture coverings, curtain material, knit goods, fancy effects in shawls and dress goods, and numerous other textiles. * * * The short, low, and crossbred hair is used for blankets, lap robes, rugs, carpets, and low goods generally, but even then is worth more per pound than most sheep wool, varying from 10 to 21 cents per pound. The uses for mohair are increasing every year, and new outlets are being found for it as manufacturers are advancing in the variety of their products.

THE MEAT ANI) THE MARKETS.

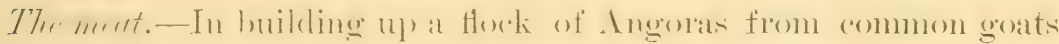

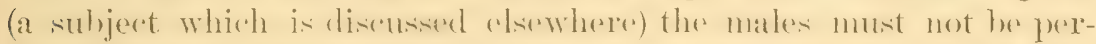

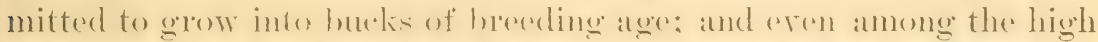

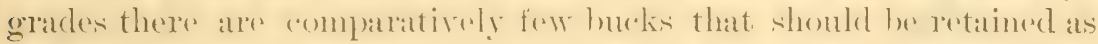
such for hreeding purposes. They shoulel be castrated atrly. The

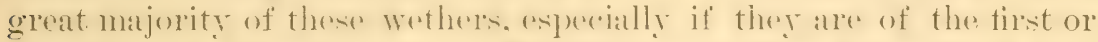

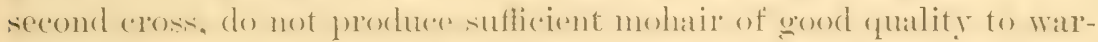

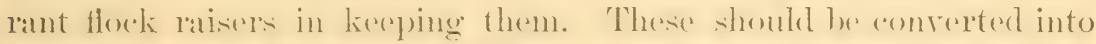

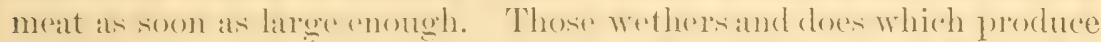
a fair quality of mohatir may he restained for that prupose for a fow rears and then killal for meat. 'Ther alpe not. howerer, so good for this purpose as the younger animals.

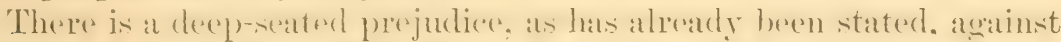
the use of goats of any kind for meat. This is fomoled mon ignorance rather than experience. The most ill-smelling " hilly" of the worst posithle ty pe is hy mamy made the standaled of gate meat for

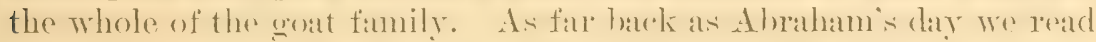
of goats leing used for meat (rery likely Angoras), and this, too, when 
there were many eattle and sherp). ('ortainly no prejuclies existed against them at that time.

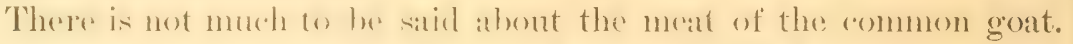
It is not so enenerally ward as that of Angorats. The flesh of their kids is considered very fine, and in some sections of the country goats of all ages are killed for meat. There are comparatively few common goats in the ITnited states, and no attempt is being made to put them upon the markert. The current report that goats are sold to the packers in the larege aties for amming purposes is true in the main, but refer's to the Angeral grater. The discusion of this question in this paper deals with the Angoras of all grades.

The flesh of the Aneorat is exeredlingly nutritions and palatable. Shropshire lambs, which arenomsidered as amome the best linds of meat, are raid not to be suberior to a wrell-fed and well-conked kid. In the Southwest these animids are ar readily wold for meat as sherep, and the

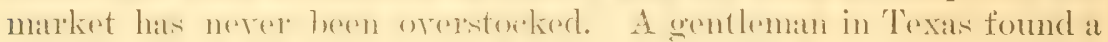
ready market for his cammed Angera mutton. hut wats compelled to

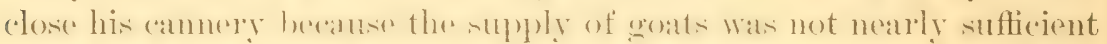
to supply the semand. In the Northwest the principal we of the

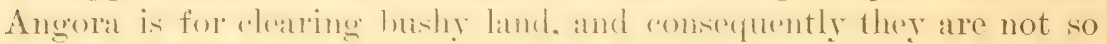
extensively used as food. However, in nearly every locality there rome have been killed for muthon, and the pre has never heen a derogatory stutement conerening it quality. wo fall as the writer is able to learn.

In (atpe Colony it is said that the old does are slaughtered to furnish meat for farm hands and young wothers are sold to butehers in the town. In (alifornia many miner's purchatse Angorat wethers in preforence to shere wethere for silting down for winter use, because, an they state, the Angora contains less fat. is more easily liept, and is just as palatable.

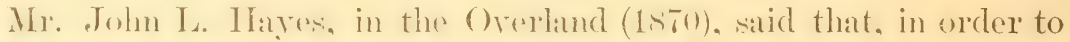
test the qualities of Angerat and sheep mutton, an dinner wats to be prepared with the two kinds of meall. and that the guests were not to he informed as to which was sheel and which wat goat. but they were to decide upon the merits of the dishes.

Twelve disinterested men were invited to partake of the dimner and express their opinions of the various dishes they had eaten. Four decided in favor of the sheep's and eight in favor of the goat's flesh; and since that breeders in Monterey County have no difficulty in selling their goats to the neighboring butchers for the same price paid for the best mutton.

Mr. F. II. Johsome of Lake Valkey. N. Mrex. is authority for the statement that the wealthy perple of st. Lendis reently began eating roung Angerar mutton an! that it in now a regular portion of their fare. 
One of the guestions to which the Bureau someht replies is at follows: "In your opinion, what are the retative ralues of Angera flech and mutton!" Sereral answers to this question, with other quetations upon the same subject, are given herewith:

As a food there is no meat that is purer or more tender. It is better than mutton, as there is not that excessive fat to contend with that is found on sheep. This is a good feature in the Angora venison. In their feeding habits they are very similar to a deer, which alone is sufficient proof of the merits of their food qualities. A young kid is as dainty a morsel as can be found in the meat line. The wealthy people of St. Louis recently took up the fad of eating young Angora venison, and, as a result,

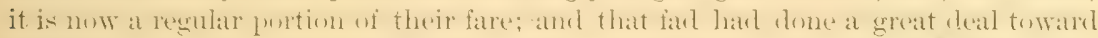

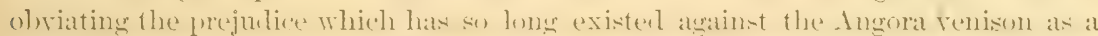
food. Angora mutton is now being sold on the market at a fraction of a cent less than sheep mutton. - E. H. Jobson, Lake Jalley, N. Hex.

If Angoras are castrated or spayed when early kids, and properly fed before marketing, and if this is not done too far away from the slaughterhouses, certainly not more than a two-days' ride (road travel), their meat is fully as juicy as Southdown mutton, while, on the other hand, it is never greasy. This is not only my experience in Texas, but was also that of MIrs. Sarah K. Barmore, of Rockland County, N. Y., who kept a flock of grade Angoras and sold the progeny to her neighbors, principally summer residents from New York City. She emphasized the point that her customers preferred it to ordinary mutton, because it was not greasy. Feed Angoras as much as you choose, they will never lay on fat in thick layers all through the meat, as in the case of other domestic animals. They gain, rather, like deer, in meat principally, which has a slight venison flavor.-Gustav A. Hoerle, Ridgewood, N. J.

It is a curious fact, but true, that black-haired animals have darker skins and

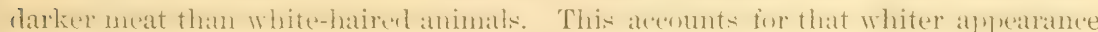
of the Angora goat flesh, which enables the dealer to market it as mutton. The black hair, from a poetic standpoint, casts its perpetual shadow on the viand and leaves it shaded. The goat fiesh is a pleasant and healthy meat. It should be so,

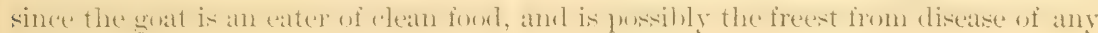
quadruped.-Queensland Agricultural Journal, STay, 1900.

The flesh of the Angora goat is said to be superior in flavor to that of any mutton. We have eaten several half-bloods and found thiem delicious. Some of the meat was -put on sale in a local meat market, and the purchasers came back a few days later and wanted more good mutton like that they got the last time. This, we think, is a strong recommendation. The meat is juicy and sweet and has a game flavor.Miller \& Sibley, Tenango County, $P \alpha$.

The Angora is nueh more mutritions than sheep mutton, especially where the meat

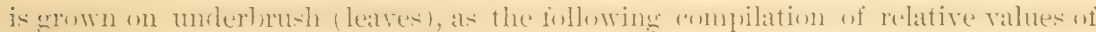
feed will show:

\begin{tabular}{|c|c|c|c|c|}
\hline & Character of feed. & Protein. & $\begin{array}{l}\text { Starch, } \\
\text { etc. }\end{array}$ & Fats. \\
\hline & & Per cent. & Per cont. & Per cent. \\
\hline (inurl laasture arian & & $\therefore .5$ & 4. 7 & 0.. \\
\hline Rich pasture ...... & & 4.5 & 10.1 & 1. 0 \\
\hline Leares of trees.... & & 5.2 & 15.2 & 1.5 \\
\hline Red clover......... & & 3.3 & 7.0 & 0.7 \\
\hline
\end{tabular}


It is often prescribed by physicians for invalids and children for this reason. The meat is excellent, and not clistinguishable from mutton of the same age and condition. It is largely sold as such in many of the larger markets, being regarded as a staple in the districts where it is raised.- W. G. Hughes \& Co., Ilastings, Tex.

It is the universal testimony of those who are familliar with Angora goats that the flesh of this animal is far superior to that of the common goat. The Angora is quite as valuable for its flesh as for its fleece.-Oregon Ayriculturist, Portland, Oreg.

The meat from Angora goats is fully as good as the most juicy mutton. This meat is sought now more than at any previous time.-Kansas City Drovers' Telegram.

Anybody who has ever tasted a roasted or barbecued piece of Angora mutton will find it is better than any ineat they ever tasted. Angora mutton is worth in the markets about the same as sheep mutton. I sell it to my neighbors at $4 \frac{1}{2}$ cents per pound, and in town I sell it at 5 and 6 cents per pound.-H. T. Fuchs, Tiger Mills, Tex.

It is better than mutton, being free from the oily taste of sheep meat and partaking somewhat of the flavor of wild meat.-George A. Houck, Eugene, Oreg.

Angora mutton is far superior to that of sheep and brings just as much on the market. Being free from disease, why not?-Josephus R. Bamette, Globe, Ariz.

Superior, as they live principally upon leaves and weeds, which gives to the meat a game flavor.- Wr. T. Mc Tntire, Kansas City, Mo.

It takes an expert to tell the difference; and, if there is a difference, it is in favor of the Angora.-Harris \& Baylor, Hontell, Tex.

I believe it is superior in that it is absolutely pure, with no superfluous fat, and is as tender as the finest of venison.-E. H. Jobson, Lake Valley, N. Mex.

I prefer the Angora or common goat flesh to that of sheep, though I have seen many people who could not tell the difference.-II. I. Kimball, Maxwell City, N. Mex.

I consider one as good as the other.-Abe Blackiurn, North Yamhill, Oreg.

Young goats are fine meat, but old wethers are tough and strong, although good when boiled tender and served cold.-Oscur Tom, Angora, Oreg.

The young wethers make the best of mutton. The meat is rich and juicy and free from the strong taste so common to the meat of the common goat. I consider it equal to mutton. We have sold hundreds of head for mutton, always reserving the skins, which are worth green from 75 cents to $\$ 2$ each.-C. P. Bailey, San Jose, Cal.

I think one is equally as good as the other.- - . T. Waln, Salem, Oreg.

Angora is very much the best.-U. S. Grant, Dallas, Oreg.

It takes an expert to tell the difference, or to tell Angora mutton from venison where the goat had access to brush.-Cook \& Buck, Oskaloosa, Kans.

I value Angora mutton 50 per cent above sheep mutton.—V. Cladek, Larwood, Oreg.

Angora flesh is worth 12 per cent more than mutton.-Richardson Bros., Dubuque, Ioreer.

It is preferable to mutton, as it does not have the woolly flavor so objectionable to many people. During the browsing season the meat has a venison flavor, but this is lost when corn is fed in the feed lot.-R. C. Johnston, Lawrence, Kans.

I am sorry we have no regular market for goat meat. It is as fine as venison when killed in condition and properly cooked.-TV. Brown, Salem, Oreg.

Local butchers will pay 10 cents per pound for the carcass dressed, the seller retaining the pelt, which brings \$2.-I. If Gorem, Libby, Mont. 


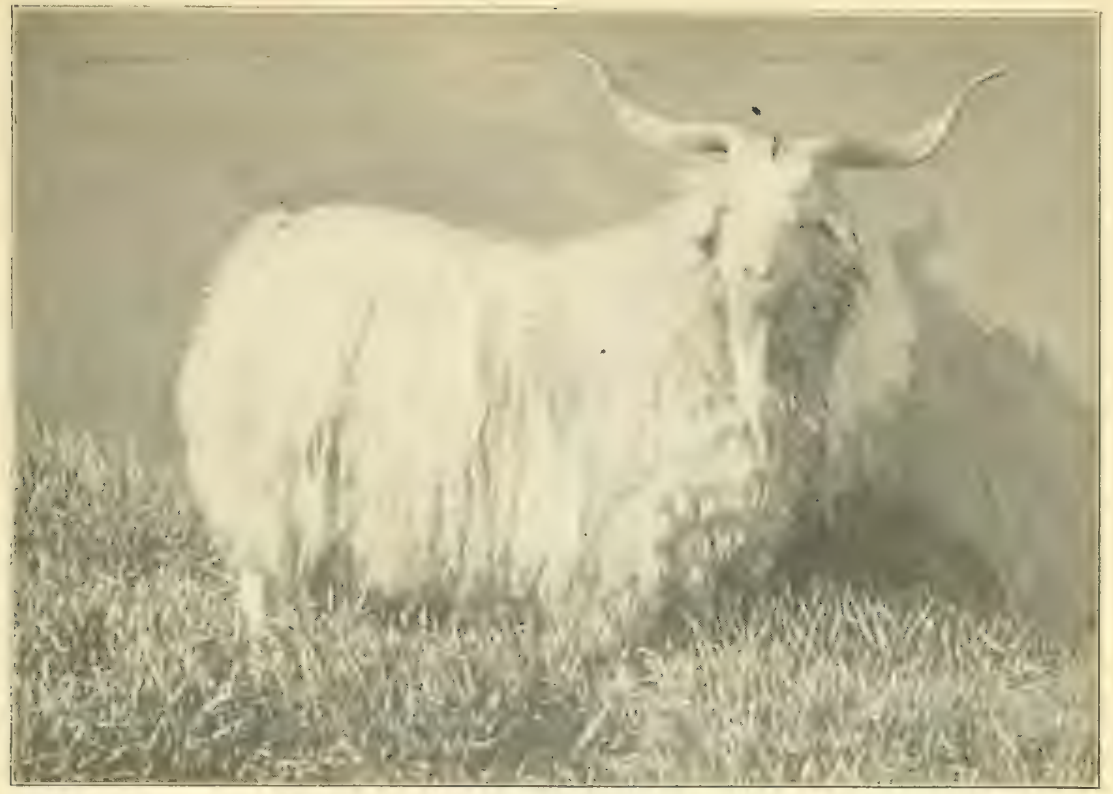

FIG. 1.-ANGORA BUCK "PASHA."

(Photograph furnished by C. P. Bailey \& Sons Company, San Jose, Cal.)

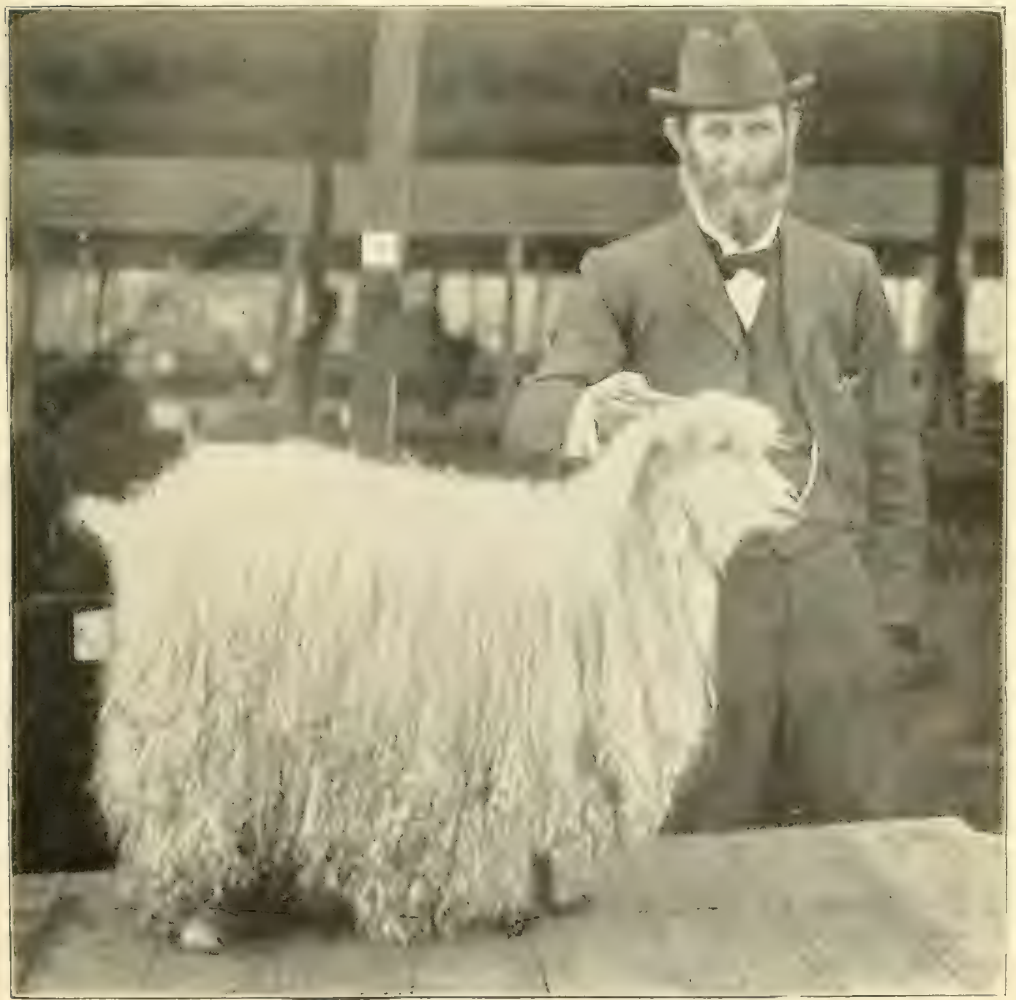

FIG. 2.-A YEARLING ANGORA IN CAPE COLONY.

(From the American Sheep Breeder.) 



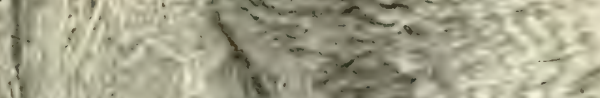

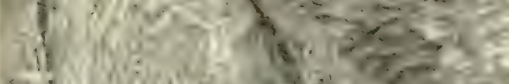
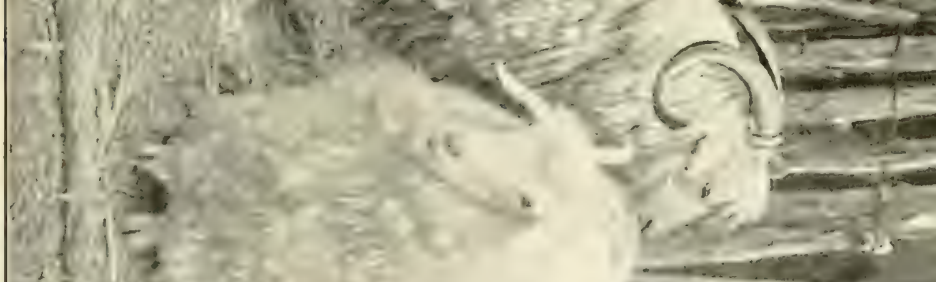

(0.6.

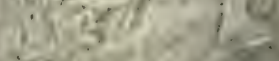

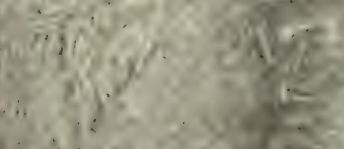

.

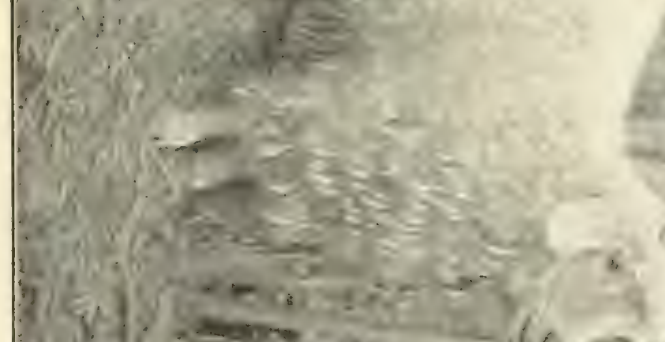
(1)

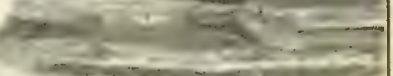

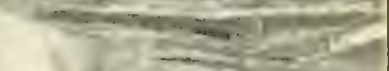

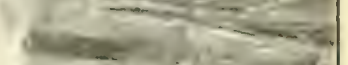
$2.5-3=0$

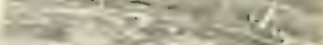

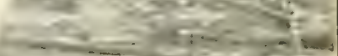
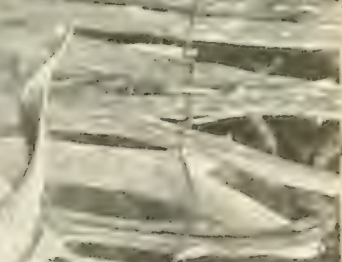

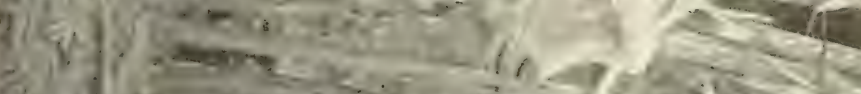

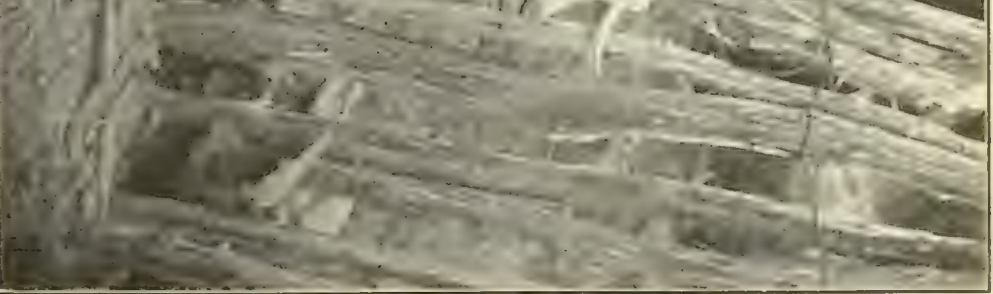



The merticts.-One of the first questions to be considered by a man who is about to embark in stock raising of any kind is the markets for his surplus. This question is first hecause it is the principal one and all important. The one who proposes to hegin with a flock of thoroughbred or high-grade Angoras, such as will yield merchantable mir hair, will not need to comsider markets, as the increase will be cmployed to produce molarir; hut a large number of flockis will he huilt up in the future, as they have been in the past, by the use of does of the common breed. This method will necessitate getting rid of every wether for two or three years. All does, of course, are kept for breeding with purebred bucks. It will be ascertained that the fleece of low grades is barely worth the cost of clipping it: that the skin is not so valuable for leather as that of the common goat: and that, as a rug or robe, the pelts are not so valuahle as those of the higher grades. Therefore, if there is to be any profit from this part of a flock, there must be a market for the meat.

So many questions concerning this phase of the industry have come to the Bureau of Animal Industry that, in collecting data for this paper, it was decided to go beyond the newspaper accounts and ascertain the fatets from the actual producers themselves. 'The question submitted was, "Do you have any difficulty in disposing of your surplus Angoras for meat?" "The answers have been invariably in the negative. It should be said, howerer, that in the Northwest rery few are used for meat. They are considered more valuable there as brush destroyers. The conditions obtaining there are not found in all localities where Angoras are raised. In many places Angoras will be kept where, instead of permitting them to destroy the brush utterly, efforts will be made to preserve brush pasture for them; in the southwest they are not all required for dentroying hrush. and thousands must be sent to market.

The reason why goats are not seen oftener in the market reports of receipts and shipments is that they pass as sheep. It is stated, however, that increasing numbers are seen in the larger markets. In the Union Stock Yards of Chicago as many ats S. $(000$ were received in one week last year.

While the goats pass as sheep, they are also sold to consumers as sheep. They have not yet brought as good prices as sheep, and it can not be hoped that they will do so until there is the same demand for their mutton, which will come as soon as the prejudice against goats disappears. The difference is very slight in some places. In Kansas City, for instance, the sheep bring about one-half a cent per pound more than goats. The packers buy them as goats and sell them as sheep in the form of dressed meat or canned.

11786-No. 27-01-4 
Some of the answers to the question summitted ly the Burean are appended:

You ask if I have any difficulty in disposing of goats for meat. None at all. The packers here buy goats as goats and sell them as sheep. They make a difference of about half a cent a pound in favor of sheep when buying, and, as they never sell goats, they save that difference in selling.-Thomas H. Mastin, Kansas City, Mo.

None whatever.-IV. G. Hughes \& Co., Hastings, Tex.

Angoras bring now in Kansas City and Chicago within 4 or 5 per cent of the price of ranch sheep, while ten or twelve years ago not half that much could be obtained. Were it not for their unpopular name "goat," the meat would bring by far the highest prices in the retail narkets-provided, of course, that they reath the market. in proper condition.-G. A. Hoerle, Ridgewood, N.J.

I sell readily at the four large markets within 25 to 40 cents per hundredweight of the same grade of sheep. They are purchased by the packers. They dress out more meat than sheep.-K. C. Johnston, Lawrence, Kans.

We do not have to dispose of them for meat, as there are parties always anxious to buy. We would have no trouble to dispose of them for meat if we wanted to.-Richardson Bros., Dubuque, Iowa.

We do not. It usually sells for a little less than mutton.-C. P. Bailey, San Jose, Cal.

There is no sale here for goat meat. Wethers are generally used for their mohair or clearing land of brush.-Oscar Tom, Angora, Oreg.

There is not much use being made of them except for clearing land. A few are occasionally slaughtered here.-Abe Blackburn, North Yamhill, Oreg.

The demand for mutton goats is greater than the supply. We get good values for the mutton.-E. H. Jobson, Lake Valley, N. Mex.

They sell as readily as sheep, but bring from 25 to 50 cents per hundredweight less on the market.- IV. T. McIntire, Kansas City, Mo.

None sold for meat here.- V. Cladek, Larwood, Oreg.

So far all goats are wanted for clearing brush land, and there is no trouble in sell. ing them.- IV. Brown, Sulem, Oreg.

We have a local market which can use three times as much as we produce.Josephus R. Barnette, Globe, Ariz.

Never had a surplus yet, being in demand at fair prices for clearing land.-George A. Houck, Eugene, Oreg.

None at all. If fat, the packers will buy them rearlily. If not, the sheep feeders will buy them for fattening.- William L. Black, Fort IC Karett, Tex.

Have not. Have used and sold very few for meat, as they are in demand as brush killers.-J. R. Standley, Platteville, Tour.

None at all. I could sell hundreds and thousands as easy as I could sell sheep.H. T. Fuch, Tiger Mills, Tex.

We do not, but on account of a prejudice against the name "goat," we have to sell at about 50 cents less than sheep bring.-Conklin Bros., Newville, Cal.

THE MII,K.

The Anerera is not primarily a mileh goat. and is not often employed for that purpose. 'The information at hand indieates that the guantity of milk wiven hy an Angora doe is uncertain, and only in exceptional 


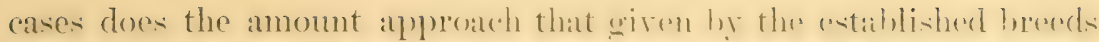
of mileh goats. such as the Togerenhureg. Malta, and Nuhian hereds. some of the records of the atrlier importations of Angoras inter the Cnited states show that some of them were milked with sueness. At this time, howerer, they are not rexemmended as mileh gonte: they are more useful in other lines. It is stated upon the authority of some of the oldest breeder's in the country that the likeliheod of tinding a good milele goat among the Angorats diminishes as the grade of the goat is raised. The milking yualities evidently come from the side of the short-haired goats.

The quality of Angora milk is anid to be exual to that of any othere breed. and more nearly equal to human milk than that of any othere animal. For this reatson it is considered the best sulstitute for motheres milk for infants. An analyois of goats" milk for the British (roat society, with an analysis of "ows" milk for anpuarion. is shown in the table below. It should be stated that the cows milk was ferom i! cow which was a winner at a dairy show.

Comparison of analyses of goats' milk and cous' milk.

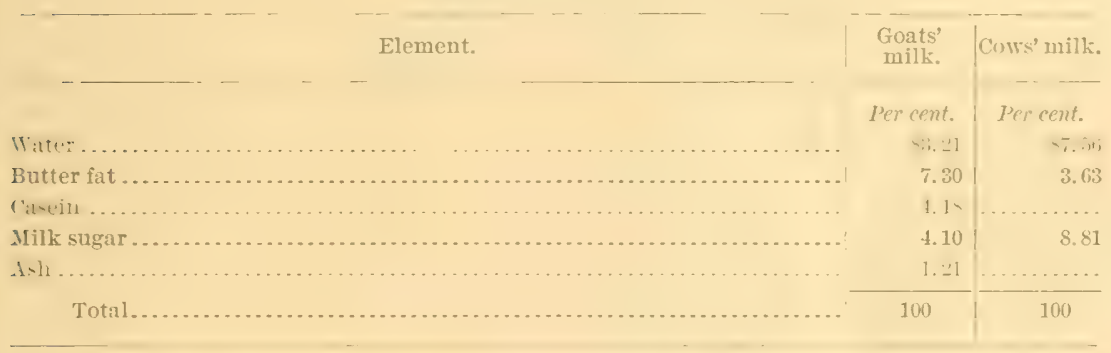

The milk hats an additional value in that the animal is pratetionll:

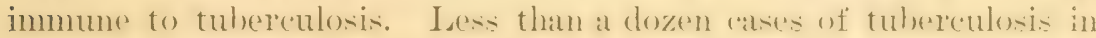
goats are recorded.

THE SKINS.

The use of Angora skins, other than for robse. rugs. and trimming as described helow. is not rery extensive. The kin in of a more delieate

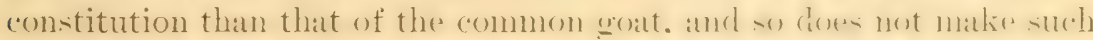

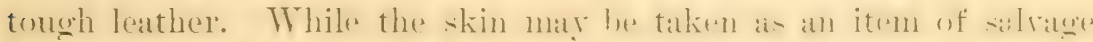
from an animal that has died or heen lilled tore meat. it would mot be protitable to raise them for leather alonte. If sueh -kinn latplyen to

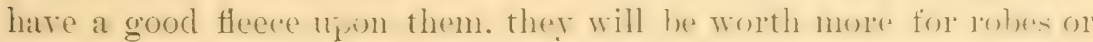
rugs, but eren then they would not he protitable alone. The me must the othere sourees of profit in ardition to the skin. Angeral skin-are manufactured into morocere for use in binding bork- and exedlent

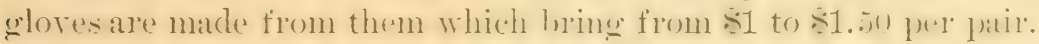

An impression is widenpreat. lated upon immature consideration. that Angora skins may soon supplant the great number of gorat-kins 
which we now import for leather, but the guality of the skin predudes any surh possibility. L'pon this point the Oregon Acrieulturist salys:

It is a natural mistake to supunses that Angura guatskins are worth as much, promd for pound, as common goatskins. We have several times noted the fact that this is not the case. Angora skins, after the mohair has been sheared off, will bring only a little over one-half as much per pound as the skins of the common goat.

The only way to keep at home the greater part of the money now sent abroad to pay for goatskins will be to raise enough common goats in the United States to supply the demand.

Iides should be kept rean and should be dried in the shade; sundried hides atre worthless. If the skins ale to be tamned soon after being removerl, they maty be silted. If they are not to be tamned soon, they should be dried.

\section{ROBES, RUGS, AND TRIMMINGS.}

Angerat pelts are used quite extensively ats carriage robes, and they make mp interery handeome ones. There was a time when the hutfalo, the wolf. and other wild animals supplied the demand for robes in this country, hut the extinction. practically, of the buffalo and the great scarcity of the other animals has fored us to look elserwhere for suhstitutes. An effort is being made to substitute hides of the Galloway and Polled Angus hreeds of cattle. hut their high cost will prevent their extensive use.

These conditions have resulted in a greater demand for Angora skins for rolues. The skin is sufticiently tough for the purpose. and

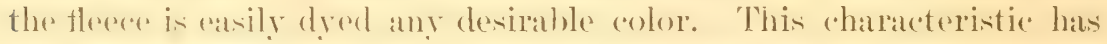
enabled unserupulous dealers to sometimes pass them off on purehasers as the skins of some rane animals. In their natural color, the whiteness and intlliancy of which can not he exeelled, the skins of the kids and younger does are made up into robes for baby carriages. There are probahly a greater number used for this purpose at the present time than in any other way.

As a general statement it may be said that Angora pelts are worth from se to sos. The real value depends upon many things-such ats the size of the skin. the length of the fleese upon it, and the time of year that it is taken.

As rugs these skins are found in many households. and they are both ornamental and durable. They maty he uwed in their original whiteness. or be dyed any color to suit. Their softness makes them rery desirable.

They are extrusively used for trimming for children's cloaks and

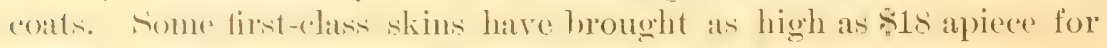
this purpose.

Mr. William R. Payne. of New York ('ity, who has had much experience in handling goatskins, says: 
Angora skins properly drescel are need, whiteor tinted, to manufacture rugs, robus,

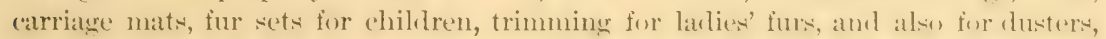
horse head taseds, doll hair, and wigs. They are mostly infortenl raw from c ape of

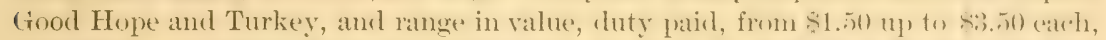

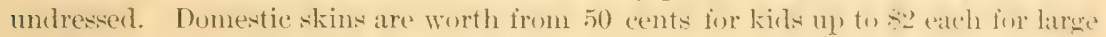
full-fleeced pelts. The low, erosthed, common skins and short pelts not suitables to

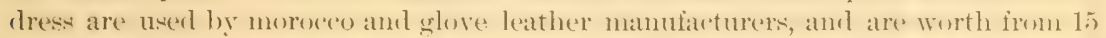

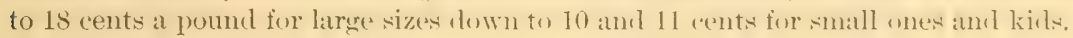

PROTECTION FOR SHEEP.

The ahility and inclination of the buck to fight varmints has made him in many places a valuable acquisition in herds of sheep. It is said that dogs and wolves will not only not attack a grown goat, but will not venture into a herd of sheep where there is a buek goolt. Mamy owners of sheep in this country recognize the value of the goat in this respect, and keep one or more for the purpose of protection for their sheep. This practice is especially desirable in pastures where there is no herder or immediate oversight. If one or two goats are placed when young in a herd of sheep they will remain with them all the time. An extensive breeder of Pennsylvania says: " While goats do not frar dogi, and will even fight, I prefer to keep dogsout. I hatreseen them drive a dog out of the yard, and oftentimes a single goat will protect aflock of sheep from attacks by dogs." If they are old and not accustomed to being with sheep, they will in all probability keepe to themselves, away from the sheep. They may be depended upon to do this certainly if there is cuite a number of them. They are more rapid walkers and more inclined to wander than sheep), and so will flock by themselves. Their protection to sheep will thus prove a failure.

It is quite amusing to see the courage of a doe when she protects her young kid from a dog, or hog, or flock of buzzards. 'Two of my neighbors' dogs got in the halhit of killing my kids, and one doe protected her kid guite a while from the two

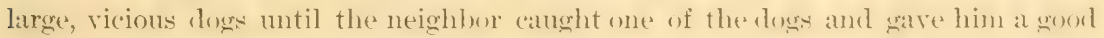
whiplung, when the gout aswisted in this work by butting the dog with all her might. Fon should train the goats to be hrave by taking your dogre into the gorat pen with you, and, in case the dog refuses to run from a brave goat, scold the dog to make the goat think that she whiperl him. If you harl a tame woll traines in that way you could train your goats to fight wolves. $-H$. T. Fuchs.

ENRICHMENT OF LAND.

The enrichment of land from the droppinge of goats is dereidedly noticeable wherever they are kept for al year or more. 'This farter is of no small importance where goats have been employed to char the brush from land with the object in view of turning the land into gratis: pasture. Such land, especially if hilly and rocky, is usually in need of fertilizers of any kind if eropping is to be attempted upon it. The manure of goats and sheep is about equal in value. I california firm has been selling Angora manure for fertilizing fruit trees 
and lawns for sereral years. They eret ste a ton (delivered) for it in carload lots. Manure is considered as one of the resources in the best system of moder'n firming, and it should be taken into account by anyone who is keeping goats or contemplating doing so.

THEIR USE AS PETS.

The purehred Angoras are rery eraterul, and their beatutifully shaped bodies and fine silky hair make them rery attratetive. There is no animal. except possibly the horse, that is more beatutiful than thesereats. and no animal is more cleanly in his habits. As pets for rhildren they are very popular. if they an be kept where they will be bambese to regetation and anything made of choth. They have all the propensities of the enmmon geat for destroying fruit trees and chewing any kind of eloth and of elimbing upon roofs. All kinds of geats are mischievous in the extreme. The Angoras are tractable and are often harnesied to carts. ats ale common goats. and their beauty makes them more desirable for this purpose.

BY-PRODUCTS.

In the modern methode of exomenie production and manufacture nothing is permitted to go to waste. Whoerer it was that sitid facetionsty that the parker's sised erery portion of a hog hut his squeal spoke the whole truth. The same truth applies as well to the careass of any fored animal. In the case of genats the horns find many uses, and the fat is sided to be the best tallow known for the manufacture of canclles. Any part of the carcals not now ful in any other way is converted into fertilizer.

LOCALITIES ADAPTED TO ANGORA CULTURE.

CLIMATE.

Sof far at temperature is conererned, no plate has been found that is too hot or too cold for Angoras. Althomgh not partial to heat, they will stand it quite as easily ats sheep. Shade is resential to suceess if the sunshine is very warm.

The clinter in Angerat, where the hreed originated and is still sup)pored to flourish in it more perfect state, is extrenie. A temperature as high at s. F. in registered in the summer and as low as a $\mathrm{F}$. in the winter. In cale of frood Hopee where they are thriving well, the temperature seres higher in the summer. but not sol low in the winter. The L nited chates presents a wider range of temperature, where, in southern 'Texile and New Mexico, it may go above 100 F. in the summer, and in Idaho ats low as :30 F. below zero in winter. 'The range of localities where Angeras have dene well is from ciltadalupe Islands,

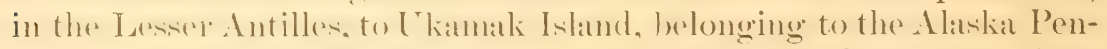
insulit. Mr. M. L. Wishlourn, superintendent for the Alaskat Com- 
mercial Company at Kadiak, says: *On Ukamak Island we hare a flock of Angora goats, which hate incereased bot pere cont a reate since they were placed there. They have griven rery good results in mohair, which is of good quality and fine texture." "There are a few small flocks in New England and in nearly every Ntate west until the Pareific Orean is reatehed. The Western States have many thomsands. Ir. IVilliam M. Landrum is quoted as follows:

White goats can stand any amount of cold and snow, but sleet and wind are very injurious. On the other hand, they can endure the scorching heat of the Tropics.

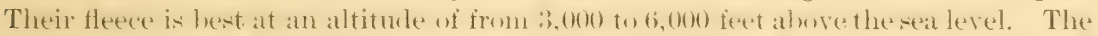

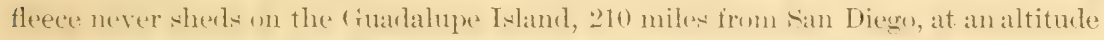
of only from 2,000 to 4,000 feet. I have grown mohair there 2 feet long, of lovely texture. We had 80,000 wild goats roaming on the island without any attention,

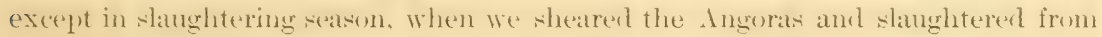
14,000 to 15,000 common goats for their hides and tallow. The goats all ran wild and took care of themselves. We were not at one dollar expense on them.

In considering Angorar culture it is of more importance to study the climate with reference to moisture rather than trumprature. It should be remembered that the original home of the goat is bigh up in the mountains, where the air is not laden with moisture. Truder like conditions it thrives hest here. Lowlands that are wet or mashy are not at all suitahle. The etfect of sulh situations soon makes itself alplarent in a flock of goats. Foot rot is apt to give endless trouble, and the feet will nexd much attention in other resperets. Therefore lowlands with much moisture and high temperature are not recommended for goat culture. It is a historical fact that the first effort to transplant the Angoral goat outside of Asia was a failure on aceoment of these ronditions. This was in 15int. when a few indiriduals were taken to Holland, but they soon died, owing to the moist climate.

The effect of climate has a great deal to do with the character of mohair. On this point Mr. Tohn s. Irarris, of Oakley, Idaho, who is a gentleman of much experience, is quoted:

Mohair grown here in Idaho is very bright when scoured, and, owing to the elec-

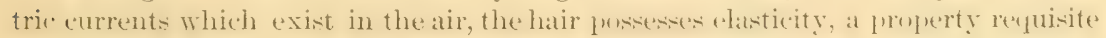
to mohair. Goats do not grow a long staple here, but owing to the cold it is very dense. Neither do they grow so heavy a fleece as in a milder climate, owing to the crynes of the air. Plenty of green, natural herhage the year roumd would procluce a heavier fleece and ultimately deteriorate its quality.

I high altitude is a locality always preferable in goat coulture. 'This is esperially true with Angoras. as the climate in high altituder seems to have a beneficial effect upon the mohair.

colonel Black. whose experience covers a period of thirty years. says that the Angoral gont will thrive in any part of our country and

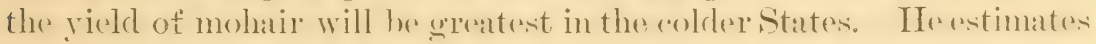
that the rield "an he increased fully 1 pound hy removing the gouts from Texas to any of the Northern States. 
CHARACTER OF SOIL.

Almost any kind of soil, except wet and marshy land, is suitable for these goats. Their preference is mountainous or rocky land, where they find it necessary to climb mountain sides and rocky clifts to browse. Such situations not only afford them satisfaction in (climbing and feeding, but the rocks serve to keep the feet trimmed. This is an important matter, for on soils devoid of stones or sand the feet must oftentimes be trimmed by hand.

One of the reasons for the freedom of goats from most diseases is that they require pure water, and in no place is better water found than in the springs and rivulets of hilly or rocky localities. Goats also require much exercise, much more than sheep, and such situations satisfy this inclination.

However, it must not be understood that rocks and hills are essential, although they provide for the goat an ideal situation. As stated above, almost any kind of soil is suitable except wet and marshy land. Goats arr not partial to water in any form-in the soil or in the form of rain, snow. or sleet-and they drink a very small amount. Keep the goats dry overhead and under foot.

LAND AVAILABLE FOR GOAT CULTURE,

The habits of goats, as set forth in the earlier paragraphs of this paper, sleggest at ones to the informed person that there are in the Lnited states millions of acres of land suitable for goat culture which are now serving no economic purpose whatever. Much of this would answer for sherp raising, but muth more of it is suitable for goats only.

In the northwestern States there are hundreds of thousands of acres of forest land which, on account of the forest corering, is uselesis, but when goats clear it of all underbrush and put it in proper condition for cultivation, as they are doing there at this time, the land becomes more valuable for other kinds of farm crops. In other places there is much hrush land which it is desirable to have goats transform into good pasture land, and there are also vast acres of momntainous and hilly districts which are ideal locations for Angoral gouts, hut which could be of no importance as pasture or as tillable land.

Cippt. Almont Banes, in the article entitled * Képing goats for profit," makes some estimates of the amomnt of mimproved land in the comtry, hasing his alculations upon the reports of the Eleventh Census. In finds that the total amount of mimproved land in the United States is $265,000,000$ areres. In Maine there are $6,0000,000$ acres in farms, of which $3.1000,000$ and improved; in Georgia are $25,000,000$ in firms, of which $9.500,000$ are improved. He concludes:

There is, however, in the L'nited states a large, (ontinuons area, enubracing ovel one-third of the states and Territuries, which invites particular attention in connextion with this subject. It includes the sunth Atlantic and Sonth Central divisions 


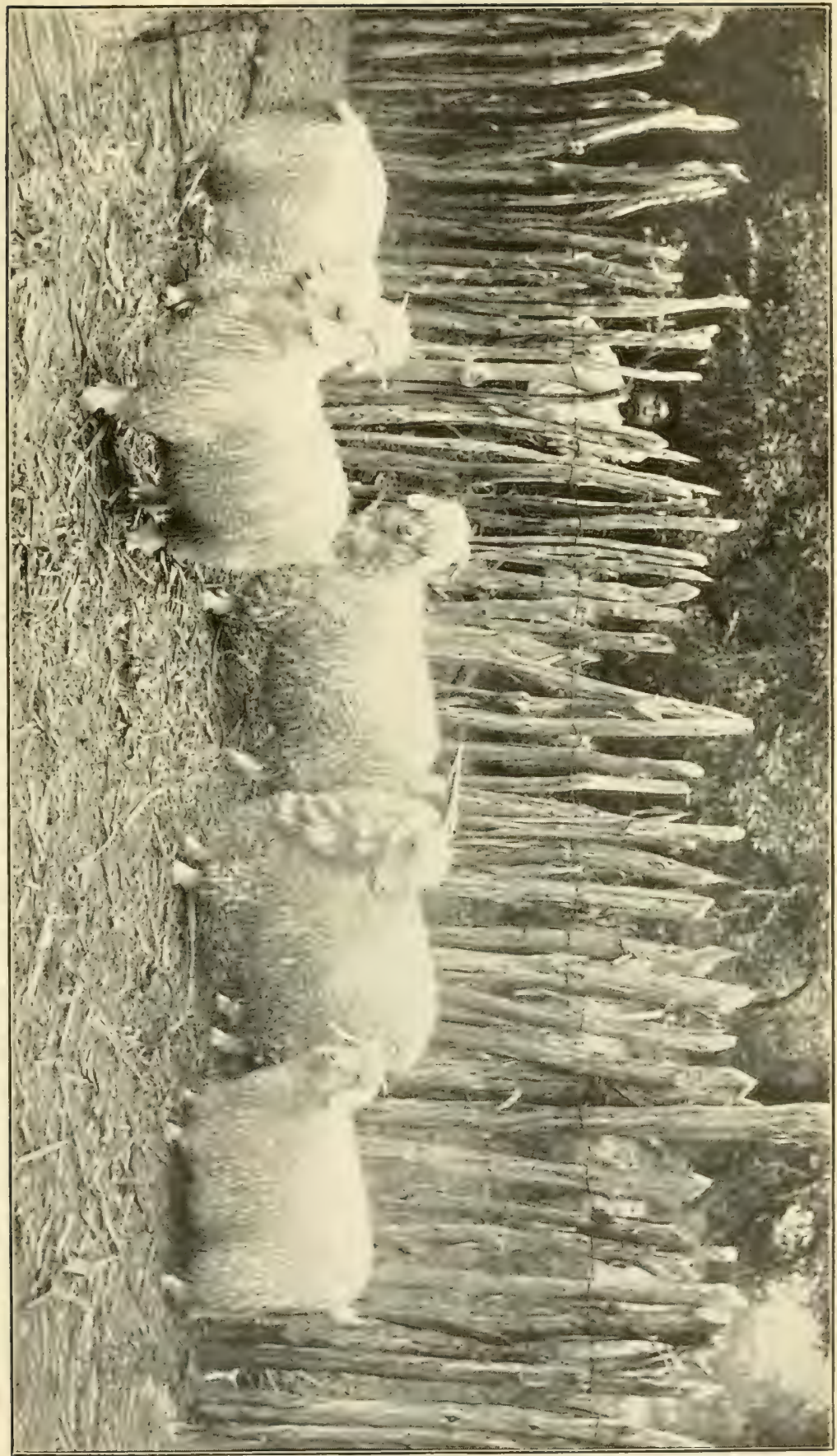






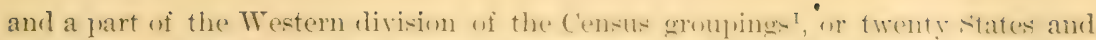

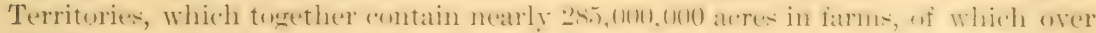

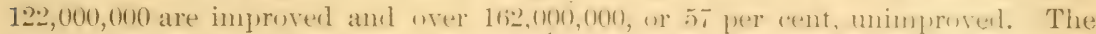
average size of famns and the average anmunts of unimpored land atre greater in this area than elsewhere, and the climatic conditions are more uniform.

It is safe to say that it will be many years before the matter of arailable land for goat culture beeomes a prohlem. It is sufficient at this time to know that there is an alumdance of suitable land ererywhere in the country.

Mr. W. Hammond Tonke, in the Agricultural Iournal of Cape of Good Hope for" May, 1899, says:

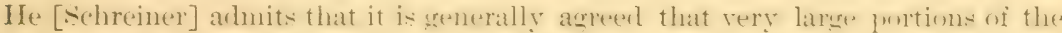

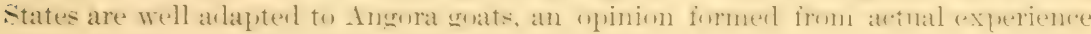
over a number of years. This being so, it is difficult to understand how it is that the industry has prouresent on sowly, reeing that the hair is valuahle, the shins in

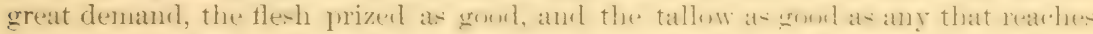

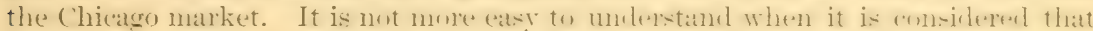
large portions of the country are suitable for goats and not suitable for sheep.

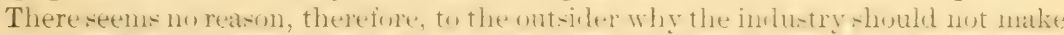
almost as rapid progress in the States as it has in South Africa.

THE CARE OF ANGORA GOATS.

The preceding pages have no doubt given the impresion that Angora goats are rery hardy, and. indered, it is true. (2x)ecrially if their foundation is upon crosies with the common eront: hut this should not be taken by the areless or shiftless man as a lierene to sulject his goats to all manner of discomfort with the experetation that the results will be fully as satisfactory as if rational attention were given them. That these animals can withstand extreme colds. such as that of the islands of Alaskat. or extreme heat. such at that of (ruadalupe Island. is strong evidence of their fortitude and of the ir adatptathility to a wide range of temperature undere propere catre. The same fortitude is

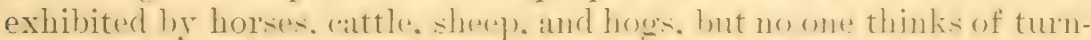
ing these dome-ticated animals out upon their own bersures. ats wild

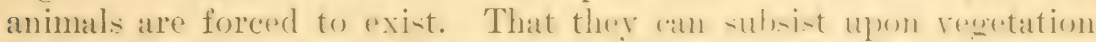

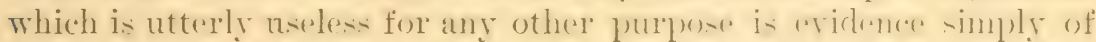

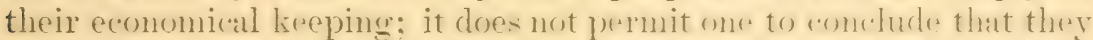
never need any othere lind of foed at times. In at word. it is intender

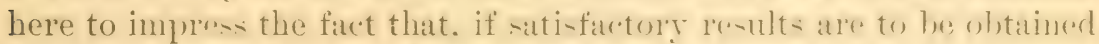
in groat raising. the animals munt resesive the same rational treatment that is received by other live stock when hest realuts are sought. 'The goat is a hardy animal in the fullest sen-e of the word, but this a bat acteristic only enaliles him to respond the more quickly and satistactorily to careful treatment.

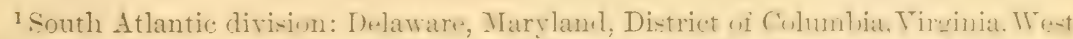

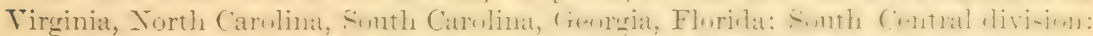

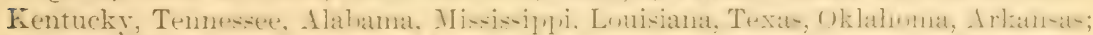

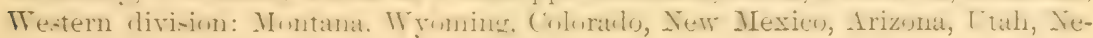
vada, Idaho, Washington, Oregon, California.
} 
HERIING AND FENCING.

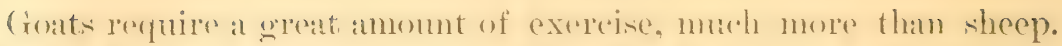

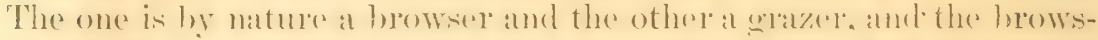

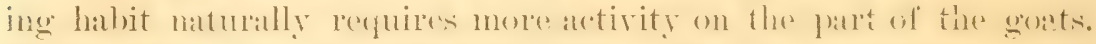
'They are semsitire to restraint and rlo bettere if mot hereled. hut of

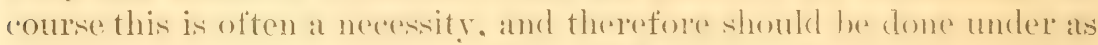

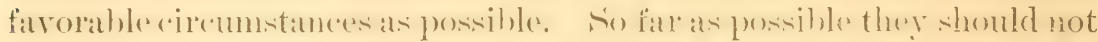
heallowed to foel their lestraint. If eomstant attrublance is nevessidy, the herder should he of quiet dispesition. The sext best thing to the

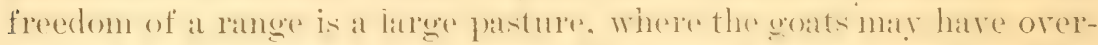
sight, but not constant attembance. Fuch pastures are considered the

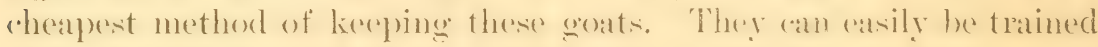
to come home hy fording a little and salting lexulaty at home.

The femeinge for patstures is a mattre which arty concerms one who

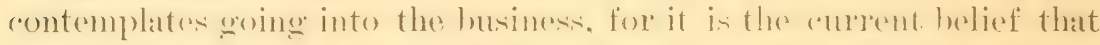
goats will climh onto an! shed of ordinaly herght or jump any fence that will stop other animals. While they will climb anything that is

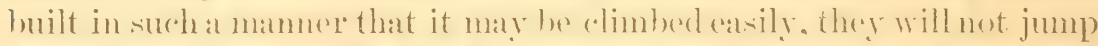
any ordinary fonce. Ther will, howerer, creep through if there is an

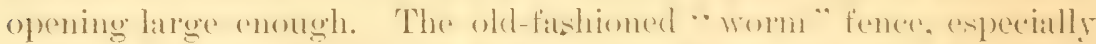

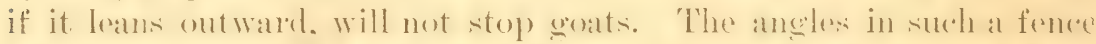
are an incentive and a delight to them. Indered, there are many hoger that will go orer a fence of this kind.

In huildime a goat forme there ane other matteris to be taken into aceount than simply that the goats shall he kept in: the animals themsolves (experially the pounge omes) must be ploterted from dogs and wolres from the onteide. In the sonthwest it is mule more important

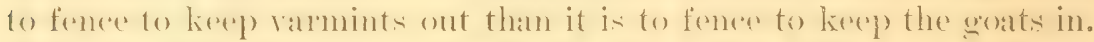
so the demble ohjoret must he kept in view in huilding a gont fence.

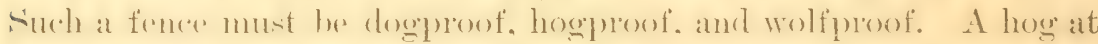
liherety which has onee had the taste of ehichem, or lamb, or kid is a greater muisane than any wolf or dow, and slunld le dispatched as being an enemy to other young live stock as well as kids.

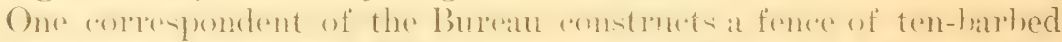

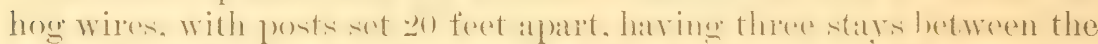
posts. The lowest wire is only 1 inch form the gromet; the next fout

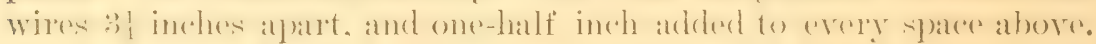
It is necessary that all the wires should be kept very tight. 'Ihis "orrespondent adek the interesting note that many wolves are killed by screw worms in wounds received while attempting to crawl thromsh rath a fence. I good femer may he made of woren wire 3 feed high, drawn on the inside of the prosts, and a closely barbed

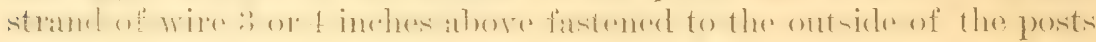
to prevent animals from jumping in. A straght lail fence, if the railis arr lail alose enough, ats well as an ordinary board fence, wili turn goats. 


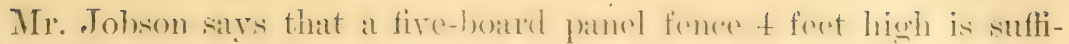

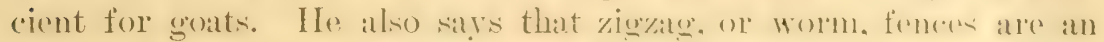
incentive for the woats to elimh, and that they will walk along the top) of such fences as easily as on the ground.

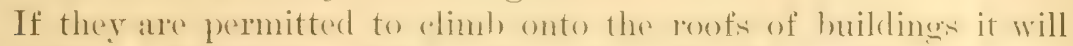
not be long before they will have them enmpletely rumed.

\section{SHELTER AND PENS.}

A shelter is necessary during wet spells, and mole esperablly if the

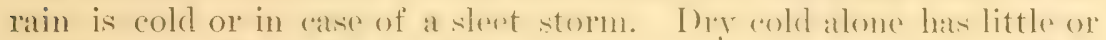

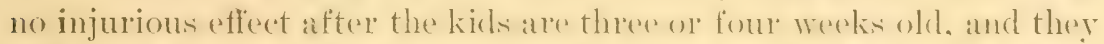
will eren frolie in the snow when the meremry is at zeres, and sleep) with apparent romfort in an open shed. With their dense corering there is no reasom why this should not he tran: hut this sime dense eovering. when sonked with cold watere or driven full of slext. is at deadly menace. (roats will not geot wet if they have an opportunity

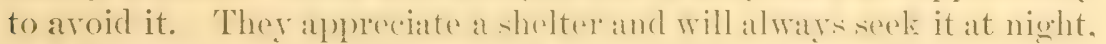
and during the day in the erent of stornss. 'Ther ale said to he excellent barometers, being able to foretell stormy weathere and alway contrive to place themselves under sheiter hesore the advance of a storm, if posiblele. Mr. I)ichl saly they will lun miles to aroid an undesirable rain.

Croats should not be left on the lanere or in pastume over night. The latter is practiced to a comsiderable "xtent, hut experience has shown that they are safer in closer confinement during the nighttime.

The pens in whinh the gats are kept at night should, ahove ali things, be in such a foration that they an be hapt dry be drainage. Other live stock should he exchuded, as they would only help to trample the erround into mud. 'They should hatre a dry place to stand and slecp). for they ale aljet to contratet rhemmatism in the kneses. There

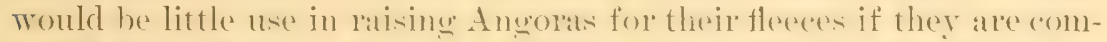
pelled to wade themele mud and filth, or he contined under these con-

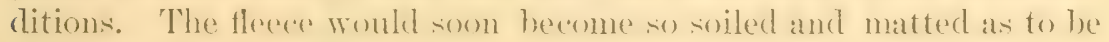
a "burden unto death."

The sheds provided for their shelter must be of a size to give an

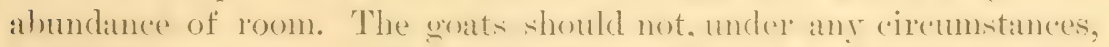

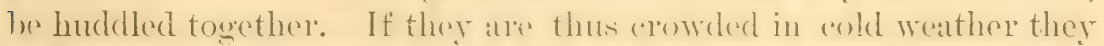
will pile 11 ). With the result that some of the younger ones will die from sufforation. One writer states that he has known as high as 30 heing killed in this manner in one night. Mr. Osear Tom. of Angera, Ores.e describes a shelter that proves sitisfactory in the following language:

The sheds should have eave troughs, and be boarded down to within 3 or 4 feet of the ground. There should be a ditch around the shed to prevent any water from

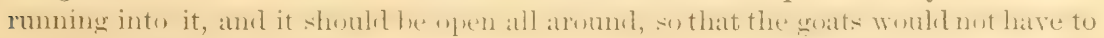
wait for other's ahearl of them to wn in: a fer wross ones could not block the way and 
keep other goats in or ont, and the rain would not blew in, hut the gonts would have plenty of fresh air. There should be a good fence around the shed at a distance of at least 50 yards, to keep cattle and horses from trampling up the gromel and working it into mud. Have the fence high enough for the goats to go under, but never allow hogs to run into the goat shed, for goats are easily frightened after dark.

In some parts of the country the strong winds will blow rain under a shed such as Mr. Tom deseriber. In such cases. the side from which these storms ustally come might he boarded to the ground. A better plan, in the opinion of some, is to have a few solicl movable panels of fence to plare around the openings of the shed on such oceasions. This plan is convenient, too, as the panels maty he taken away in fair weather, thus permitting a free circulation of air from all sides.

Shelter from the sun's rays should he provided for summer time. Although goats are able to withstand intense heat, they do not thrive well when subjected to it. For this purpose sheds more open than that deseribed above are preferred. for the reason that the air wili have freere circulation. Better yot than a shed against the sun's rays are large trees. In this ase there is no obstruction whaterer to the air.

FEEI)ING.

The principal rason why goats will be raised instead of sheep in some places is beramse they are practically inexpensive so far als feeding is concerned. This phase of the subject is quite fully disenssed moler the had of " Browsing and pasturage" (p). $2(6)$. They eat the leares in summer and the solt twigs in winter. and if there is an abmedane of either they will not require anything else to sustain life; hut this eondition exists only in certain localities, and other means must be adopted whewhere. They are fond of straw and fodder of any lind. Plate XI shows where a leerd in Iowat hats alecess to a straw stack.

Notwithstanding the ahility of goats to subsist upon coarse fodder' in the winter seatson, the impresion must not be held that they will thrive well upon it in the allsenese of howse. They will extract from these fockders all the nomrishnent olstainahle. which is not very great, but mist reedire some supplementary feed. Any kind of grain will answer this purpose. l'robably the best feed is ants, and if it is sheaf

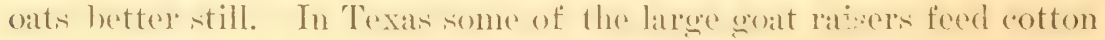
seed by seattering it upon the snow so that goats will hatre to exereise somewhit in picking it up) besides, the time (onsumed in pieking up) the seed thus scattered insures better mastication.

In fereding grain alre must be taken not to make the supply too liberal, unless the object is to fatten for slaughter. Croats easily beeome lazy on a plentiful supply of grain and will decline to go out to feed upon the brush. This is an important point. as their hardinesis to a lairge extent is attributed to their feeding upon browse and to the resulting exercise. 
As to the coarse feed for winter use, straw is eaten with relish; corn fodder is better and more nomishing" clorer and alfallat haty are exeellent. Indeed, very little grain will be resuired where either clover or alfalfa hay is provided. Mr. Hoerle says:

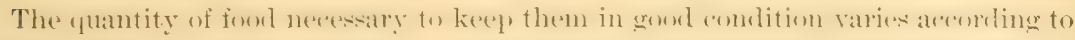
the climate, but one-fourth pound of corn or its equivalent in other grain and $1 \frac{1}{4}$ pounds of hay at a ration is about a fair average. With abundant winter pasture this ration once a day (in the evening) is sufficient; if the pasture is scant, they ought to have it both morning and evening, and on wet, cold days, when they are kept in the sheds all day, feert them three times or make their rations conresponst-

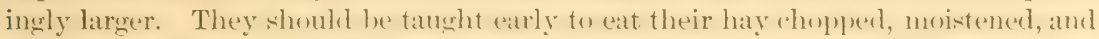
sprinkled with bran, oil meal, we corn meal, which, if it digests casice if given in that way, will save about 20 per cent of the feed. They should also be taught to eat ensilage where practicable.

Sugar-beet pulp) has been fort with success. The goats must be tamght to eat it, hut after once leaming they seem not to be able to get enough.

In feeding either hay of gratin absolute cleanliness must rule, as goats will not eat soiled food. There is no animal more particular about his food than the goat. He has no inclination for mud or filth in which to stand or walk, much less haring to pick his food out of it. Bryan Hook, author of Mileh Groats and Their Manawement, ${ }^{1}$ says:

The goat is of all animals the mont fastidions in the matter of the cleanliness of its

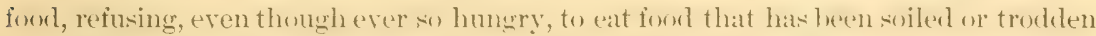

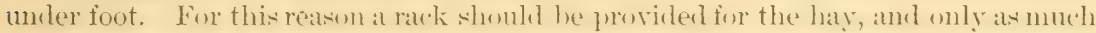
given at each meal as the animal will consmme, for that which has heen tramplest under fout will ever after be rejectenl, erent though carefully collexted and replated in the rack.

When the production of mohair is reduced to a fine art, the puestion of feed will receire the most careful consideration, because of its influence upon the fiber.

The replies recoived hy the Bureau to the yuestion "Do you feed in winter". If so, what is the character of feed!" are intresting in many particulars. It will be observed that in the fouthwest the treatment of goats in wintel is not rely different fon that reserved by them in the summer. Below ane given quotations fom some of the letter's received, credit being given to States only:

IVinters being mild, do not feed.-Arizona.

I have to feed here. They like alfalfa best. In southern New Mexico they never need any feed, and are good mutton the year round.-New Mexico.

We do not feed, there being plenty of evergreen brush.-New Mexico.

Feed only during severe storms, perhaps an average of three days in the winter, and then any kind of good hay will suffice--Texas.

Feed some poor old goats on cotton seed and hay.-Texas.

Winters are mild, and the goats live on evergreen brush (four kinds).-Texas.

${ }^{1}$ Vinton \& Co., Limited. London, 1896. 
Feed only when the ground is covered with snow and sleet. I like shelled corn best. Feed in troughs or swattered on the snow. - Terus.

Yes; in stormy winters we feer hay so placed that they can run to it in the shed, for they must have sheiter.-Oregon.

Native hay.-Oregon.

Very little; a few oats, and straw.-Oregon.

We manage to cut grubs in winter, but give them some straw; will eat most any kind of straw or hay,-Oregon.

I feed out in the prairie, along with the sheep; feed wild hay and lucern (alfalfa).Idatho.

Hay, oat hay, and corn from shock, unhusked; some roots, and more or less bram.-Iowee.

Sheaf oais, fodder, straw, and hay in spring.-Iowe.

They rum on the rumge all winter.-Teras.

Have never had occasion to feed, except during a snowstorm, when we cut down branches of live oak.-Texas.

Do not feed, except the bucks at breeding time; give them wheat hay and barley.Texes.

In Nevada we feed our kids some alfalfa hay, at night, for two or three months.Neracla.

I find shelled oats best for weakly ones; usually cut brush for the main herd during winter months.-Oregon.

We find clover hay and wheat and oats ent in the dough. We preter that to anything else- Oregon.

Stock fodder and clover hay. They will do well on the same feed as sheep.Missouri.

Not much grain, a little corn fodder, and wheat straw.-Kansas.

Shredded com fodder, wheat straw, and a little corn in bad weather.-Kunsas.

SALTING.

Goats refuire more salt than shesepe owing to the more astringent

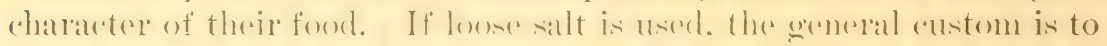

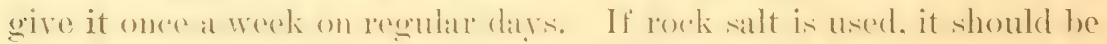
placed where the animals an ant to it at any time. Rock salt is pref-

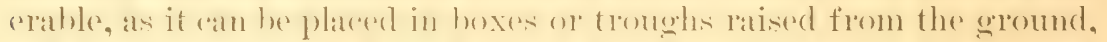

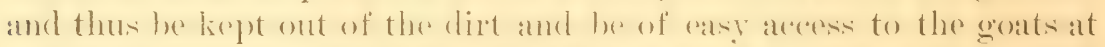
any time: and. tore, there is mo waste and no damger that the animal will eat too much of it.

MARKING.

The question of marking is always proper. Soromal deriees are in

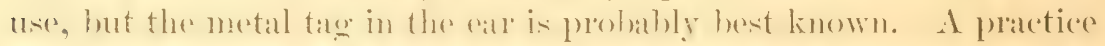
which appeare to wive satistatetion is to tatton the numbers into the ear. using indelible ink. It is fomm that the metal is sometimes pulled out by brush. 
KIDIDING ANI) TIIL KIISS.

The kidding time is the mest important in the life of the cents. For two or there days after the kids atre dropped they are exeredingly delieate, and there will be no future sureess unless good "atre is griven at the time. They "an not "rough it "at this periosl, hut will die from very little exposime or negrlece. They are more delieate for a

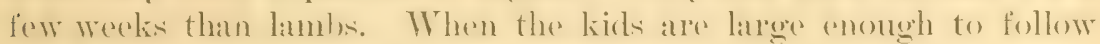
the flock they hare constitutions stronger than lambs of like atge and are able to care for themselves very well.

The proper time for bick to arrior is in the spring. about the time when leaves start on the trese and husher. At that time there is milkproducing food for the dre and the weather is alser warme rnough to faror the lids. The exact time maty be gererned, of course, by the servier of the bueks and will he earlier in lowalities where the seatsons are earliers. If kidding comes in cold weather, there will be greater difliculty in saringe the kids. Warm stabling must also be prorided. and the does will resuire extrat feeding in order that they maty supply milk for the kids.

A few days before a kid is due the doe should be serpatated from the flock. Some bienders would put her in a pen alcone, while others would put as many as 20 in one pen. If the facilities are at hand, a mall pen for each doe is bettre, for the reasons that the doe will soomer "own" the kid and there will he less dangere of injury than if among a number. A doe knows her kid by the semse of smell, espe(dially when it is romig. This chatrateristic is al) stromg that some moreders assert that if two kids of different mother's are rubbed together. the does will often refuse to own them. Whorerer "ares for the doe at kidding time will find it an important part of his work to see that the does own therio lids. This difficulty in any ate will disalpear in a fer daty. and it whit then only be necessary to arrange for the does to get to the kids whenever they desire.

If kids are dropped on the lange or in the pasture, they must he carrixd home and special are given to sees that the doesw are made to own them, for many times they will resinese. A lamb rill follow its mother rery soom after it is dropued, but a dee will hide her kid as hest she can in bushere or behind as stone or log. and leare it there while she goest atray to foed: and on her return she rapects to find it where she left it.

The Mexican method of handling the kid is langely practiced in

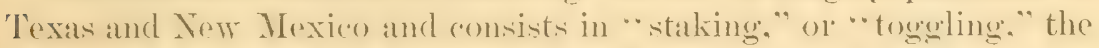
kid. When the kid is dreplexed, tirke it to a protected plater (shed or barn), seeing to it that the dere followis, and "stake it out "or "toggre" it with a string ahout 14 inches long. Tie this string to one lege. (dhanging occolsionally to other lexpe to aroid lamenest. This string shoukd have a swivel in it to prerent twisting. and the kids should be 
"alofully watched so long as they are so tied, which will be from seven to ten days.

The does should remain with the kids until they leave them of their own aceord to go out for feed. The lids may then be allowed to rum loose in a pen togethere until they are large enough to go out with the flock. which is when they are trom four to six wereks old, or when they are able to jump a board from 12 to go inches high placed across the gate. 'The height of this board restrains the kids that are too small to follow the flock and at the same time enables the does to go and (onne ats they pleater. W. G. Hughes \& Co., of Hasting's. Tex., have a device for separating the does from the kids which is better than the board. It is a hridge, eithere end of which drops to the desired height. 'This device enathles the does to go out and in without injuring the udder, which is apt to oceur where they have to jump a hoard. A picture of this bridge in use is shown in fig. of of Plate XII.

The following is from "California dngoras," published by C. P. Bailey \& Sons Company:

There are in use two methods of handling kids at kidding time, namely, the corral method and the staking method. Each of these has points which render it most valuable under certain conditions and in certain localities.

\section{The corral method.}

This method may be used with any number of goats. With various modifications 'mol alatations which hest sut the size of the flock, the elinatic conditions, the facilities for feeding, etc, it may be used by the beginner with success. We have practiced this method in Nevada for more than twenty-five years. If the herd is a large one, say 1,000 head, three men are required to handle the goats at kidding time. The

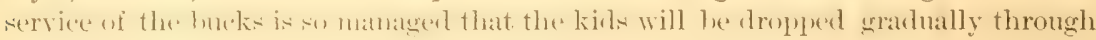
several weeks. At the height of the season we expect from 75 to 100 kids a day. The season lasts about thirty or forty days. Fortunately, most of the kids aie dropped in the daytime.

We have four or five small corrals, fenced with 36-inch woven wire and large enough to hold 50 does and their kids. The doe should be allowed plenty of room, because if too close to her neighbor she may adopt the other doe's kid. Besides

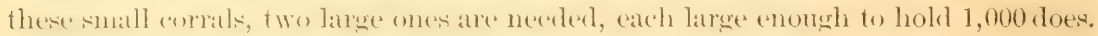
Along the fence of one of these corrals are a dozen small pens just large enough to hold a doe and kid. At the gate of this large corral a ump board is placed. This jump board is intended to keep back those kids which are not large and strong enough to jump over it. A 2-inch board about 18 inches high will answer the purpose. Another device sometimes used is a platform open at the end, so that the kids

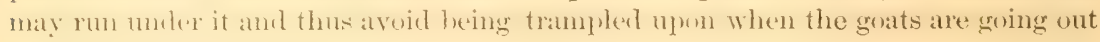
over the platform.

The small corrals may be made of panel fence and located in a meadow where some feert is afforterl. The deres should always have some kind of feed at kidding time.

In the morning the flock is arefully examined, and all does which show signs of kidrling during the day should he separatert and placed in one of the small corrals. The large flock is now turned out, and one of the men is sent with them with instructions to take the herd at once as far as he intemels wo go for feed that day, and then 


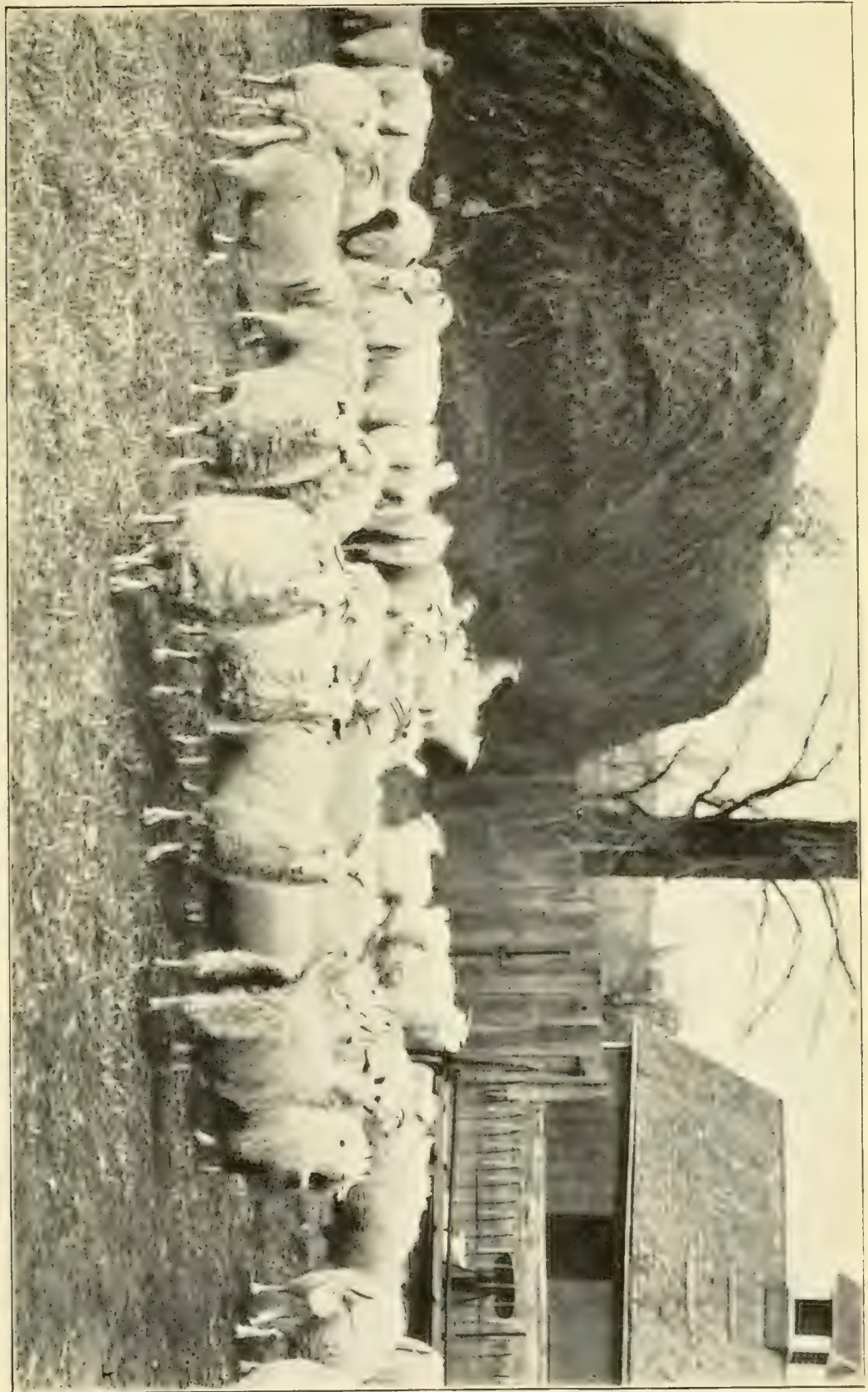




to let them feed over a limited area and gradually work their way home. A few does will drop their kids on the range, and the herder should carefully note the number and their location. IIe should ree that the herd does nost feed around one of these does, as she is apt to leave her kid and join the band, thus neresitating much extra work in finding the kid and in giving it to its mother. Farly in the afternoon the band is placed in one of the large corrals. Now the herder and another man go out with a wagon or on foot and carry the kisls home, gently driving the mothers. The kids should not be handled or rubled anainst one another more than is necessary, as the doe knows her kid by the scent. These does and kids are placed in the small corral which contains the doxs held back in the morning with the expectation that they would kid during the day. We mow have one day's kidding in one of the small corrals. The does and kids should be watched to see that they are properly arranged. Do not bother them more than is aholutely necessary. Do not be in a hurry to make a doe own a kid. Do not drive the goats around one of the small pens.

The does should remain with their kids in the corral for a day or two at least, or until the kids are properly mothered. Any does which have not. kidderl should be taken out. The next morning any kids which may have been born during the night are put in another small corral with their mothers, as well as the does which are expecterl to kid during the day. The procenture of the previons day is repeated. In about three days, if one has limited quarters, the first day's mothers amd kids may be put in the second large corral; that is, the one with the jump loard at the gate. Now this "wet" band is placed in charge of one of the men and sent out to feed. The gate is opened, the mothers passing out over the jump boarl, and the kids remain in the corral. The herler must not range his goats near the does that are kidding upon the range, and he should be cautioned to come in later than the "dry" band, so as to aroid any possibility of their mixing. When his hand arrives at the corral the gate is opened, and each mother hunts for her kid. Some of the kids may not find their mothers, and if atter a day or two there are a few umnourished kids and some does with overdistended urlders they should lee placed together in the small pens along the side of the corral. The doe will own the kid in a day or two, whether she is its mother or mot. The kids should not he allower to become too weak before this is done. If one does mot have enough small pens, a doe may be held while two or three kids suckle her', and thus tide them over until some of the small pens are vacant.

The next day the second day's kidding is arderl to the wet band. The wet band thus gradually grows, while the dry band decreases. During the day two men will be employed at herding the dry and wet bands, respectively, and the third man will be kept busy inspecting the kirk, feeling the does in confinement, ete. If the weather is stormy some of the kids will have to he shelteresl. The arlvisability of having the kids dropped grartually through a perion of thirty or forty days will readily be seen. If help is inexperienced they may loe gradually trained, or if the weather is stormy there will be time to get all things arranged properly.

The kids should not be allowed to go with their mothers until they are about 6 or 8 weeks old. If they go hefore this, they will probably become tired very soon and go to sleep. When they awake the band will have gone, and they are liable to be lost. During the day, while the mothers are feerling, the kids would eat a little grass if they could be herded near the corral.

As stated before, there may be many modifications of this method which will suggest themselves, but the above is a general outline of a method commonly in use.

\section{The staking method.}

This method is largely employerl, even with large flocks, in New Mexico, but is possibly best suited to small flocks. It is without doubt the hest method for certain surroundings. About the vame ammont of help will he requires as with the corral $11786-\mathrm{No} .27-01-5$ 
method. There should be a good supply of stakes similar to tent stakes. There - hould alio be a supuly of swivel blocks which are about 4 inches long and having a hole bored near each end. A piece of rope about 6 inches long is fastened to the stake, and the of here coul is passerl through one of the holes in the swivel block and a knot tied in the end. Another piece of rope of equal length is likewise knotted and passed through the other hole of the swivel block, the loose end being tied to the kid's leg. Any swivel will taks the place of this primitive method. The herder or owner can how hime lf buring the winter monthis by making stakes and swivels and by cutting and attaching the ropes.

When a kid is born it is taken to a convenient place to stake and the mother is gently eraxed to follow. The stake is securely driven into the ground, and the kid fastened to it by the hind leg. The mother is left with the kid, in order that she may know where to find it upon returning from feerling. The kid should be staked where he can get plenty of sunshine, shade, and shelter. A small bush, a post, or a box will answer the purpose armirably. If there are twins, they must be so staked that they can surekle at the same time. The rope should be changerl from one hind lesp to the other oreasionally, to prevent merpual derelopment. Sometimes a rigorous kid gets thoroughly tangled and requires help.

The kid may thus he left staked until he is old (nough to.go with the flock, which is after six or eight weeks, or he may be put in a corral after a few days, as is done in the corral method.

There are many sucesstul breeders who use this method entirely. (One may expect to get good results if he follows either the corral or staking method carefully.

There is rery small losis among kids cared for as set forth above. Many of the hreeders on a large seale report the pereentage of increase as 100. This does not mean that erery kid lives, but that so few die that the losis is oflsest he the number of twins that are deopped.

The most practicable fencing to be used at kidding time is made of portathle pancls. By the use of these panels a pen may be made large or small and he moved from one place to another without difficulty and with very little work.

Wianim!. - Kids should not be weaned until they are $4 \frac{1}{2}$ months old unless they are very strong; but they should not remain with their mothers after they are 5 months old. This especially applies to the buck kids, as they will often breed at 6 months of age or even younger.

fistartimn.-The buck kids not reserved for breeding purposes shonld he castrated when ahout two weeks old. The earlier it is done, the hetter will be the meat and the mohair. It is pointed out in prerions pages that the mohair from wethers ranks with that from the does, and the flesh is superior to that of the does and inferior only in small degree to that of the kids. A cool day should always be selected for the operation of castration and careful attention given for a few days.

(J)inims of comespondents. - The quotations given below are a symposium of the opinions of most of the leading breeders of Angora goats in the United States on the matter of kidding:

There are several methorls of handling goats during kilding. The one employed here is the Mexiean plan. When the kit is troplext take it hy the hind legs, so that the doe will follow, to where you want to stake him. Stake with rope about 12 
inches long, with wooden swivel in center. Leave them staked until after they are marked and castrated and well owner by the mother. Sometintes kids are herded with their mothers and sometimes hy themselves until they learn to be herded. If not handled properly and the kids are allowed to mix together, the does loses the scent of her kirl, and young does will often divewn them.-F. (). Lomdrum, Laymum, Tex.

This is the most eritieal periorl in the handling of gonats. The kids are grenerally collected daily, as soon aty dropped amd alble to stand and suckle the mother, and are confined in a corral for several week, much of the time tied to a stake driven inte the ground. It is not safe to let them run with the flock until they are a month to six weeks of age, as they are liable to drop ont of the flock and be lost.-Col. Tr. L. Black, Fort McKavett, Tex.

The kidding season is the time when the work and care comes. The kids are more

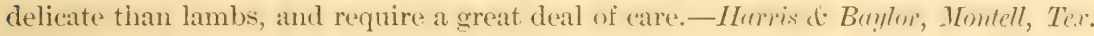

The easiest way to get through kidling time is to put all the does that are soon to bring kirls in a separate small pasture where they "an he lookerl np casily. In caso of harl weather they should be bronght into their shed everyerening before sundown; but if the weather is dry and not ton cold they (:in be left ont, and all the does will likely own their kirls. Of course, the kids will mot follow their mother as lambs do, but will lie down in a thicket or muler a bush, a weed, a log, or a rock, and remain there till the mother comes bak to it, even if it should have to wait till it starved to death; but after a kid is a few day, old it is ahle to follow its mother, although it is best to keep the kids at home. Kids need not suck oftener than twice a day. - II.T. Fuchs, Tiger Mills, Tex.

I stake the kid in a barn for two weeks. The mother gupsont in the daytime to feed and is put with the kid at night. After two weeks the kill is turnerd love and kept in a pen until 2 months old, when it is allowerl to go out with the flock.-IIenry Fink, Leon Springs, Tex.

We keep the nannie and kid to themselves so far as possible for a day or so, and do not allow more than 20 nannies and kids in the same jen until the kids are over a week old, nor more than 50 namnies and kids in the same pen until 2 weeks old. Kiòs are kejt in the je'n day and night until a month old, and are the'n allowerl to run outside the pen during the day to eat a little; the feed may be furnished them in the form of cut banches if there are nu bushes near the fen. They should also have access to water after 4 weeks old. When 6 weeks old they can go out with the flock for a few hours in the aftemoon, the flock being brought in at mislday for this purpose. After eight weeks they (an go regularly all day with the flock. We use a bridge for the purpose of "cutting back" such kids as should not go out with the flock.-W. G. Hughes \& Co., Hastings, Tex.

Protection from rain; confinement in a corral or small pasture until the kirls are 6 weeks old. We allow the does to jump over a 21-inch boath to gret ford and return as they please. We separate all does every morning that will drop kids within two or three days and keep them in a pasture by themselves.-Contilin Brothers, Nourille, Cal.

I put nannies that are soon to kid in an open pasture (not bushy). As the kids comc, gather them into al corral with a sherl or barn in it, taking the mothers with them. Keep the kids in the corral until they can jump over a 16 -inch board, turning their mothers in and ont evening and noming. At alwont 2 weeses of age they are usually fit to run with their mothers.-George A. Houck, Eugene, Oreg.

I aim to have a field of fall grain or reserver pasture to turn does in a few days before kidding commences, and turn the does in another pasture as fast as they drop their kirls. Ki (eep the kids mp about two weeks, then let them go with their mothers.Oscar Tom, Angora, Oreg. 
Put the goats in a small pasture near a shed. If stormy, take the kid and doe to the shed at once. Every night put all the kids and does in the shed. Put bars up 20 inches high, and when the kid (an jump over, let it go. Without a shed in this State you conkl mot raise two out of ten kids; there is too much cold rain in kidding time-March and April.-U. S. Grant, Dallas, Oreg.

Put the namies by themselves and then look after them once or twice a day to see that the kids are able to get up and suckle. Don't bother them, if they are all right and are in a sheltered place, until three or four days, and then change them to suit your convenience.-W. W. Smith, Eola, Oreg.

Take all the namnies out from the other goats as soon as they kid, and put them by themselves. I have about 100 small pens in which I put the namnies. Put the young nannies and old ones in different pens. Here they remain for four or five days and they are then turned into a larger pen, but not more than 50 should be put together.G. M. Scott, Malta, Idaho.

Comfortable shelter and close watch to see that the kids get milk promptly. Put the doe and kid away from flock for a few days.-J. Murray Hoag, Muquoketer, Toura.

We have a man on the spot all the time to help the goats in kidding, if necessary, and also to see that the kids begin to suck. - Richurdson IBrothers, Dubuque, Iowa.

Have good warm shelter, and under no circumstances allow cold rain to fall on the kids till after they are 2 weeks old. The shed should be open to the south, so that the sum 'an shine in on the kids. 'Turn the does ont of the sherl once a day, and leave the kids in the shed for the first two weeks. By that time the kids wil! be old enough to follow the doe.-W. T. McIntire, Kansas City, Mo.

I always keep the kids in a corral until they are old enough to follow the doe, which is when they are abont thirty days old. In taking the kids to the corral care should be taken to get nothing on them that will change the scent, for does are very sensitive. If two kirls from different does are rubbed together, the does will often refuse to own either of them. All kids should be castrated before two weeks old, as there is less danger and they do not get so sore.-H. I. Kimball, Ifaxwell City, N. ITex.

I cut out the heary ewer from the rest of the herd, and hold them in a clowe herd, and eatch the kidls and bring them with their mothers to the corral, where each kid isstaked separately with a tuggrle, or swivel, being careful to see that the mother knows where the kid is. After this I let the new mother goats exme and go at will, only notieing them enough to sese that they come to their kids rexularly. The kids should be watched closely in oriler that they may not get tangled up and hurt. When they are alout 2 weeks old they are turned lowe in a corral and a board is put at the gate orer which the mothers jump in going to and from their kids. When the kids are 3 months old they may be allowed to go with the herd.-Josephus R. Barnette, Globe, Ariz.

THE BUILDING UP ANI) MANAGEMENT OF A FLOCK OF ANGORA GOATS.

THE BEST FLOCK.

It is assumed that whoever goes into the business of raising Angora goats does so for the production of mohair, rather than meat or skins,

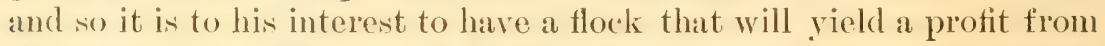
the beginning. The best flock for this purpose is one composed of thoroughbred.. ${ }^{1}$ Such a flock will yield good mohair from the first.

${ }^{1}$ The term purtheds j,s not used here, as there is strong oljection to it hy many of the best breelers, on the ground that there are no purelorede, as texplained elsewhere. As the term thromelimeds will exactly suit the purposes of this chapter it is preferred, leaving the question of purebreds to be discussed by others. 
Those who enter upon the businesis of goat raising, howerer, must make their operations conform to their eapital, the same as in any other business. They will find that desirahle does will cost from sio to 812 each, and bucks all the way from $\$ 20$ to $\$ 100$ each; so that a large herd of this kind, although preferable, will cost a small fortune, and is beyond consideration by most people who will engage in the industry.

BUILDING UP A FLOCK FROM SMALL BEGINNING.

Another plan that may he pursued by one who has limited capital, but time and the patience to wait, is to begin with a few first-class animals and build up a flock from these. The result will be satisfactory, and the only drawback is the length of time required. After all, this may be the wisest plan for most beginners to pursue, as experience, so necessary always to suceess, will be gained as the flock increases.

BUILDING UP A FLOCK BY CROSSING UPON THE COMMON GOAT.

It is noted in the historical part of this paper that the Turks many years ago began the practice of crossing Angora bucks upon Kurd does. They probably had in mind the twofold purpose of producing thereby a hardier goat than the pure Angoras and of increasing the number of goats in order to supply the increased demand of Europe for mohair. Crossing the Angora bucks upon the common goats of the United States has been practiced since their introduction, and the results have been very satisfactory in many respects. Many of the large flocks of Texas and New Mexico have had Mexiean does for their foundation. Building up a good mohair-producing flock upon this plan requires five or six years. The adrantages are that the does with which the heginning is made are cheap, costing from \$1.50 to $\$ 2.50$ per head. During the first and second crosses there are many twin kids, thus increasing the herd in that proportion-a condition not existing, except to a small extent, among either the purebred or thoroughbred Angoras; the size and hardihood of the progeny are increased and the liability to disease decreased.

Care should be exercised in starting a flock by this method to select only such common does as are entirely white; any other color, however slight, is objectionahle. If otherwise, the results might be satisfactory, but the probabilities would be the contrary. In handling the crosses the breeder often finds that atarism becomes apparent when it is most objectionable. For instance, the progeny for two generations of a doe having black spots might appear all that is desirable, while the third generation would produce the latent color.

In starting with a bunch of common goats that you want to use for raising a graded flock of shearing goats you should use only as pure white goats as you can get, and you should allow no colored goats in the flock. Fou should also dispose of all those that have long, coarse hair on the thigh and on the fore legs, below the shoulder. 
In fart, the erommon genats that you want to start your flock with should be niee and smosth built, with small hearl and short, smooth hair and mall horns. From muleys you can raise heavy shearers, but their mohair is not quite so fine.-H.T. Fuchs, Tiger Mills, Tex.

If bred for the purpose of quick profragation, and with very fine, robust goats of both sexes to begin with, in six years five or six crosses can easily be obtained if nutrimental adrantages are favorable; and if really first-elass bucks, having all the most valuable points this side of perfection, can be procured, and inbreeding carefully avoided, even our common short-haired and smooth-coated goat will, after the fourth cross-say, beginning with the thirty-second-show inprovement, which in a large flock on general inspection would defy detection by anyone but an expert judge of Angora goats.-G. A. Hoerle, Ridgewood, N.J.

It is always quite necessary that the common does should be of the short-haired variety. Long-haired ones will give trouble in persisting to throw out long hairs among the mohair.

The buck used upon these does should be the best one can afford. The better the buck, the better the result. 'There will be many twins among the kids from this first cross, and if proper care is exercised at kidding time it will not be difficult to increase the flock as much as 100 per cent. 'The higher the cross, the fewer twins will be dropped. As the fleece upon the first cross is not worth more than the effort to clip it, the males among then should be castrated when about 2 weeks old and disposed of for meat as soon as old enough. The females among them, being half-blood Angoras, are kept for service with another thoroughbred buck. The result of this second cross is threequarter blood Angoras. The mohair from them has a marketable value, but is very limited in quantity and usually mostly kemp. It is best to deal with this cross in the same mamner as with the first cross. If this method of procedure is followed up to the fifth or sixth cross a flock will result that will produce most excellent mohair.

It has no doubt occurred to the reader that we now have four or five different grades of does, begimning with the common breed. 'Therefore after a thoroughhred Hock has once been produced in this manner, each year brings forth another one from the same sources, and this condition continues as long as the breeding life of the does continues.

PROPER AGE FOR BREEDING.

Froats of both sexes will sometimes breed when they are 5 months old, and often at 6 months, but from the fact that they are at this age but a month or two from weaning time and are not nearly full grown, it is obrious that they should not be permitted to breed. They reach maturity when about 16 or is months old, and they ought not to breed before this time. If hred earlier the kids will not he so strong or so well dereloped. They are in their prime when from 2 to 6 years old, but with proper feeding in winter they have been known to breed regularly until 15 years old. The arerage life of goats, however, is about 12 years. There should be no tendency to keep does until they 
are rery old unless they bring kids of exeeptional merit, for it must be remembered that their mohair gets coarser, and ronsecfuently less valuable, as they grow older.

.The accompanying illustration (Fig. 1) shows how the age of goats may be determined until they are four year's old. After that, in the alsence of definite information, the age is a mere matter of goness. based upon the general appearance of the animal. The new teeth are longer and larger.

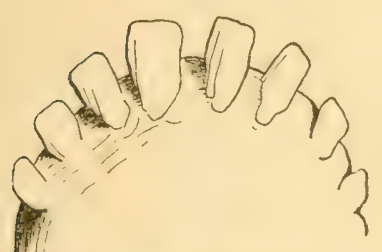

FIRSt YEAR

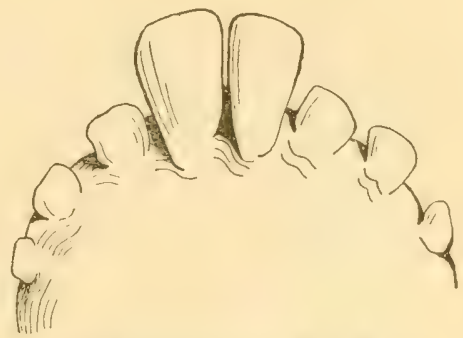

SECOND YEAR

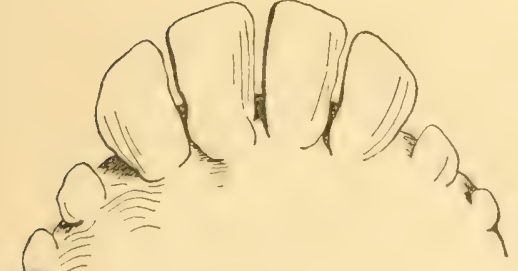

THIRD YEAR

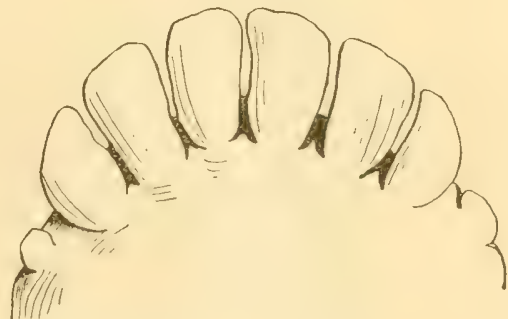

FOURTH YEAR

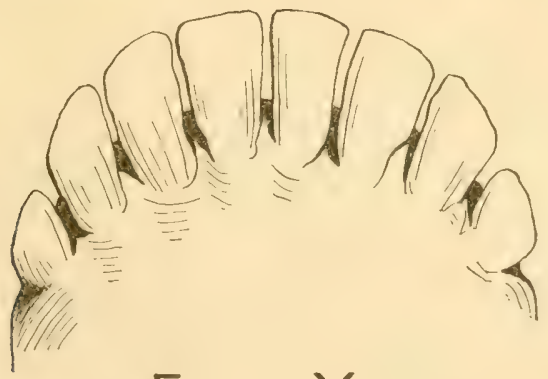

\section{FIFTH YEAR}

Fig. 1.-The age of goats shown by the teeth. [Copied from Bryan Hook's "Milch goats and their management."]

IN-AND-IN BREEDING.

In-and-in breeding means the breeding of related individuals. The term is indefinite, and with some refers to at (ose relationship) and with others any degree of relationship. The correspondence of the Burrau 
with goat raisers shows that the term with them means generally the brceding of individuals of close relationship.

It is safe to say that there is an overwhelming sentiment against the practice. This will be apparent after one has read the replies which are published herewith to the question, "What is your opinion of in-and-in breeding?" It is quite generally agreed, however, that this practice will give a fleece of finest fiber, having a beatiful luster and little oil, but the weight will not be so great. Those who favor the practice contend that the quality more than offsets the quantity. The animals resulting from this practice are not so large and strong as those which are not related. The fact must not be orerlooked, however, that Mr. John S. Harris, of Oakley, Idaho, has followed in-and-in breeding continuously and with evident suceess, and, too, they are kept in a climate where the temperature in winter is sometimes far below zero. But Mr. Harris is a gentleman who understands the art of breeding; if all goat raisers knew so well the principles of breeding as he does there might not be so many to condemm the practice. However, they have learned much by experience, and it can not be contended that they are wrong in advising generally against the practice. Col. Richard Peters, the most successful hreeder of his day, said that halt-blood does can with best results be bred to their own sires, provided the sires have proved themselves to be good breeders.

If inbreeding of closely related animals is meant, it should not be resorted to with live stock of any kind excent when individuals which show very desirable points are at the same time of very strong constitution and of good size. But, then, I would never hesitate to hreed even parents to children. Strict observance of this rule I consider doulhy necesary with Ingoras, which are naturally tender and delicate, and it should he risked nnly when chances are rery strong that the gain of fleece or shape will fully empensate for the inevitable lose of sime and constitution. I believe that in a very few yours that the value of the anmal product of meat (from her offerping) of a doe will surpass that of her mohair. Besides, the more constitution is gained, the more apt are we to return to the original prolificuess of the goat tribe, which has been entirely lont with Angoras in consequence of inl reeding. With the third free generation usually, hut always with the fourth, bad effects of mating relations would not be felt any more.-G. A. Hoerle, Ridgewood, N. J.

The opinion of our leating authorities, such as Profeswor Sanford and others, is that in-and-in loreching is the most succesful way, and many cases are citerl where this has been carried on for over thirty years. We have some breeders here who have been inbreding for the frat eight years, and the result, when the greatest of care is exercised, is that we have produced some very fine stock, as fine, I believe, as any that has been raised in this country. This in-and-in breeding is a very particular riece of work and should not be attempterl by anyone mless he intends to give it his undivided attention. I believe it is the most successful way to breed for a fine fiber. The greatest trouble seems to be in the size the animal, but if careful attention is paid to the work there is no excuse for losing size. We have demonstrated beyond all doult that in-and-in breeding produces a finer wool, a longer wool, and a better wool; so if one desires to breed for fine worl he will have to follow in-and-in breeding.-E. H. Jobson, Lake Valley, N. Mex. 


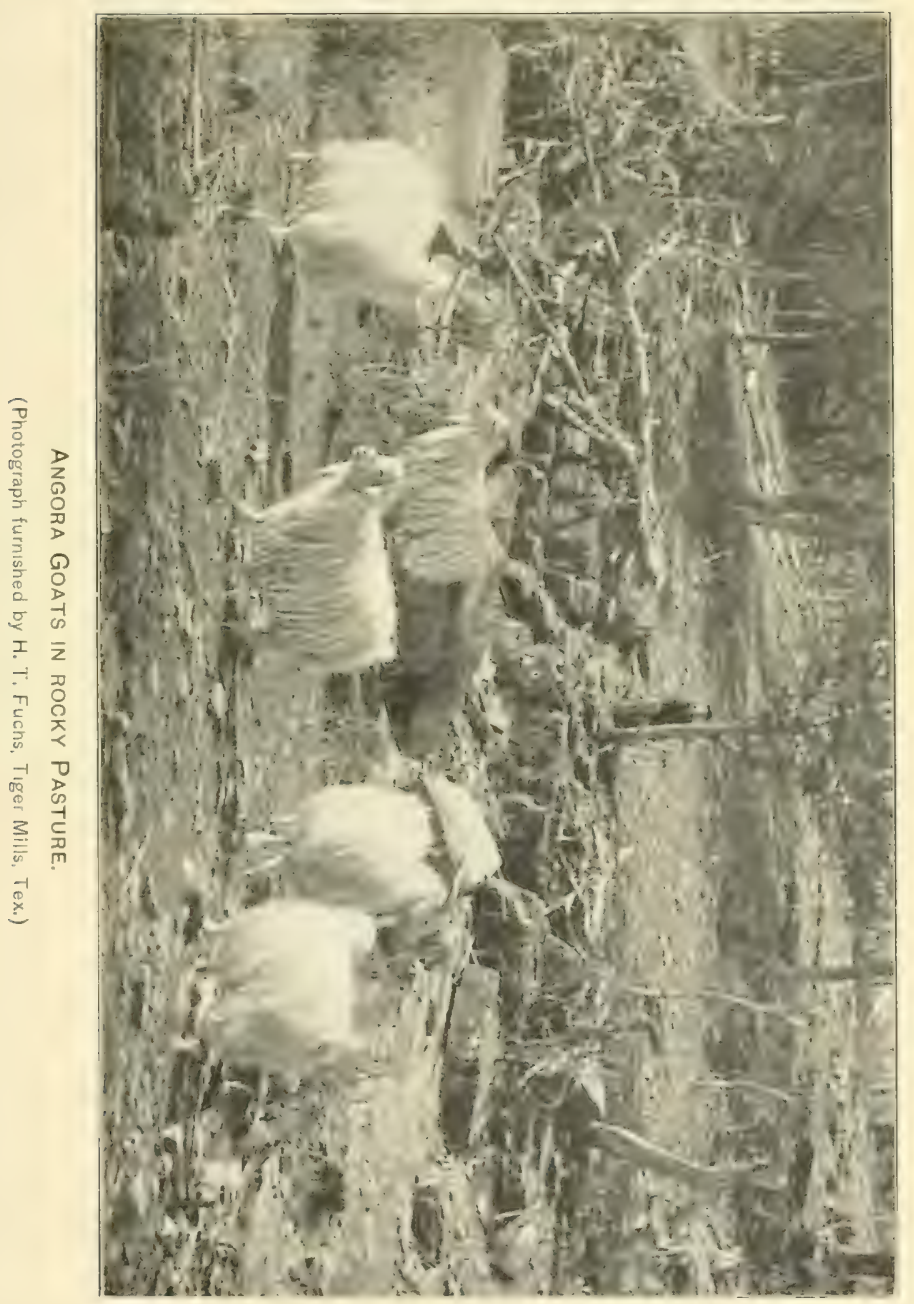





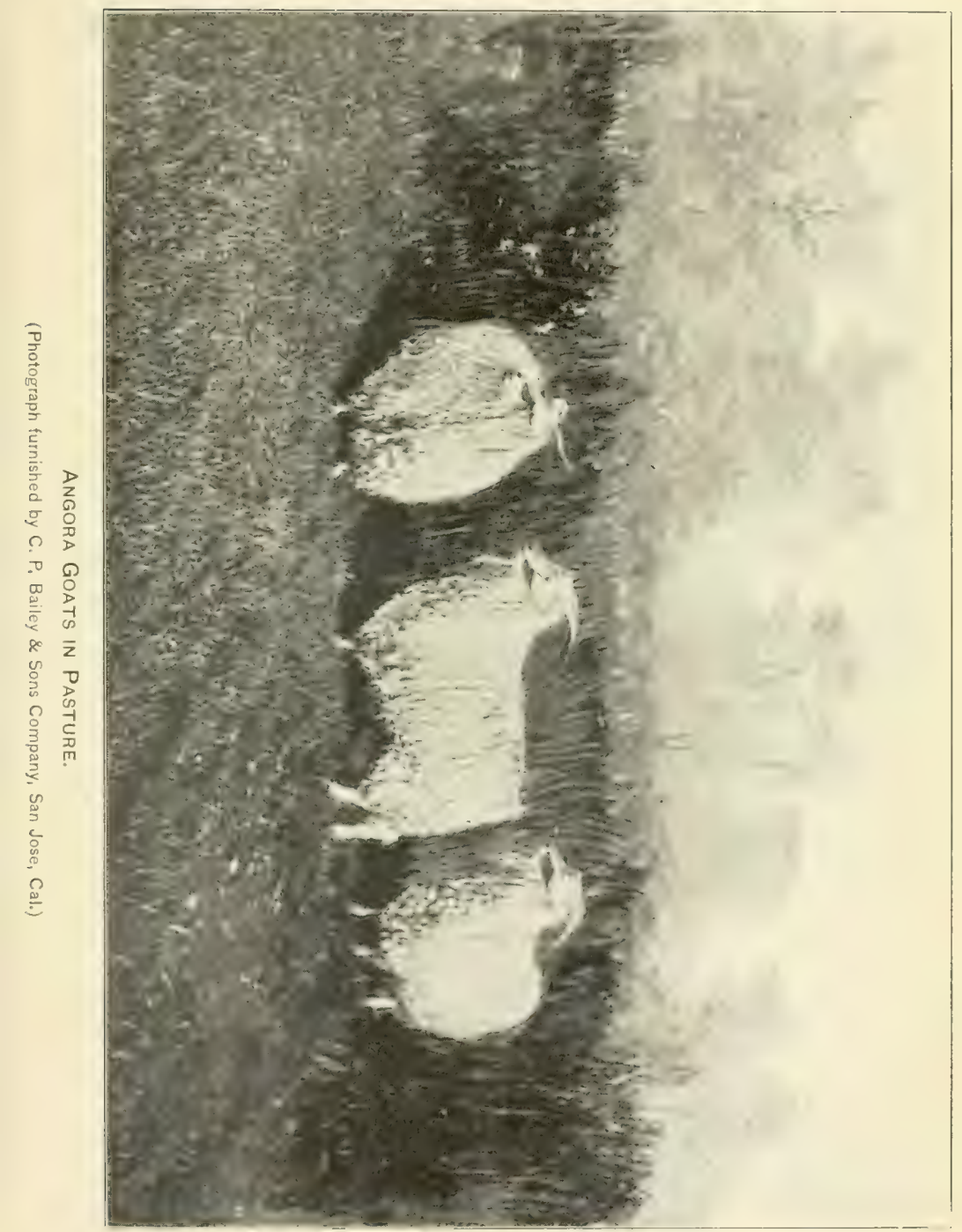



T think that to get a perfect. goat one should inhreesl to the finest luxk or ewe obtainable; but don't keep it up ton long, as the goat will be mall and weakly.Josephus R. Barnette, Globe, Ariz.

We think it should be avoided so far an pussible, as it reduces the size and general stamina of the goat.-IV. G. Hughes \& Co., Hastings, Tex.

It will ruin a flock of goats the same as any other animal. - li. It. Iothustom, Lumrence, Kans.

If done properly, closely watching defects, it is all right. - J. R. standley, I'latteville, Iowa.

Would not practice it if I could help it. We want goats with long, fine mohair, but at the same time we must look to the build of the guat.-(?. M. Beck, Bectrgrore, Iowa.

Am opposed to it on general principles. Would prefer it, however, to a moderate extent, to using inferior sires.-J. Murray Hoag, Maquoketa, Iowa.

I don't like inbreeding, as it weakens the goat. They don't have the ambition that fresh blood imparts to them.-G. M. Scott, Malta, Idaho.

They will be small and not strong, and harder to raise; will not shear so much, and more difficult to keep in flesh.- W. W. Smith, Eola, Oreg.

My stock are all inbred (600 does), hut they are very small and tender. Would not advise it. $-V$. Cladek, Larwood, Oreg.

Once will do, provided you have an extra buck. After that you weaken the constitution of your goat.-U.S. Grant, Dallas, Oreg.

It can be practiced to advantage in producing a fine fleece, but if indulged too much will weaken the constitution and the goat will be suall.-Abe Blucliburn, North Iamhill, Oreg.

I believe, by careful selection of bucks, they can be improved, but I prefer crosing with new blood when it is just as good.-Oscar Tom, Angora, Oreg.

It shatters the constitution without a relative gain in weight of fleece. Fine mohair and light fleeces are all right, but I don't practice inbreeding. It produces such a goat as the practical man does not want.-George A. Houck, Eugene, Oreg.

We do not approve of it on general principles, but have not experimented much along this line.-C. P. Bailey, San Jose, Cal.

Under certain circunstances inbreeding for points in thoroughbreds is necessary, but it will degenerate a grade herd very quickly.-Comtin Brothers, Nevrille, chal.

I do not like it and have never practiced it. I have seen it practicerl, and the goats lack constitution.-Henry Fink, Leon Springs, Tex.

It brings the mohair to the greatest fineness if properly managed, but it should not be kept up too long.-H. T. Fuchs, Tiger Mills, Tex.

It is beneficial in the matter of improving the fleece, but a decided injury to the constitution and size of the animal.-Col. W. L. Black, Fort IfcKavett, Tex.

I used one billy five years. He was the hest goat that I ever saw, shearing $10_{2}^{1}$ pounds of clean mohair annually.-G. B. Miller, Gervais, Oreg.

Inbreeding makes the fleece thinner and shorter and the constitution of the goat weaker.-F. O. Landrum, Laguna, Tex. 
MANAGEMENT OF THE BUCK.

Bucks usually come in heat alout the middle of July and continue so about six monthis; does, howerer, do not usually come in heat until the latter part of August or the 1st of September. As the period of gestation in goats is from 147 to 155 days (or about five months), care must be taken in mating the animals in order to have the kids dropped in proper season, which will vary somewhat with the locality. 'The kids should not come hefore the warm days of spring, or when regetation begins to put out rigorously. Therefore the buck should be put to service from November 1 to December 1 , so that the kids will come about the 1st of April or May. The only objection to earlier kidding is the extra care required to preserve the life of the kids, for they are exceedingly delicate for a few days, as has been stated before, and even a little cold at this season will probably prove fatal.

A buck, like any other domestic animal, should be in the best possible condition when put to service. He should be well fed with grain for a few weeks before this time, and the feeding should be kept up until a few weeks after his service is ended.

As to the number of does which a buck may serve, there is a great diversity of opinion. The greater number of goat raiser's, however, think forty or fifty is all that may be served with good results. Col. Richard Peters wrote that he had obtained the best results with two hundred breeding does by turning in with them ten selected bucks. His object wats to have the kids come as nearly at one time as possible, thus shortening the period of careful watehing. Referring to Colonel Peters's practice, Dr. J. R. Standley says he regards it a great success, and will adopt it in the future. He says, further: "I have tried the one-service system, also turning in hucks at night, removing them during the diy, and other plans, but decidedly prefer Colonel Peters's plan."

Where there are very large flocks it is not always desirable that the kids should all come at one time. If they are dropped at intervals for a month one attendant may thus be enabled to look after a large number, whereas if all come about the same time one attendant could not do the work, and assistants who may be stranger's to the flock would be necessary. (It is not well to have many strangers with these goats at any time, and rertainly not at kidding time.) Upon this point $\mathrm{Mr}$. G. A. Hoerle has written out a plan. given helow, which is quite generally followed where there are large flocks:

A great difference of of ninion exists as to how many ewes an Angora buck should be allowerl to rerve. This depends both upon the bucks and the condition they are in, as well as upon the length of the period during which you want the kisls to drop. In a mall herd, and where ample conveniences for kidding are furnished, so that goond care can be taken of all the kids at onee if necessary, one buck whould serve from thirty to fifty (as alweve said, according to the animal); but should the flock be large, and owing to the uncertainty of the clinate or the insufficient help or shelter 


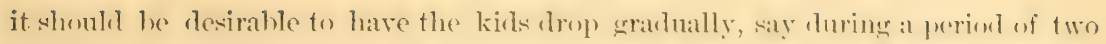

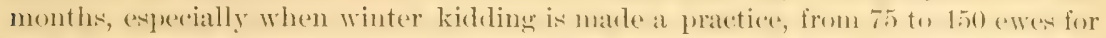
each buck is not $t(x)$ much-again, alecording to animal aurl time. Thery should not run with the entire 1 lock at once, but bexin with say one-third to one-fourth of it, according to circumstances. The next similar fraction should be put in the breeding flock from two to five days later, and so on until gradually the entire flock is with the bueks. In this way a full crop of kids would be insured and at the same time the bucks prevented from doing excessive service.

The handling of "riginals" (ridgels) should have a word here. If the one testicle which descends is removed, the riginal will not get kids, but he will bother the does. If the descended testicle is not removed, he will breed without difficulty. He should be killed as soon as practicable.

NUMBER OF KIDS.

Thoroughbred Angora goats do not often drop more than one kid at a time, while the common goats nearly always drop two. There are many twins with the first cross, but the number diminishes as the crosses become higher. It is stated that the purebred Angoras never dropped but one at a time, and that the presence of twins in a flock is evidence of a base origin of the goats. The latter statement is disputed by some, who beliere that the purebred Angora (having no trace whatever of base blood) will drop twins as regularly as the common goat.

SIZE OF FLOCKS.

All goat raisers agree that Angoras can not stand crowding together; and the higher the grade of the goats the more susceptible are they to injury from crowding. But to state just how many should be kept in a flock is difficult, as the number depends upon the character of their restraint. Where they have the range at day and large yards at night, the flocks may he very large, but where they have pastures and small pens at night the flock must not be large.

Writers upon the Angora industry have placed so much stress upon the point of overerowding that the Bureau sought for information upon the question "What should be the size of Angora flocks?" Each correspondent replied with his own experience, and the conclusion is reached from the replies that they may he handled in flocks about as sheep are handled, the number depending wholly upon the capacity of the range or pasture, as the number's reported for flocks are from 100 to 2,500 . However, the danger from crowding is not disputed by any of the correspondents, and many of them mention it specifically. This phase of the matter must be carefully considered in comnection with the question of housing and shelter. These must be ample to afford abundance of room and fresh air.

It is stated by some that goats rumning in small flocks shear more than the same number running in large flocks. 
DEHORNING.

Dehorning the goats has received very little consideration, and it is probable that Mr. Q. M. Beck, of Berropere, Iowa, is the only goat raiser who is now practicing it. Many other hreeder's report that they do not dehorn but helieve it practicalole, while a rery few express opposition to the practice. Mr. Beck writes as follows: "I dehorned forty-five head last fall $(18 S 9)$ and found it a success, as it stops a great deal of bunting, which is liable to cause abortion, saves shed room, saves broken legs, and will save many kids." These same reasons have brought the dehorning of eattle in quite general faror among feeders, and it is probable that as the Angora goat industry grows into a large industry the practice of relieving the goats of their uncivilized weapons of warfare will be generally adopted.

Mr. Beck dehorns in the fall after all flies are gone.

A different riew of the question of dehorning is taken by C. P. Bailey \& Sons (o., who dehorned yo head which were in a band by themselves. They bunted as much or more than before the horns were removed. "Goats always hutt each other', but we have never seen any ill effects resulting, except oceasionally a leg being broken from being aught hetween the homs. It deprives them of their only means of defense, and we consider it umecessary and objectionahle."

\section{SHEARING AND SIEDDING.}

SHEARING ONCE OR TWICE A YEAR.

In 'Texas. New Mexico, Arizona, and sometimes in California shearing is done twice a year-in the months of Iarch or April and in September or October. The reasons are that, owing to the warm climatr, the flece will often shed in the fall if not elipped. Mr. H.T. Fuchs, of 'Tiger Mills, Tex., says: "I find it quite necessary to shear twice a year, as they sufler too much from heat in the summer and atutumn and even during the warm days in winter if they are not sheared albout the middle of feptember, and in the springtime as soon as they begin to shed their long silky hair." There are instances in these localities where goats carry their fleece through the year, but all breeders, except in some parts of California, report the practice of shearing twice a year. In the other parts of the country shearing is dons hut once a year, and that in the months of March or April. The rule for shearing time does not depend so much upon the calendar as upon the condition of the flexer. It should not le delayed until the fiber begins to shed, as then the oil will begin to go back into the body of the animal, the mohair thus losing its life and luster.

As to the relative values of the semianmul and ammul fleeces, there does not seem to be much difference of opinion. The semiannual fiber is shorter and therefore less desirable for fabricating, and the price is not so high as for that of the ammual theece. It is generally agreed 
that the two shearings combined weigh a little more than the amnual shearing, but probably the increase does not arerage more than a quarter of a pound. However, some who have practiced it report that the gain is not equal to the cost of the second shearing, and that shearing twice is done from necessity rather than from the standpoint of profit.

USE OF CLIPPING MACHINES.

The use of clipping machines, although largely employed among large sheep raisers, has not yet come into general use among goat raisers. Those who have used them indorse them, and they will no IJubt soon come into general use. They are more rapid than hand work, and the results are more satisfactory. The cutting of the skin is easily aroided in reasonably careful hands, while it requires extreme eare with hand shears to prevent catting. Mr. H. I. Kimball, of New Mexico, says of the use of the machines: "I sheared them [the goats] myself faster than the best hand shearer I ever saw, and I got a better" price for my mohair." Another gentleman says: "I will say that the clipping machine for sheep will work well on goats in every respect. I have sheared ten goats in one hour and done up the fleeces."

Of course, the goat raiser will consider the relative cost of shearing with machines and by hand before he will purchase a machine. The decision will probably depend upon the number. The cost of hand shearing is about $t$ cents a head. In the Southwest there are Mexicans who follow the profession of shearing sheep and goats; these usually receive 2 cents a head with their board. Many of them will shear 85 or 90 a day, the arerage of all being about 60. Any man who can shear sheep can shear goats. If shearing is done by hand, a shortbladed shear should be used in order to aroid cutting the hair twice.

Another objection to hand shearing is that there is often double cutting of the hair. The result is a shortening of the fiber and an increased amount of noilage.

If the animals are well rared for during the year, their fleece will not require washing before clipping. One writer of experience satys that "the natural habits of the Angora goats are clean enough to enable spiming before washing, at least for some purposes." Any dirt that may adhere to the fleece should carefully be picked off after shearing.

CARE OF THE FLEECE AFTER SHEARING.

The operation of shearing should be done in a building free from straw and dirt, which might adhere to the fleece after it drops from the goat. It should then be rolled up, inside out, and packed in the sack without being tied in any way. This is the manner in which the mills desire to receire it. The practice of tying the flecce with almost any kind of twine that may he at hand ohtains very largely among goat raisers, but the wishes of the mill operators are already receiving 
proper attention. The reasons why the mill operator's do not desire fleeces tied are very forcibly stated by one of them (George B. Goodall), as follows:

I want to mention another evil which should be correcterl, and that is the use of twine or string aromind the fleeces. Tenetahle fibers will not take dyes used for animal fibers, and in cutting these strings by the sorters more or less of the regetable fibers get into the mohair and have to be arefully hurled out from the face of the finisher goom, which ards to the cost of each piece. A mohair fleece should he simply rolled up without twine of any descrintion. You never see it on Turkey or Cape mohair.

If mohair producers insist on the use of twine, the quality should he hard and smooth. so that no particle of it will adhere to the mohair when it is eut away.

As to assorting the fleeces with reference to the quality of the mohair, no common practice is followed by producer's. Some assort them at shearing time and pack in separate sacks, while others pack all sorts together. If the producer is a good judge of mohair, the former method will prove more satisfactory. When all are packed together indiscriminately, the poorer grades of fiber tend to reduce the average price of the whole lot. IIowever, many prefer to pack thus indiscriminately, learing the work and judgment of assorting to the commission merchant. Most of the mills purchase from the commission merchant because of his skill in assorting.

There are appended some opinions on this subject of Mr. Hoerle which are worthy of consideration:

Before folding up the fleces they whould be carefully asoorted, if this is possible, in the following way:

A. Combing hair, or all hair over $4 \frac{1}{2}$ inches in length:

1. The very finest, as fine as fine kid hair.

2. Next finest, or average run of good doe fleeces.

3. General run of fair doe and good wether fleeces.

4. Coarse fleeces.

B. Carding hair, or less than $4 \frac{1}{2}$ inches long:

1. Fineness of class 1 above.

2. Fineness of classes 2 and 3 .

3. Coarse fleeces.

At shearing time fleeces of similar quality and length shomld be packed together, and special care should be taken not to allow tag ends and hurrs to remain in the flecess. The latter should be carefully picked out before the shearing begins and the former pulled off before packing aml placed in a special hag, and marked sepatrately. It is much more profitable to have small lots of low-priced short ends and tags and to pull out with the burrs a few strands of the mohair than to have an entire clip depreciated by careless shearing and packing.

SHEDDING.

The question of shedding is provoking much discussion among goat raisers at this time. Some maintain that the goats shed regularly, while other's assert that the purebreds and best thoroughbreds do not 
shed at all. The correspondenere of the Bureat shows that practically all of the goats in this country shed their fleser, either ammually in the colder localities or semiammally in the wamer climates. The question submitted hy the Bureau was, " I)o thoroughhords shed if not sheared?" There were many positive aftimative replies received and several modified answers. Among the lattel are rasons why some goats do not shed. It will he of interest, and probably of some profit, to consider some of these replies in any effort toward reaching a conclusion regarding this question, and they are given herewith:

They will all shed in the spring, when warm weather begins, but the higher they are bred up the Ionger they will go without shexhling.-II. T. Fuchs, Tiger Mills, Ter.

Some will shed. I regard the nomsherhling Angora as a distinct type, and all the

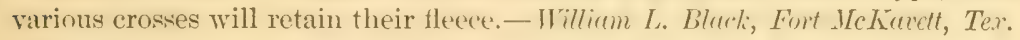

I have goats that never shed, hut they are feel for show purposes during winter. If ordinary care is given, they shed.-Abe Blackburn, North Yamhill, Oreg.

I have had goats that did not shed at 1 year old, but did at 2 . I think feeding conditions are responsible for such cases.-George A. Houck, Eugene, Oreg.

Goats of second cross sometimes do not shed. Depends on condition of goat.U. S. Grant, Dallas, Oreg.

Many thorotghbreds will sherl, and we have grartes that do not. Mueh depends upon the physical comblition of the goat. If it is in por flesh and fattens rapidly in spring, it is very apt to commence sherlding, just as many sheee do under similar conditions. - W. G. Hughes \& Co., Hastings, Tex.

Though most breeders in this comntry disagree with me in my nomberling views, I am supported by the Cape breeders. One of them, Mr. R. C. Holmes, is very decirled in his expressions. He says: "With regard to well-hred goats shedding their hair, I quite agree with you that they should not do so. In fact, among my goats it is an exceptional thing to see a goat sherl, and even the ewes at kidding tine do not shed. At this period some few may do so, but very few indeed, and a ram should never shed." This does not lack in clearness. Angoras will sometimes lose their hair from disease, a change of clinate, or a change of weather evern, or a suclden change from a continued iry food to green foorl, etc. This may appear at any time of the year, regardless of the reason, and has abolutely nothing to do with the yearly shedeling of low-bred goats. No yearly shediler should be classed at a thoroughbred."-G. A. Hoerle, Ridgeu'ood, N. J.

Under certain conditions they will sherl, but not if the goats are in goed health.— E. A. Hinkle, Roseburg, Oreg.

I have about fifty head of namnies that do not sherl, but most gorats sherl if not sheared.-G. M. Scott, Malta, Idaho.

\section{DISEASES AND OTHER ENEMIES.}

Goats are less subject to disease than sheep; but these specier are so closely allied that treatment in cases of disease is the same for hoth. Several accounts have been published in the agricultural press of goats in the Southwest being affected with stomach worms and with grub in the head, the same as sheep are affected in the same localities. There are occasionally outhreaks of disease in certain localities, but these are due to local causes, and generally have not been difticult to orercome. 
The treatment recommended for the screw worm is as follows: Add to any one of the carbolic sheep dips 10 per cent of chloroform. Apply this mixture, after thoroughly cleaning the wound, with a wad of cotton. The chloroform immediately destroys the larva and the carbolic dip prevents the further blowing of the wound.

The stomach worm (strongylus comtontus) is the same form as found in sheep, cattle, and deer. The treatment in all cases is the same as for sheep.

Goats have at least three kinds of scab parasites peculiar to their species, but apparently only two kinds of scab develop. Psoroptic scab of sheep does not develop disease upon them, though it can undoubtedly sustain life for a while.

Tapeworms of the genus Moniezia are found in goats. In the intestines are also found five round worms, namely, Strongylus filicollis,

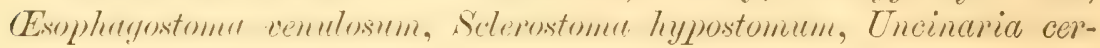
mea, and Trichocephalus affinis.

Verminous pneumonia of sheep also occurs in goats.

Tuberculosis is so rare in goats that every case is recorded, the number of such cases being less than a dozen. It may be said, therefore, that they are practically immune from this widespread and insidious disease.

Goats are apt to have foot rot, but a cure is easily effected by the use of sulphate of copper (blue vitriol). It is usually applied by driving the goats through a trough containing a solution of strong blue vitriol. The solution should be about an inch in depth. Oscar Tom, a breeder of much experience, says:

Butter of antimony applied with a stiff feather will cure it, or mix 1 ounce of sulphuric acid with 2 ounces of vinegar and apply as above. Go over the whole band. Generally one application cures if well done. ('hange the range at the same time if you can.

Angoras are frequently affected with lice, which cause a loss of mohair from the rubhing and scratching of the goat. The lice may be exterminated hy dipping. The common sheep dips are generally used for the purpose. It is a common practice to dip the goats once a year, and some advise dipping twice a year-in spring just after shearing and again in the fall.

One of the principal enemies of the Angoras is the wolf. The best guard against wolves is a good wire fence. Sometimes the wolves dig under the fence, and then it becomes necessary to trap them. This is practiced by Mr. H. T. Fuchs, who says:

Three steel traps are fastened to each other, hut to mothing else, and catch the wolves. If the trap is male fast the wolf will hreak loose, but the weight of three traps fastened together simply tires the wolf out, and it rarely drags them more than 200 or 300 yards.

In miny localities the wildeats are especially troublesome. Their prey is the kids. 


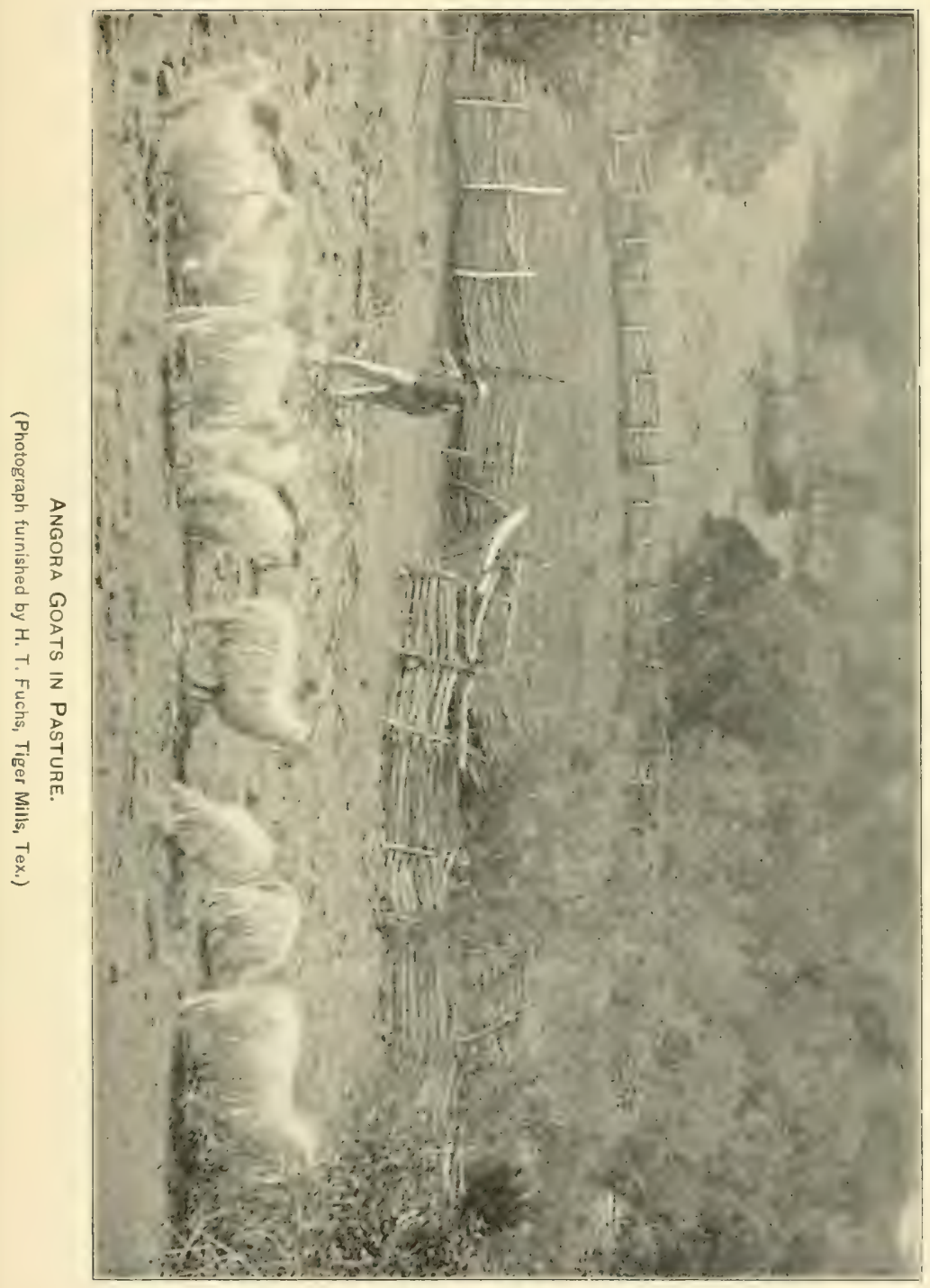





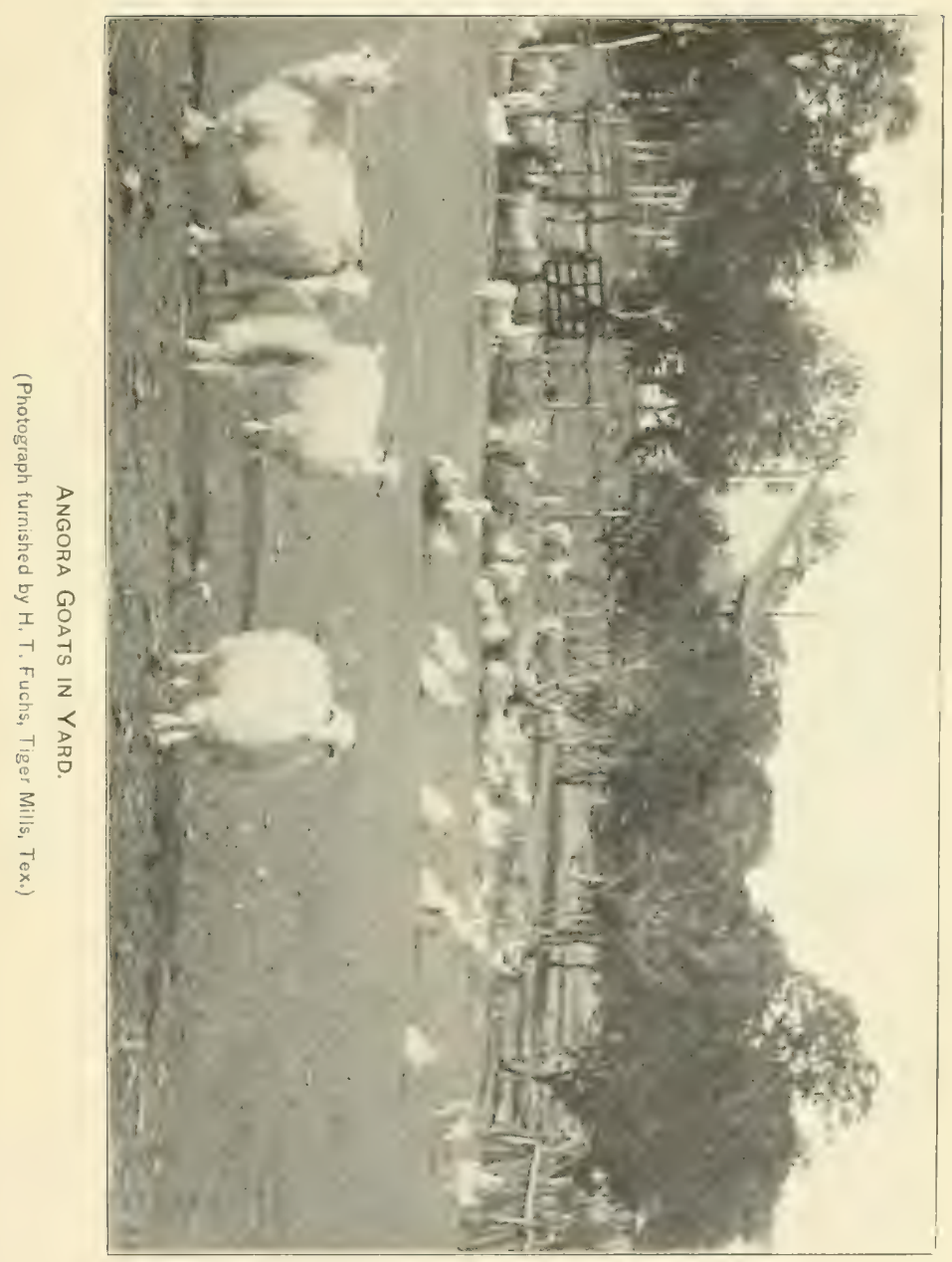





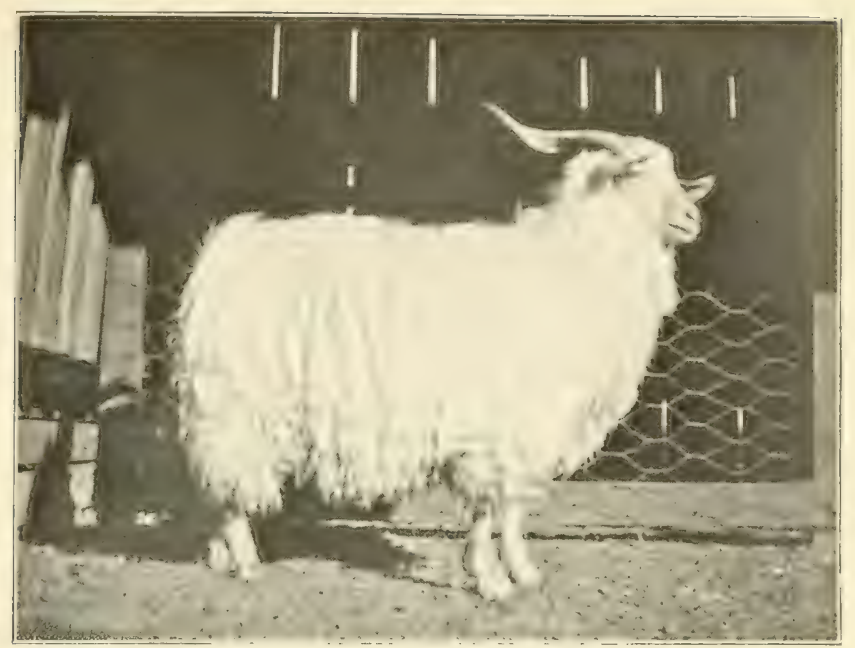

FIG. 1.-A YEARLING ANGORA GOAT.

Photograph furnished by W. G. Hughes \&\& $\mathrm{C}_{0}$.)

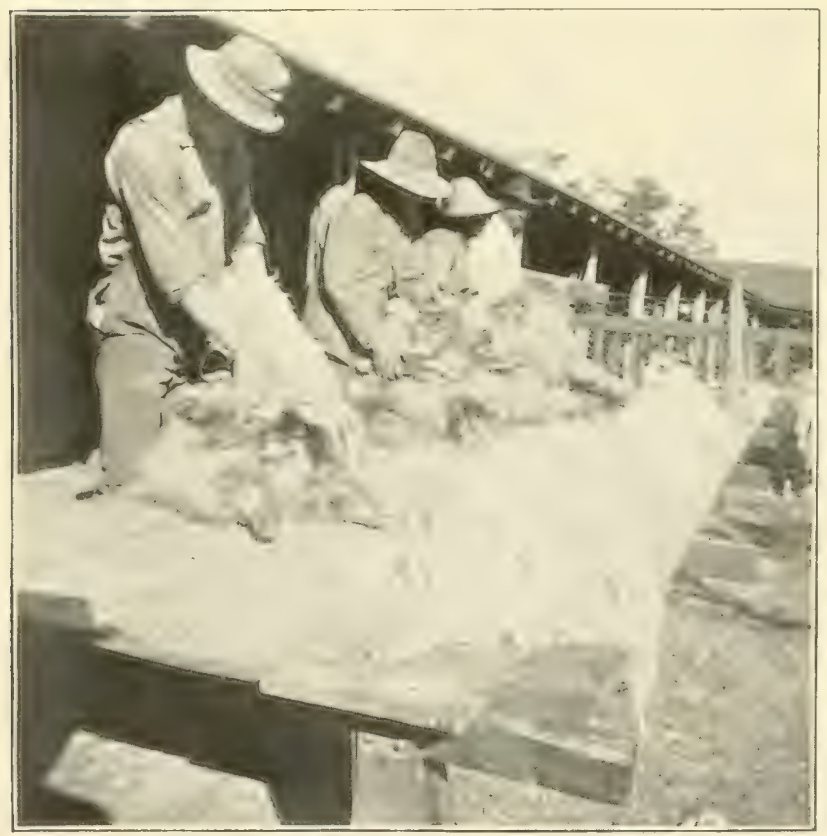

Fig. 2.-SHEARING ANGORA GOATS.

(Photograph furnished by W. G Hughes \& $C_{0}$.) 

The fact that many plants which are poisonous to sheep and eattle may be eaten with impunity hy goats is frequently referred to by writers for the press. It is true. howerer, that goats sometimes die from eating poisonous plants. especially in the mountainous districts of the Carolinas, as the Bureat is informed through correspondence. The so-called "ground iry" is specially referred to. It is helieved that goats will not eat poisonous plants to an injurious extent unless driven by hunger to do so.

\section{NUMBER OF ANGORA GOATS.}

IN THE UNITED STATES.

The census reports previous to the year 1900 have not given the number of goats in the United States; the Twelfth Census, however, will show the number of Angoras, as well as the number of common goats.

Col. William M. Black, of Fort McKarett, Tex. in 1898 estimated the total number (including all grades) to be 247,755 , located in States and Territories as follows:

\begin{tabular}{|c|c|c|}
\hline & & (2) \\
\hline alifornia.... & 59,000 & South Carolina ............... \\
\hline 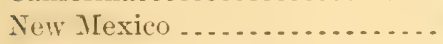 & 52,000 & North Carolina............... \\
\hline regon ${ }^{1} \ldots \ldots \ldots \ldots \ldots$ & 15,000 & Colorado................. \\
\hline evarla.... & 11,500 & Mississippi . . . . . . \\
\hline - & 8,1000 & Louisiana . . . . . . . . . . . . . \\
\hline ming ..................... & 7,000 & ecticut ................. \\
\hline 1а................... & 5,700 & na................. \\
\hline uri . & 5,200 & Ar \\
\hline (n. & 2,000 & Flc \\
\hline na.................. & 1,500 & (2.1. \\
\hline s $\ldots \ldots \ldots \ldots \ldots \ldots \ldots \ldots$ & 1,200 & Virginia $\ldots \ldots \ldots \ldots \ldots \ldots \ldots$ \\
\hline Territory.............. & 900 & Nebraska .................. \\
\hline ia. . . & 750 & Washington . . . . . . . . . . . . . \\
\hline$x y \ldots \ldots \ldots . .6$. & 500 & West Virginia..................... \\
\hline & 400 & \\
\hline - & 300 & \\
\hline
\end{tabular}

About a rear later Mr. William R. Parne, of New York, estimated the total number at $300,(0)($. If these estimates are anywhere nearly correct, the present number must he rery much greater, probably as many as 400,000 .

IN CAPE OF GOON HOPE.

MIr. WV. Hammond 'Tooke, in the Agrienttural Journal of the (ape of Good IIope for May 2.5, 1s!9!, gives the number of Angora goati for $1893-1898$ as follows:

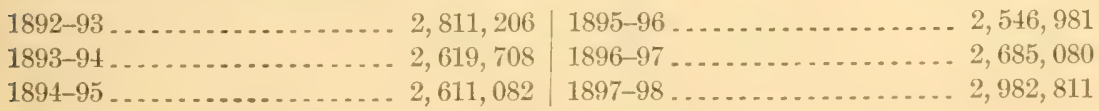

${ }^{1} \mathrm{~A}$ home authority estimates the Angoras in the State at $65,000$.

$11786-$ No. $27-01-6$ 
IN ANGORA VILAYET.

Schreiner estimated that the number of Angoras in the vilavet of Angora in 1894, was 1,230,000. He also directs attention to the fact that the mohair area of Turkey in Asia extends beyond that province.

\section{PRODUCTION OF MOHAIR.}

The quantity of mohair of all grades produced in the United States has beren a matter of guess, and the estimates have been wide apart. Assuming that practically the entire domestic product goes to the mills for fahrication, the Bureau addressed to the mills that consume mohair a request to be furnished a statement of the amount of domestic and imported mohair used ammually. It is believerl, therefore, that these statistics which are given herewith represent the total product of the United States for the year 1899:

Consumption of mohair in the United States in 1899.

\begin{tabular}{|c|c|c|}
\hline Mills. & Domestic. & Imported. \\
\hline . & Pounds. & Pounds. \\
\hline Sanford Mills and the Goodall Worsted Co., Sanford, Me ....... & 810,000 & 460,000 \\
\hline Tingue Manufacturing Co., Seymour, Conn............ & 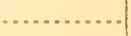 & 15,000 \\
\hline 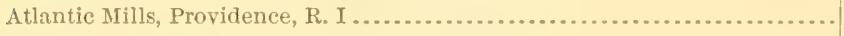 & & 1296,465 \\
\hline Gold Medal Braid Co., Attleboro Falls, Mass .......... & n........... & 1,000 \\
\hline Massachusetts Mohair Plush Co., Lowell, Mass........ & 200,000 & 300,000 \\
\hline Westfield Braid Co., Westfield, Mass............. & ......... & 18,000 \\
\hline Cranston Worsted Mills, Bristol, R. I .............. & 32,000 & 39,000 \\
\hline Queensbury Mills, Worcester, Mass.................................. & 5,000 & (............ \\
\hline Total. & $1,077,000$ & $1,119,465$ \\
\hline
\end{tabular}

${ }^{1}$ Not certain it was imported mohair, but assumed to be.

The customs figmes of the Cape of Good Hope, as quoted by IV. I Iammond 'Tooke, show that mohair was produced there for various years previous to 1898 in the following amounts:

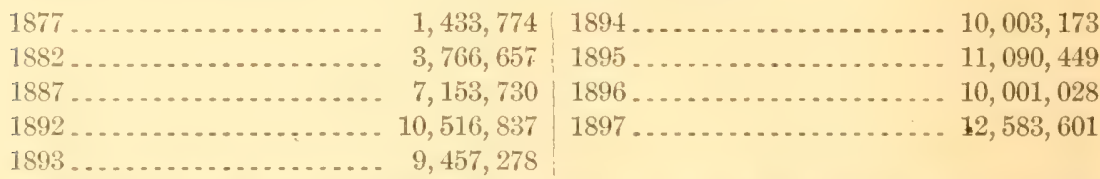

Aceording to Commercial Relations for 1s!n the entire product of the (ape of Good Hope for 1n:7 was exported, as well as that for 1898 , which is given as $10,876,014$ pounds.

It has not been posible to ohtain tigures showing the production of 'Turkey for any specific year or for a series of years, but the average annual production is frequently given as $7,650,000$ pounds.

TARIFF.

The act approved July 2t, 1897, places a duty of 12 cents per pound upon mohair. Mohair eloth for buttons is taxed 10 per cent ad 
valorem. The duty on dressed and finished goatskins is 20 per cent ad valorem; on skins for moroceo, tanned but unfinished, 10 per cent ad valorem. These rates are subject to increase under certain conditions of shipments.

\section{REGISTRATION ASSOCIATIONS.}

The Bailey Angora Goat Registration Association, of sim Jose, Cal., has kept a private register for many years, and became a general record association in 1898.

There are two registration associations in the United States which were organized during the year 1900-the American Angora Goat Breeders' Association, with headquarters at Kansas City, Mo., and the National Angora Record Association, with headquarter's at Salem, Oreg.

\section{LITERATURE CONSULTED.}

The principal works consulted in the preparation of this paper are as follows:

Schreiner, S. C. Cronwright:

The Angora Goat (published under the auspices of the South Afriean Angora Goat Breeders' Association). Longmans Green \& Co., London, New York, and Bombay. 1898. Pp. 256, figs. 22.

HAYES, JoHN L.:

The Angora Goat: Its Origin, Culture, and Products. Anerican Agriculturist, New York. 1882.

Hook, Bryan:

Milch Goats and their Management. Vinton \& Co., Limited, London. 1896. Pp. 115, figs. 17.

Hoerle, Gustav A.:

The Angora Goat: Its Habits and Culture. Fink \& Co., Leon Springs, Tex. 1886. Pp. 32.

Jobson, E. H.:

Angora Goat Raising. E. H. Jobson, Lake Valley, N. Mex. 1900. Pp. 29, fig. 1. Alten, George Edward:

Angora Goats: The Wealth of the Wilderness. Horace A. Field \& Co., Wellsboro, Pa. 1900. Pp. 32, fig. 1.

C. P. Bailey \& Sons Co.:

California Angoras. San Jose, Cal. 1900.

Besides these access has been had to hundreds of articles in the agricultural press. Special mention should be made of the Oregon Agriculturist, Portland, Oreg., the Pacific Rural Press, San Franciseo, Cal., and the American Sheep Breeder, Chicago, Ill. 'The two latter devote a page regularly to the goat industry.

The library force of the Bureau of Animal Industry have prepared a bibliography of goat literature, but the titles are so numerous that it has been deemed advisable to hold them for separate publication rather than to append them here. 



\section{N D EX.}

Age-

Page.

and blood, influence on fiber .............................. 39

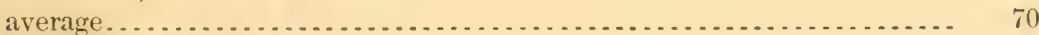

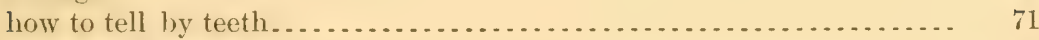

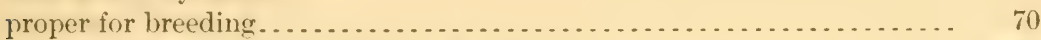

Agriculturist, Oregon, notes on the meat as food ..................... 48

Allen, Richard, remarks on history of importation into United Statex...... 14

American-

Angora Goat Breeders' Association ............................. 83

Institute, report of committee on examination . . . . . . . . . . . . . . 17

Angora-

city, geographical and historical notes............................ 12

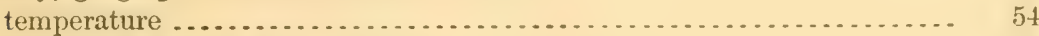

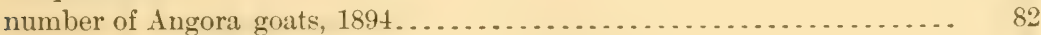

number of Angora goats, production of mohair, ete . . . . . . . . . . . . 38

Angora goats-

building up and management of flock ........................... 68

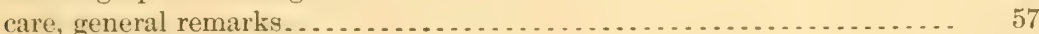

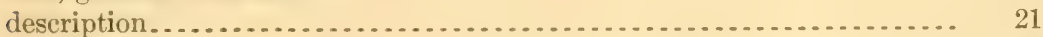

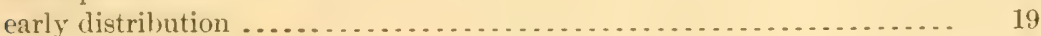

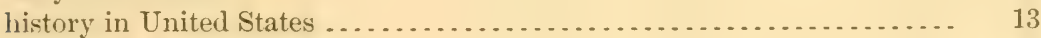

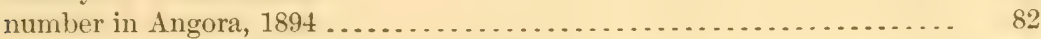

number in Angora and Cape of Good Hope ... . . . . . . . . . . . . . . . . 38

number in Cape of Good Hope, 1893-1898 . . . . . . . . . . . . . . . . . . . . 81

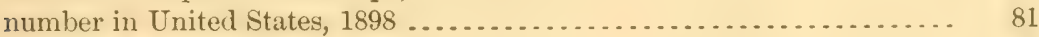

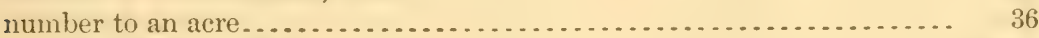

readily sold for meat .................................... 49,50

recent awakened interest. . . . . . . . . . . . . . . . . . . . . . . . . . 9

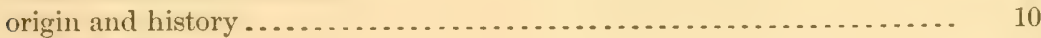

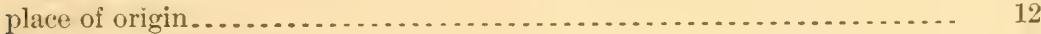

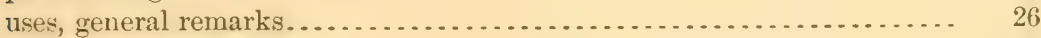

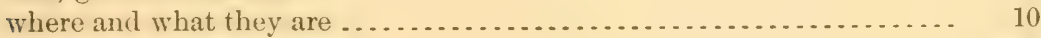

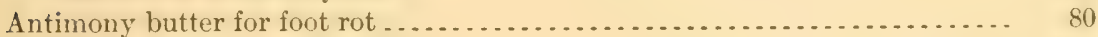

Ash in guats' and cows' milk ................................... 51

Asia Minor, different kinds of Angora goats . . . . . . . . . . . . . . . . . . . . 15

Bachman, John-

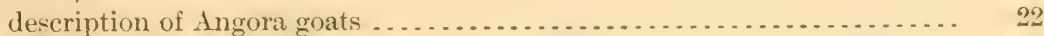

relation between mohair and climate of Angora................... 12

Bailey Angora Goat Registration Association ... . . . . . . . . . . . . . . . . . . 83

Bailey, C. P.-

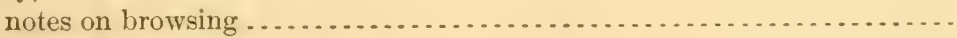

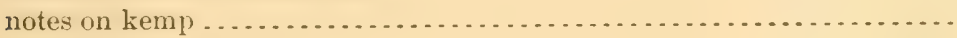


Bailey, C. P.-Continued. Page.

notes on sale for meat......................................... 50

notes on the meat as food .................................... 48

notes on weight and value of fleece ............................. 39

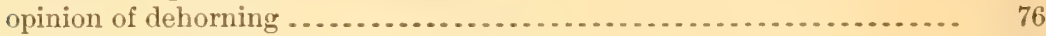

remarks on kemp.............................................. 40

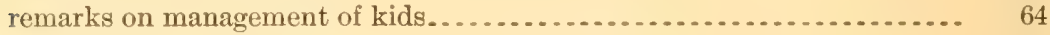

Barnes, Almont-

estimate of available land . ................................... 56

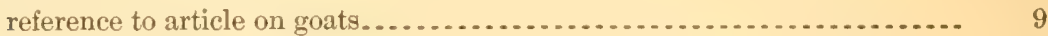

Barnette, Josephus R.-

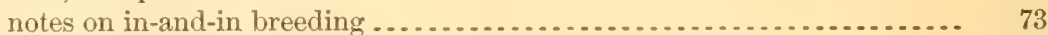

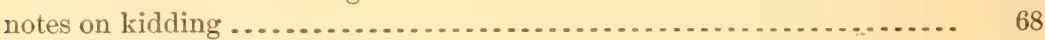

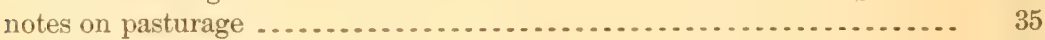

notes on sale for meat ...................................... 50

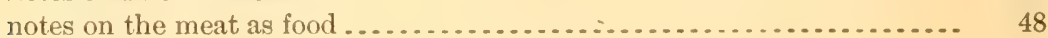

Beck, Q. M.-

notes on in-and-in breeding .................................. 73

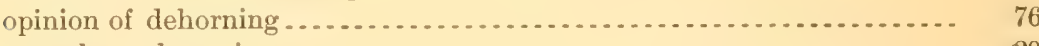

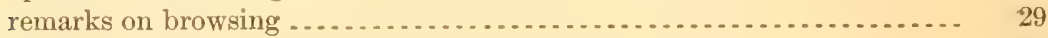

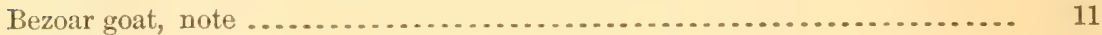

"Billy Atlanta" in California. . . . . . . . . . . . . . . . . . . . . . . . . . . . . . . . 19

Binns, Henry O.-

crossing of Angora and Kurd goats ............................

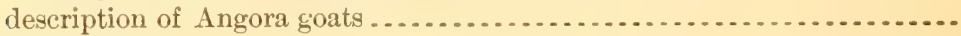

Black, William L。-

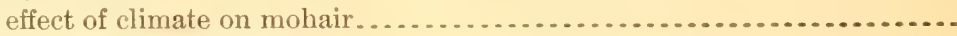

hornless Angora goats ... . . . . . . . . . . . . . . . . . . . . . . . . . . .

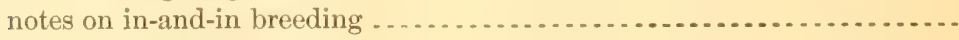

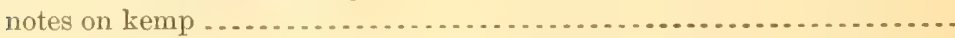

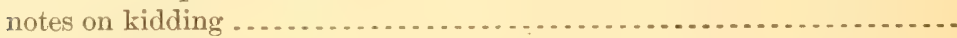

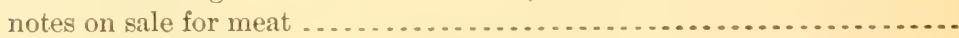

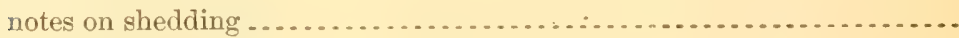

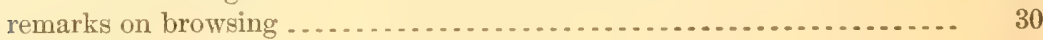

Blackburn, Abe-

notes on in-and-in breeding .................................. 73

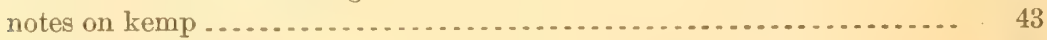

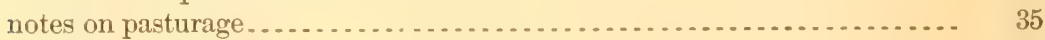

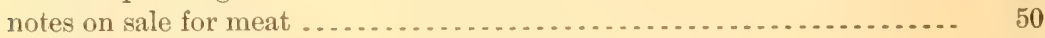

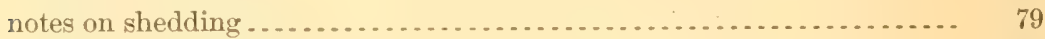

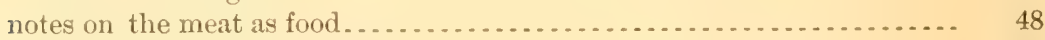

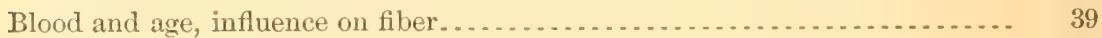

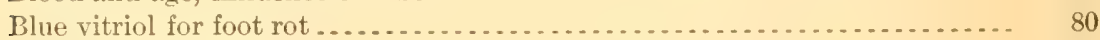

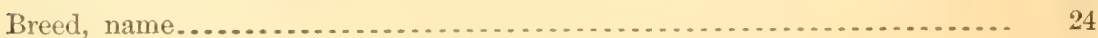

Breeding-

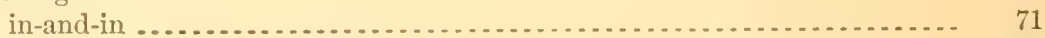

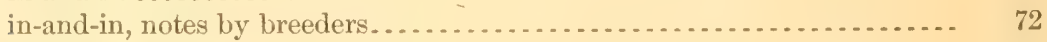

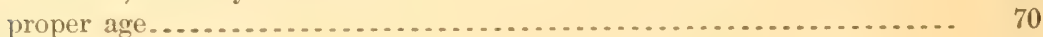

Brown, W. -

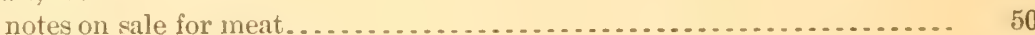

notes on the meat as food ....................................... 48

Browsing-

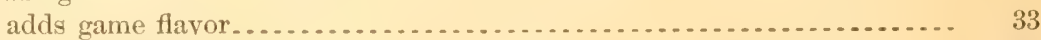

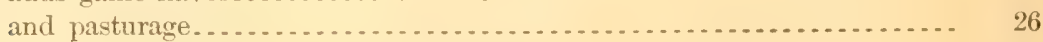

character furnished by different states . . . . . . . . . . . . . . . . . . . . 32 
Browsing-Continued.

notes by breeders

remarks by E. II, Jobson . . . . . . . . . . . . . . . . . . . . . .

remarks by H. T. Fuchs.................................

remarks by J. R. Ntandley . . . . . . . . . . . . . . . . . . . . . .

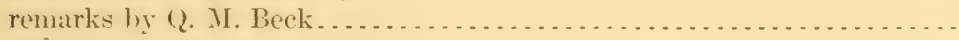

remarks by William $\mathrm{L}$. Black .............................

supplements feeding . . . . . . . . . . . . . . . . . . . . . . . . . .

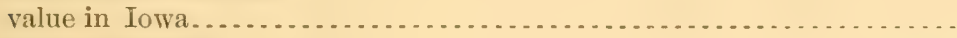

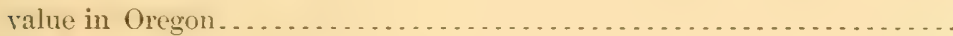

Brush-

destroyers, utility of common goats............................

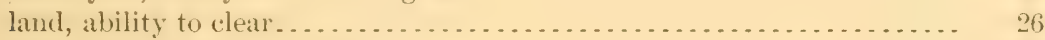

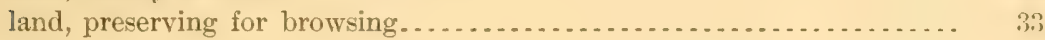

Buck-

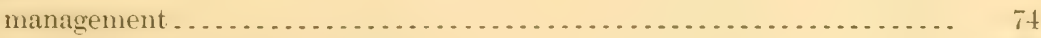

number of does he should serve ............................ it

service, remarks by G. A. Hoerle . . . . . . . . . . . . .

Butter-

fat in goats' and cows' milk................................... 51

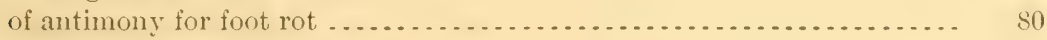

Cape of Good Hope-

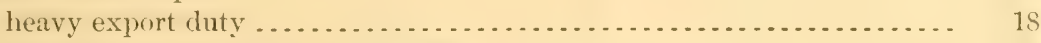

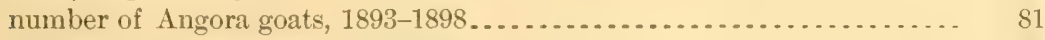

number of Angora goats, production of mohair, etc .............. is

production of mohair, $1877,1882,1887,1892-1897 \ldots \ldots \ldots \ldots \ldots \ldots \ldots . \quad 82$

temperature ......................................... 54

Capra segagrus-

description ............................................. 11

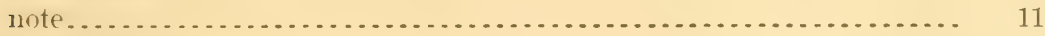

Capra falconeri-

description

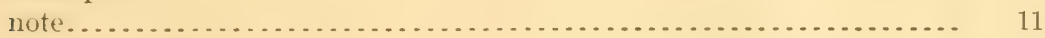

Capra hircus, note ................................................. 11

Casein in goats' and cows' milk .................................. 51

Cashmere goats, description by Israel S. Diehl ...................... 15

Castration of kids ........................................... $6 t^{3}$

Chenery, C. T., importer ..................................... 18

Chenery importation in California................................ 19

Cladek, V.-

notes on in-and-in breeding............................... 7

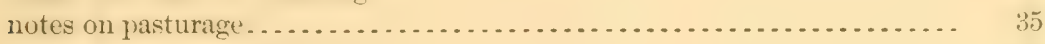

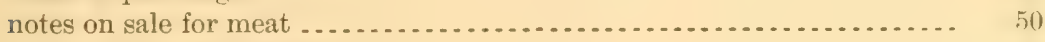

notes on the meat as food .................................. ts

Climate-

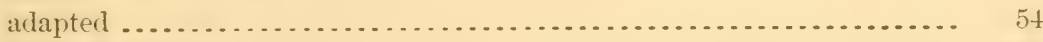

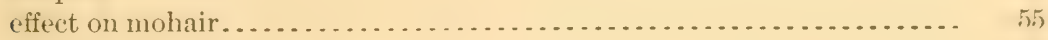

Clipping machine for shearing goats ..............................

Conklin Bros.-
notes on in-and-in breeting $\ldots \ldots \ldots \ldots \ldots \ldots \ldots \ldots \ldots \ldots \ldots \ldots \ldots$

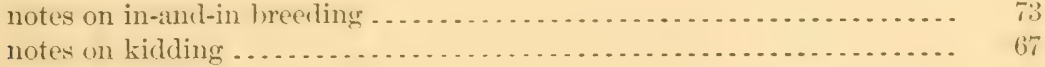

notes on sale for meat .................................. 50

Cook \& Buck-

notes on pasturage. . . . . . .

notes on the meat as food................................. ts 
Copper sulphate for foot rot.

Cow's ond goats' milk,

Cranston Worsted Mills, mohair consumed, 1899... . . . . . . . . . . . . $\quad 82$

Cumberbatch, H. A., elimate of Angora vilayet . . . . . . . . . . . . . . . . 12

Davis, James B.-

appointment as cotton expert for Turkey ....................

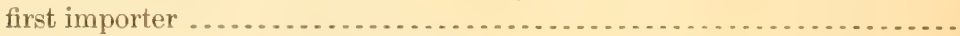

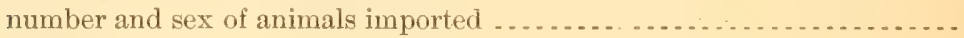

Dehorning . . . . . . . . . . . . . . . . . . . . . . . . . . . . . . .

Diehl \& Brown-

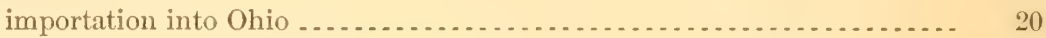

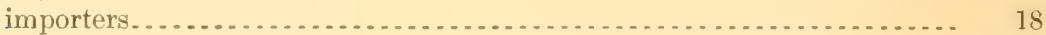

Diehl, Israel S.-

description of Angora goats

15,22

different kinds of Angora goats in Asia Minor ................... 15

investigation of mohair industry in Angora..................... 21

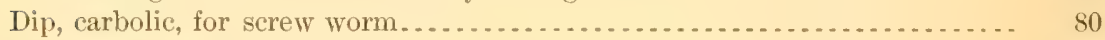

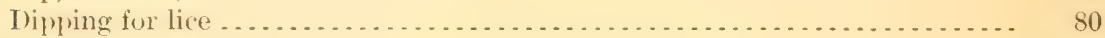

Diseases and other enemies................................... 79

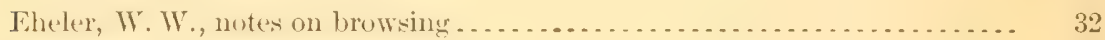

Enemies . . . . . . . . . . . . . . . . . . . . . . . . . . . . . . . . . . . 79

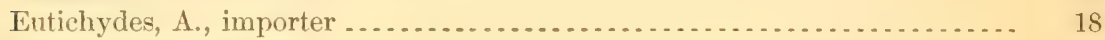

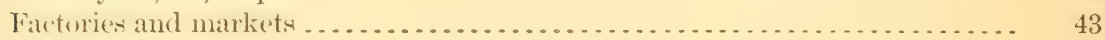

Feeding-

general remarks. . . . . . . . . . . . . . . . . . . . . . . . . . . .

fistidiousness of goats . . . . . . . . . . . . . . . . . . . . . . . . . . . 61

in winter, notes by breeders.................................. 61

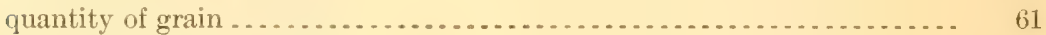

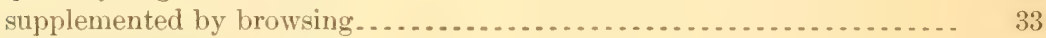

Fence, suitable kind . . . . . . . . . . . . . . . . . . . . . . . . . . . 58

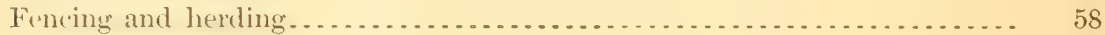

Fiber-

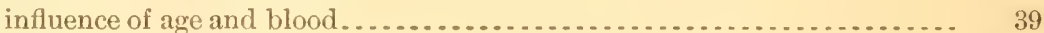

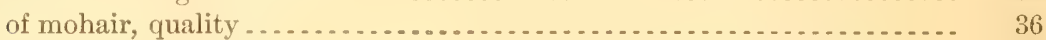

Fink, Henry-

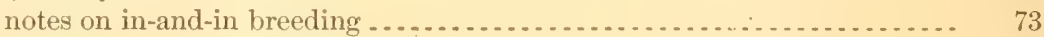

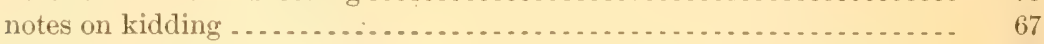

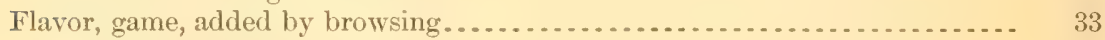

Fleece-

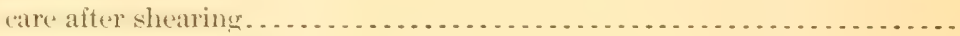

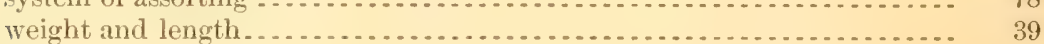

Flock-

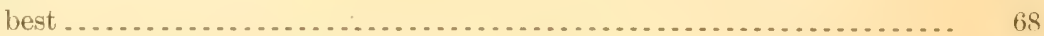

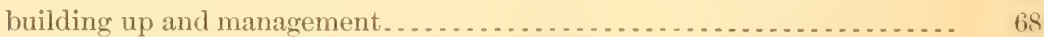

building up by crossing upon common goat ..................

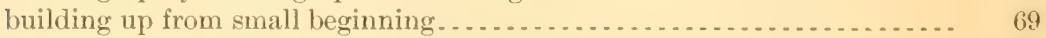

building up, remarks by G. A. Hoerle . . . . . . . . . . . . . . . . . . 70

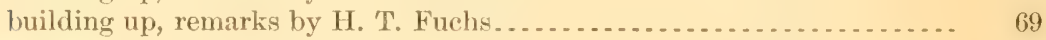

Flocks, size . . . . . . . . . . . . . . . . . . . . . . . . . . . . . . . . . . . 75

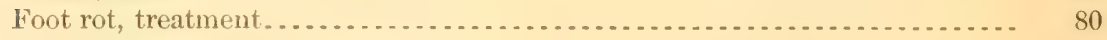

Fuchs, H. T.-

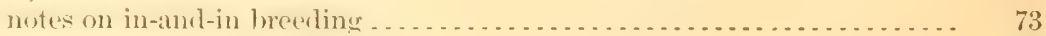

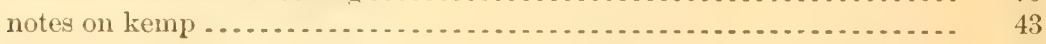


Fuchs, H. T.-Continued.

notes on kidding .

notes on pasturage.

notes on sale for meat.

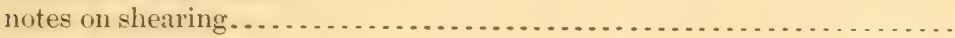

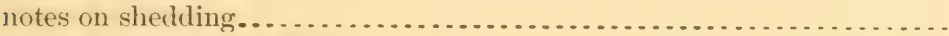

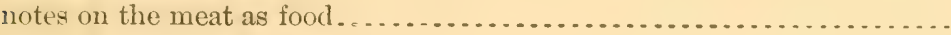

notes on trapping wolves.

remarks on browsing .

remarks on building up flock................................. 69

remarks on protection to sheep by goats ......................... 53

Game flavor added by browsing ..................................... 33

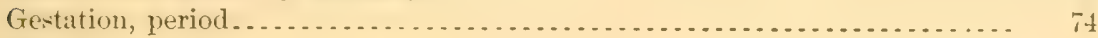

Goats-

and cows' milk, comparison.

Angora. (See Angora goats.)

common, as brush destroyer.

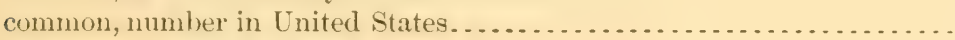

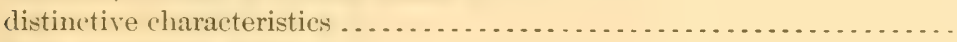

wild, number of species. . . . . . . . . . . . . . . . . . . . . . . . . . .

Gold Medal Braid Co., mohair consumed, $1899 \ldots \ldots . . . . . . . . . . . . . . . .$.

Goodall, George B.-

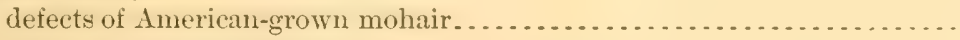

notes on handling fleeces . . . . . . . . . . . . . . . . . . . . . . . . .

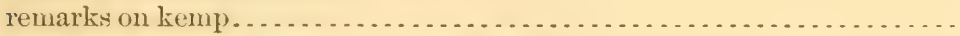

Goodall Worsted Co., mohair consumed, 1899......................

Grant, U.S.-

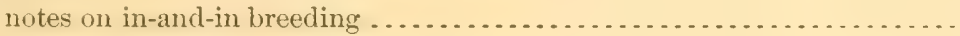

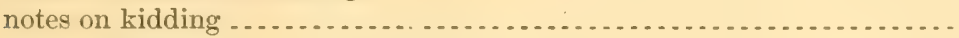

notes on pasturage........

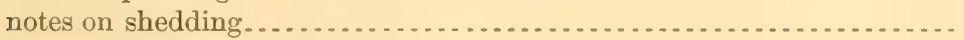

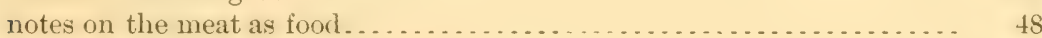

Grass and weeds as pasturage ... . . . . . . . . . . . . . . . . . . . . . .

Hair of goats spun by Israelites . . . . . . . . . . . . . . . . . . . . . . . . . 12

Harris \& Baylor-

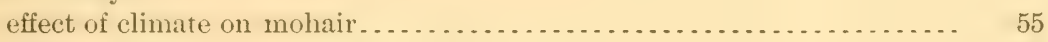

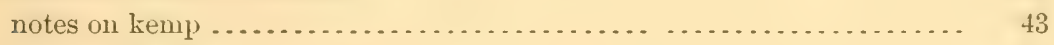

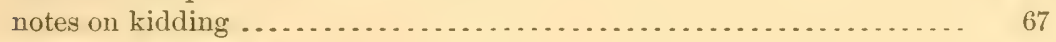

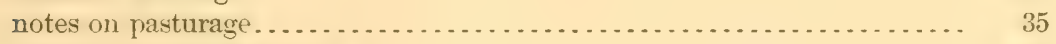

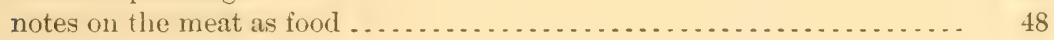

Harris, John S.-

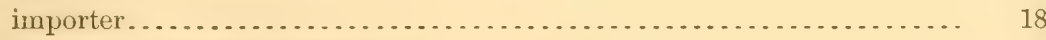

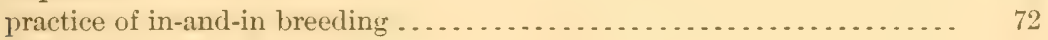

Hayes, John L.-

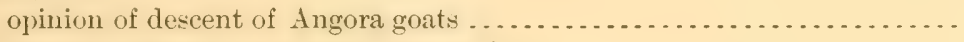

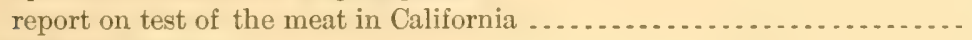

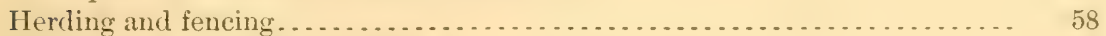

Hinkle, E. A., uotes on shedding. . . . . . . . . . . . . . . . . . . . . . . . . . 79

History-

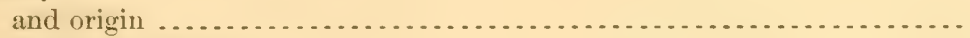

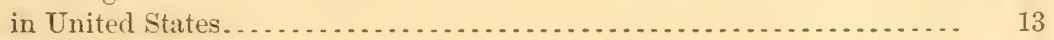

Hoag, J. Murray-

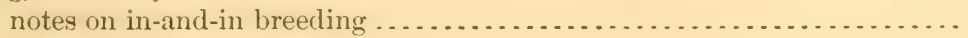

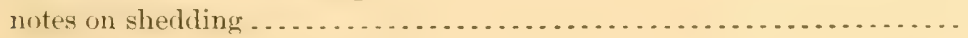


Hoerle, Gustav A.-

Page.

description of Angora goats ................................ 23

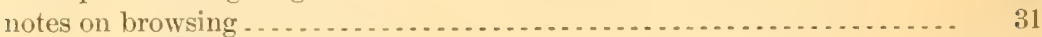

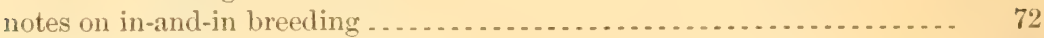

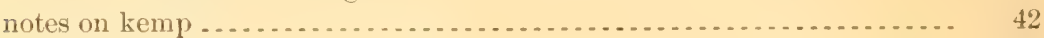

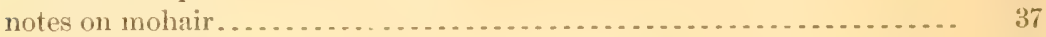

notes on pasturage....

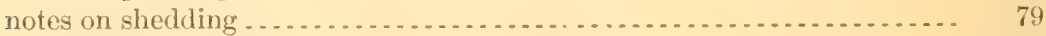

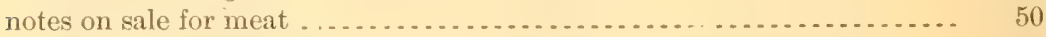

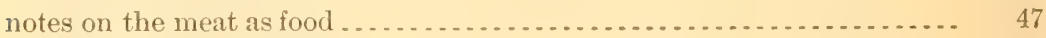

quantity of grain to feed . . . . . . . . . . . .

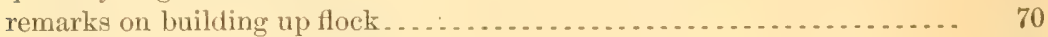

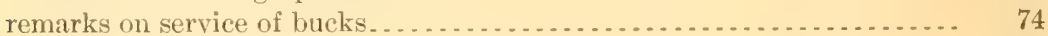

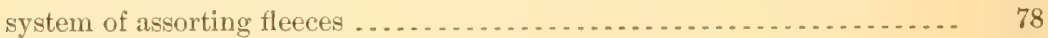

Hollings, S. B., notes on mohair . . . . . . . . . . . . . . . . . . . . . . 37

Hook, Bryan, remarks on fastidiousness of goats . . . . . . . . . . . . . . . . 61

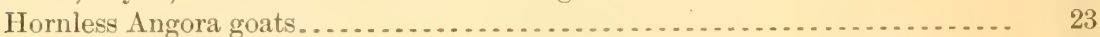

"Hornless Johnnie," note by W. M. Landrum ........................ 23

Houck, George A.-

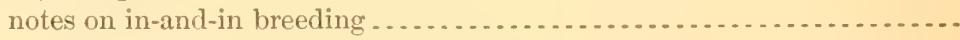

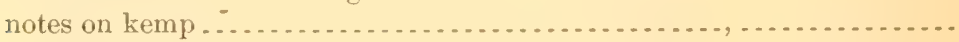

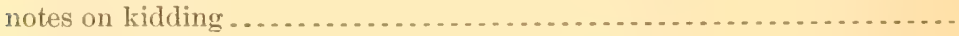

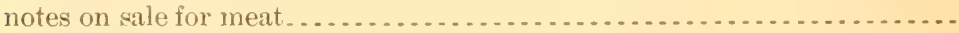

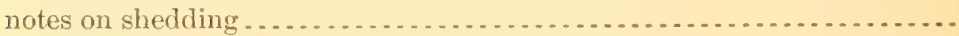

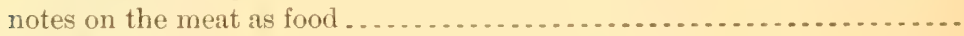

Hughes, W. G., \& Co.-

method of separating kids and does . . . . . . . . . . . . . . . . . . . . .

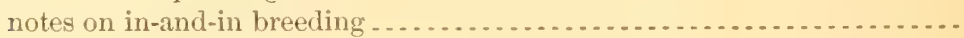

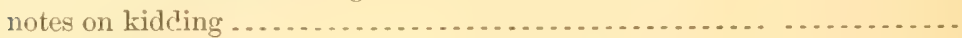

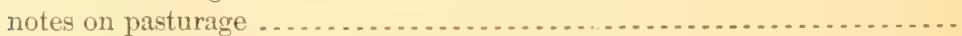

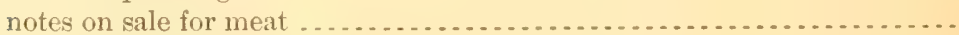

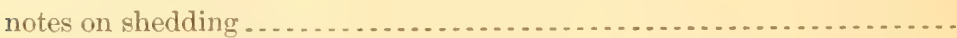

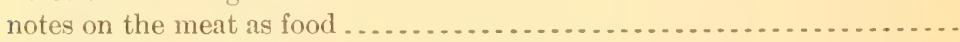

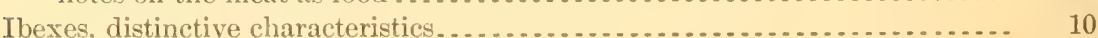

In-and-in breeding-

general remarks.

Jobson, E. H.-

notes on in-and-in breeding ... . . . . . . . . . . . . . . . . . . .

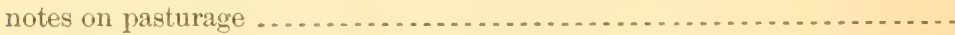

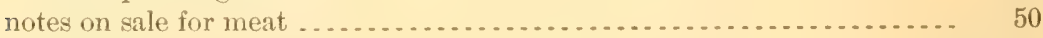

notes on the meat as food . . . . . . . . . . . . . . . . . . . . . . . . . 46, 47, 48

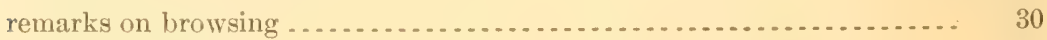

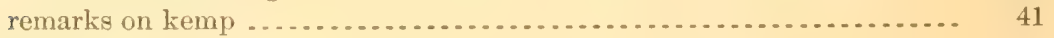

Johnston, R. C.-

notes on browsing .......................................... 32

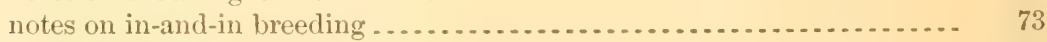

notes on sale for meat ...................................... 50

notes on the meat as food . .................................... 48

Kemp-

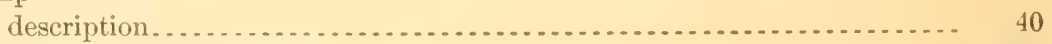

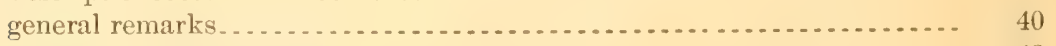

remarks by breeders. . . . . . . . . . . . . .

remarks by C. P. Bailey . ......................................... 40

remarks by E. H. Jobson.... . . . . . . . . . . . . . . . . . . . . . . . . 41 
Kidding-

Page.

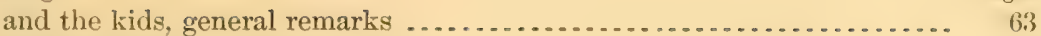

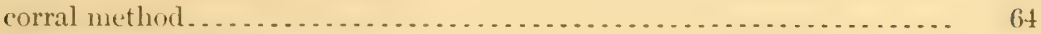

Mexican method of management...................................

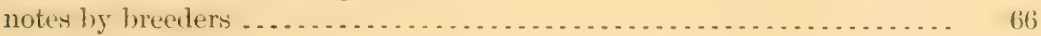

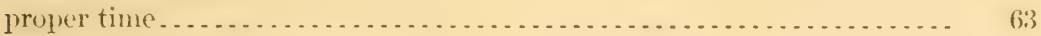

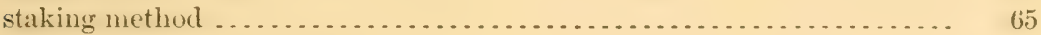

Kids-

and kidding, general remarks .................................. 63

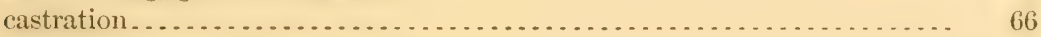

number dropped by one doe ... . . . . . . . . . . . . . . . . . . . . . 75

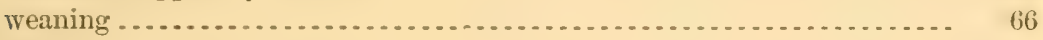

Kimball, H. 1.-

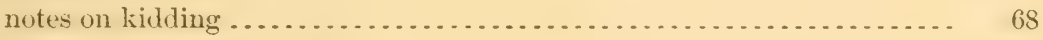

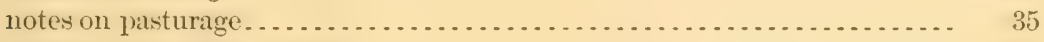

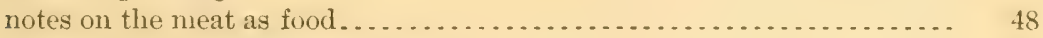

notes on use of clipping machines ............................

Kurd goat, crossing with Angora goats in Angora.................... 21

Land-

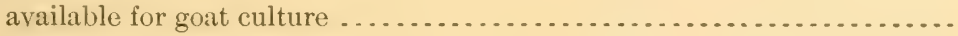

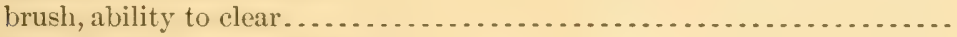

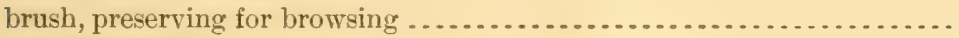

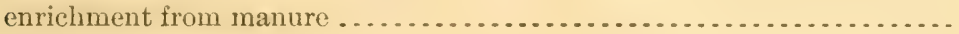

Landrum, F. O.-

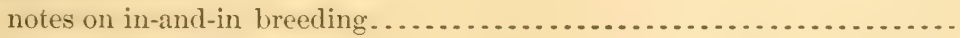

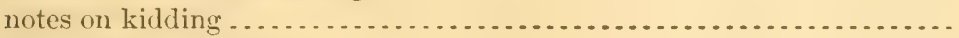

Landrum, William M. -

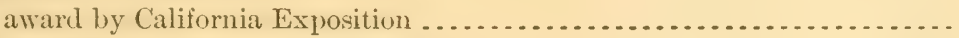

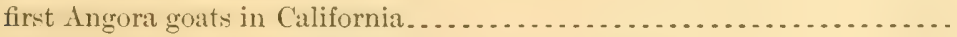

first to discover that so-called Cashmere was Angora.................

remarks on temperature withstood by goats........................

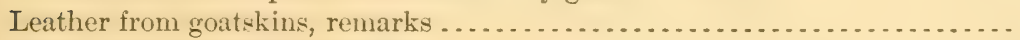

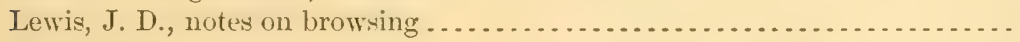

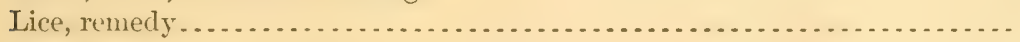

Localities adapted. . . . . . . . . . . . . . . . . . . . . . . . . . . . . . . . .

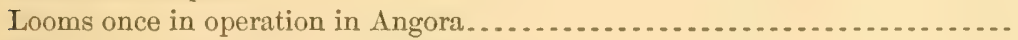

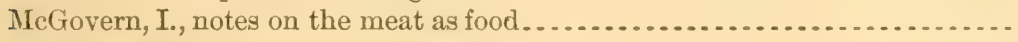

McIntire, W. T.-

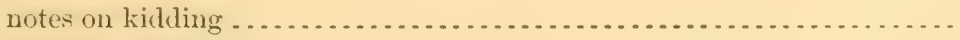

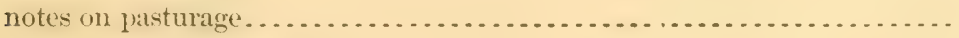

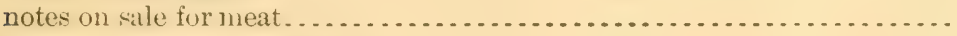

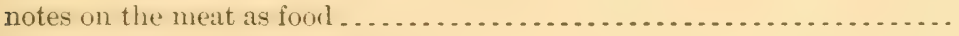

Machine, clipping, for shearing goats ............................. it

Manufactures-

of mohair, general remarks................................ 4

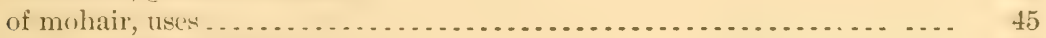

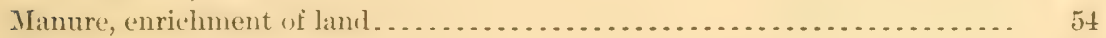

Markets-

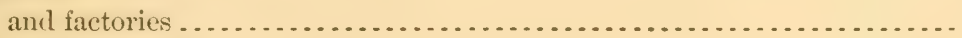

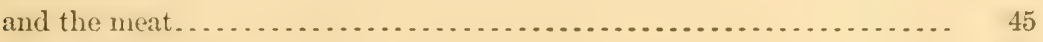

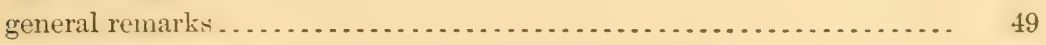

Marking, general remarks.................................. 62

Massachusetts Mohair Plush Company, mohair consumed, 1899........... 82

Mastin, Thomas H., notes on sale for meat...................... 50 
Meat-

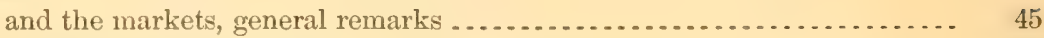

as food, notes by breeders..................................... 47

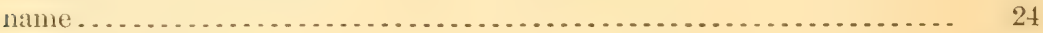

tests in California .......................................... 46

Milk-

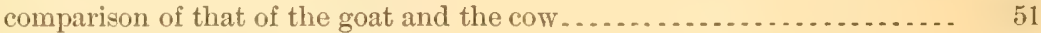

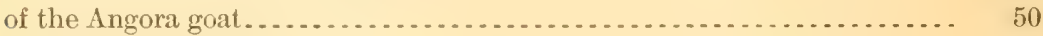

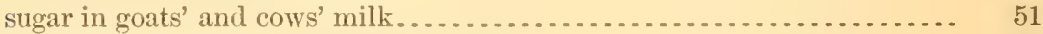

Miller \& Sibley, notes on the meat as food......................... 47

Miller, G. B., notes on in-and-in breeding ........................ 73

Mohair-

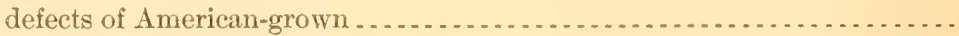

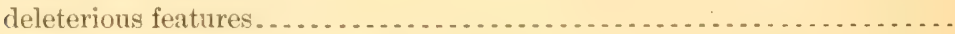

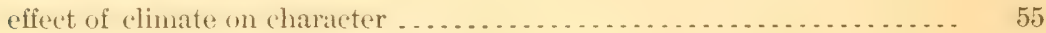

from United States in Bradford market ........................ 37

how separated from kemp ............................... 41

imported, amount manufactured in United States, $1899 \ldots . . . . . . . . .882$

manufactures, general remarks ........................... 44

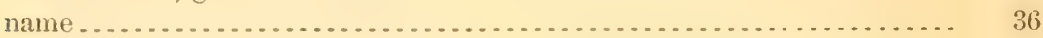

production in Cape of Good Hope, 1877, 1882, 1887, 1892-1897 ......... 82

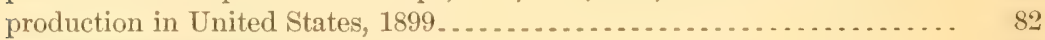

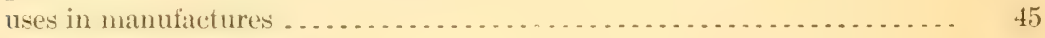

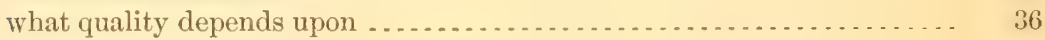

National Angora Record Association ............................. 83

New York State fair, report on examination...................... 17

Noilage, meaning of term.................................... +1

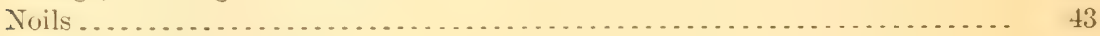

Odor of bucks and fleece........................................ 24

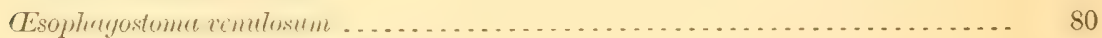

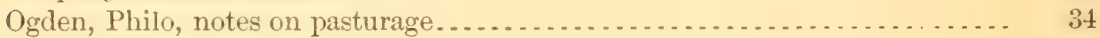

Oregon Agriculturist, notes on the meat as food .................. 48

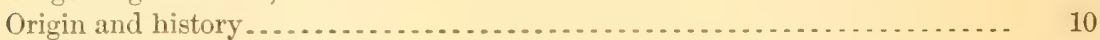

Parasites..................................................... 80

Pasturage-

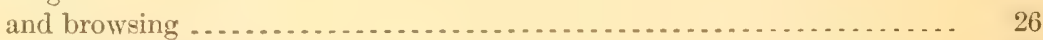

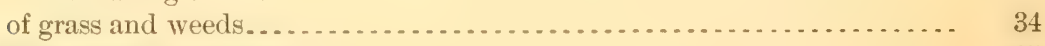

Pasturing with other stock. . . . . . . . . . . . . . . 35

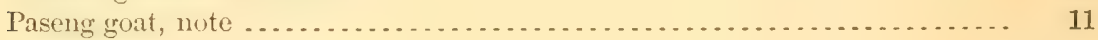

Pashum-

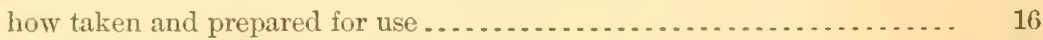

under coat of Cashmere.................................... 16

Payne, William R.-

manufactures of mohair................................ 45

uses of Angora skins. . . . . . . . . . . . . . . . . . . . .

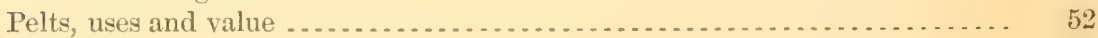

Pens and shelter, general remarks................................ 59

Peters, Richard-

award at United States Agricultural Society ................... 16

founder of industry in United State's .......................... 18

importation from Asia Minor................................ 18

purchase of Davis importation in 1853 ........................ 17 
Pets, use of Angora goats.

Page.

Plants joisonous to groats

Pneumnnia, verminous

Porter, George A., note on Davis importation .

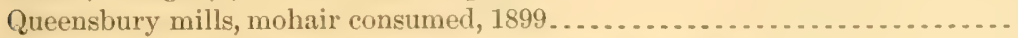

Queensland Agricultural Journal, notes on the meat as food .............. .

Rexistration associations . . . . . . . . . . . . . . . . . . . . . . . . . . 10,

Richardson Brothers-

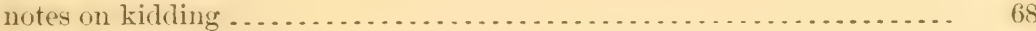

notes on sale for meat........................................ 50

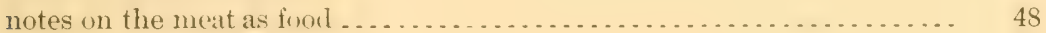

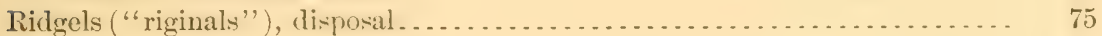

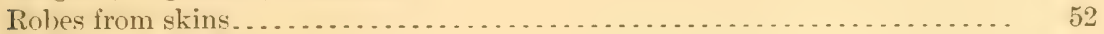

Round worms affecting . . . . . . . . . . . . . . . . . .

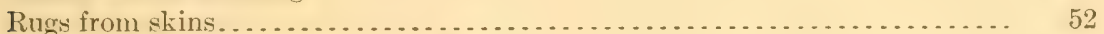

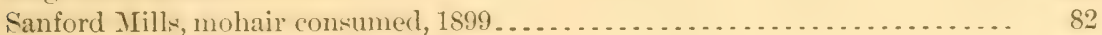

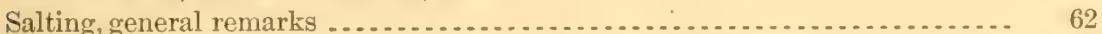

Seab parasites.................................................. 80

Schreiner, S. C. Cronwright-

description of Angora goats................................... 22

opinion of descent of Angora goat

Sclerostomu Tiypostomum ..................................... 80

Scott, G. M. -

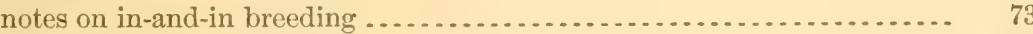

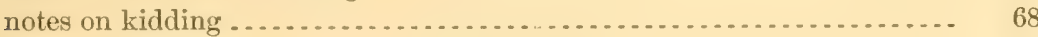

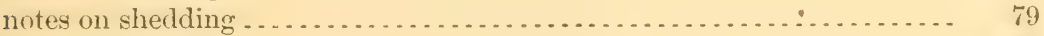

Screw worm, treatment ........................................... 80

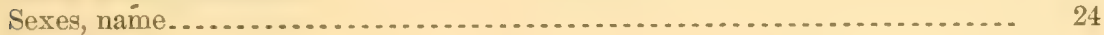

Shearing-

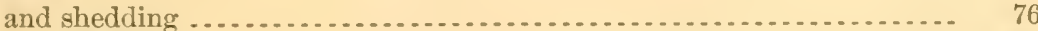

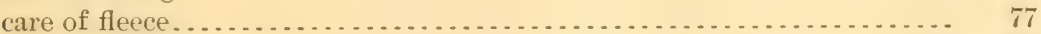

once or twice a year ............................................. 76

use of clipping machines..................................

Shedding-

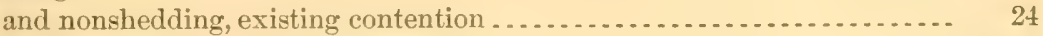

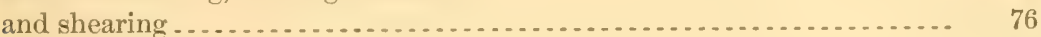

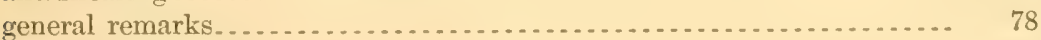

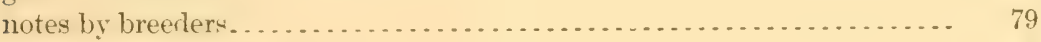

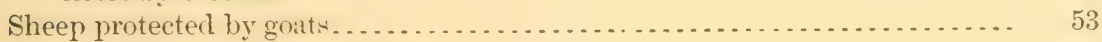

Shelter and pens, general remarks .................................. 59

Skins-

for robes, rugs, and trimmings. ............................... 52

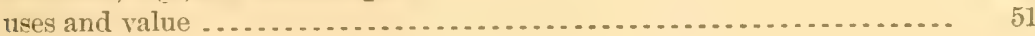

Smith, W. W.-

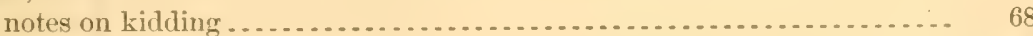

notes on in-and-in breeding......................................

Soil, character adapted............................................. 56

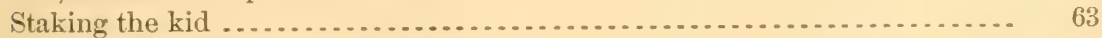

Standley, J. R.-

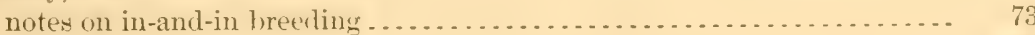

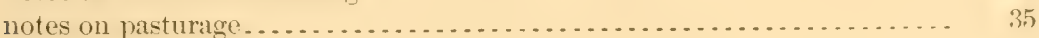

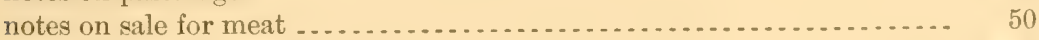

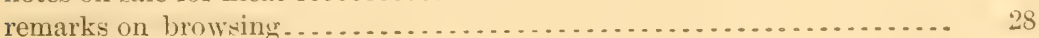


Stomach worm, treatment as for sheep............................. 80

Strongylus contortus, treatment as for sheep ........................ 80

Strongylus filicollis ................................................ $s 0$

Sulphate of copper for foot rot ................................. 80

Tapeworms, kinds affecting ....................................... 80

Tariff on mohair ...................................................... 82

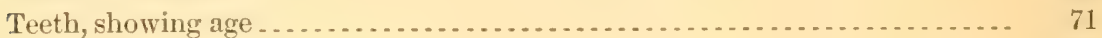

Temperature adapted................................................ 54

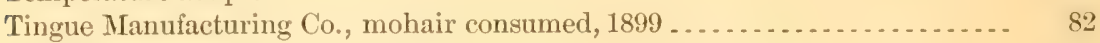

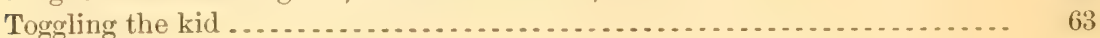

Tom, Oscar-

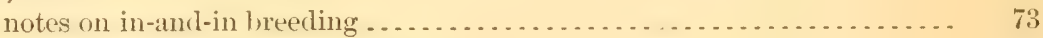

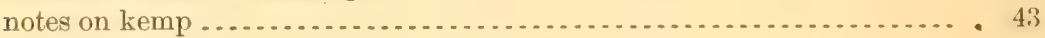

notes on kidding ............................................... 67

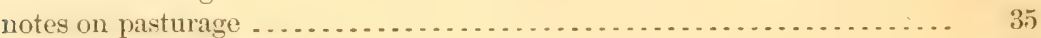

notes on sale for meat .......................................... 50

notes on the meat as food ..................................... 48

remedy for foot rot ........................................ 80

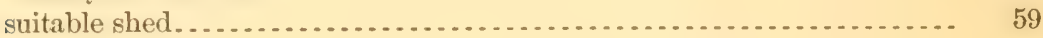

Tooke, W. Hammond-

number of Angora goats in Cape of Good Hope, 1893-1898 . . . . . . . . ... 81

remarks on suitable land in United States....................... 57

statement of production of mohair in ('ape of Good Hope, 1877, 185:2, 1887,

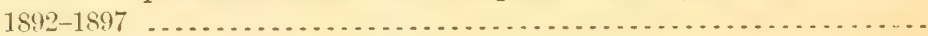

United States as competitor of Cape of Good Hope .................

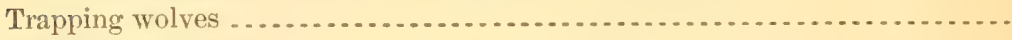

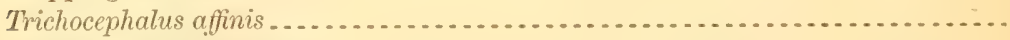

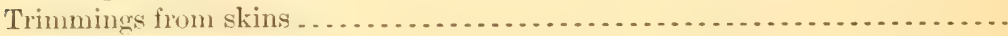

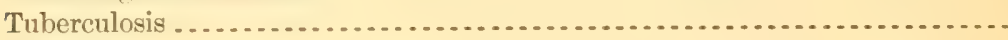

Turkey-

production of mohair .......................................

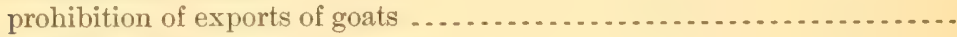

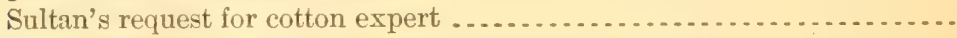

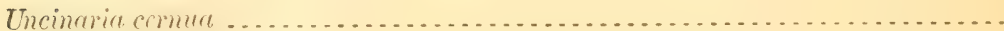

United States $A$ gricultural Society, award to Richard Peters..............

Verminous pneumonia ...........................................

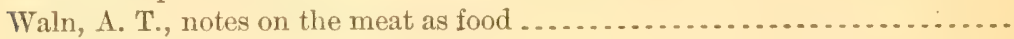

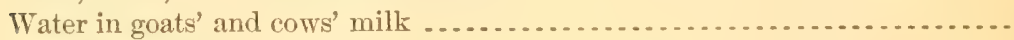

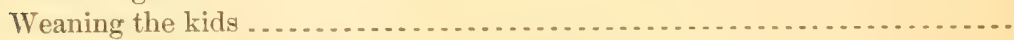

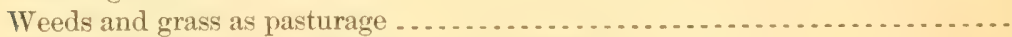

Westfield Brail (\%, mohair consumed, 1899 . . . . . . . . . . . . . . . . . .

Weyand, Julins, report on industry in California . . . . . . . . . . . . . . .

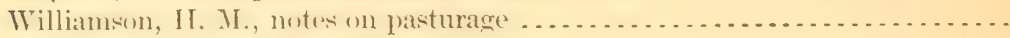

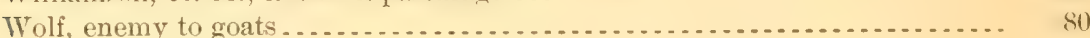

Worm-

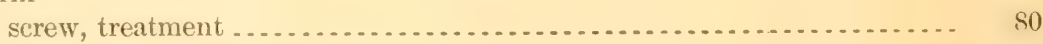

stomach, treatment as for sheep ............................... so

Worms, round, affecting .............................................. 80 

11 







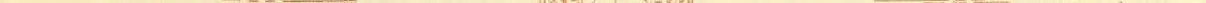


SMITHSONIAN INSTITUTION LIBRARIES 